\title{
USE OF DYE TRACING IN WATER- RESOURCES INVESTIGATIONS IN WYOMING, 1967-94
}

By James F. Wilson, Jr. and James G. Rankl

\section{U.S. GEOLOGICAL SURVEY \\ Water-Resources Investigations Report 96-4122}

Cheyenne, Wyoming 


\section{U.S. DEPARTMENT OF THE INTERIOR BRUCE BABBITT, Secretary}

U.S. GEOLOGICAL SURVEY GORDON P. EATON, Director

For additional information write to:

District Chief

U.S. Geological Survey, WRD

2617 E. Lincolnway, Suite B

Cheyenne, Wyoming 82001-5662
Copies of this report can be purchased from:

U.S. Geological Survey

Branch of Information Services

Box 25286, Denver Federal Center

Denver, Colorado 80225 


\section{CONTENTS}

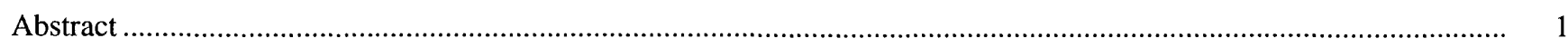

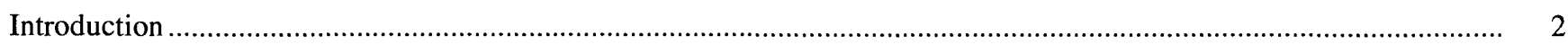

Chronology of dye tracing in water-resources investigations in Wyoming .......................................................

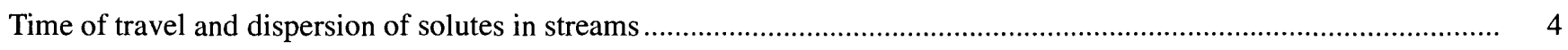

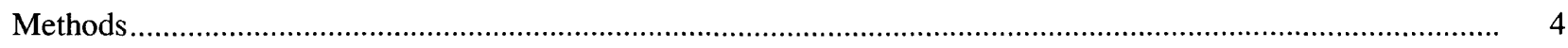

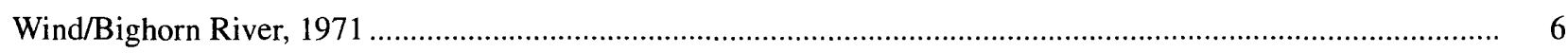

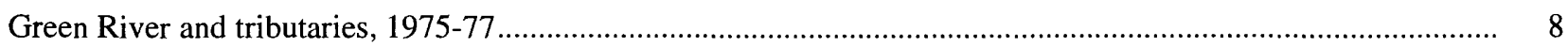

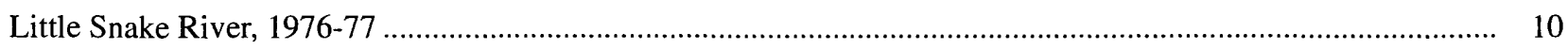

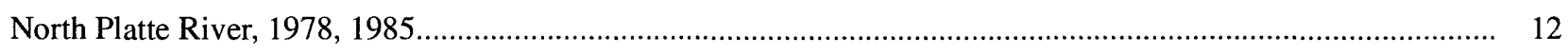

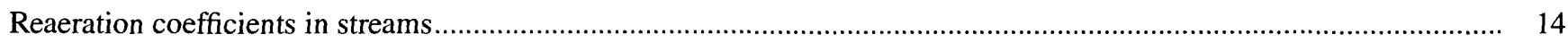

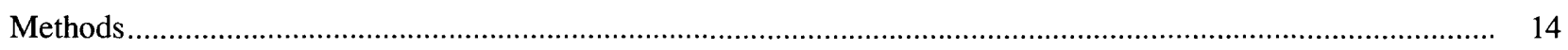

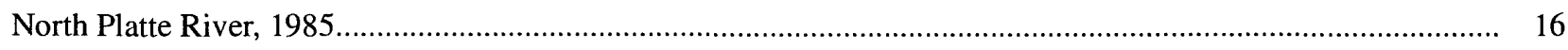

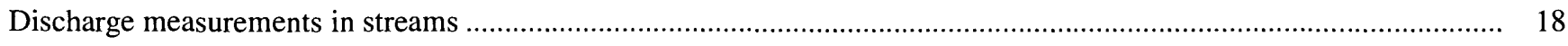

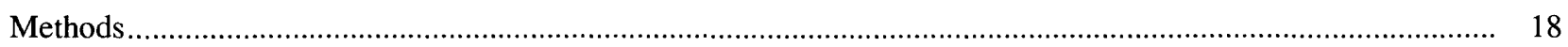

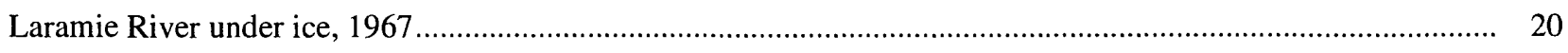

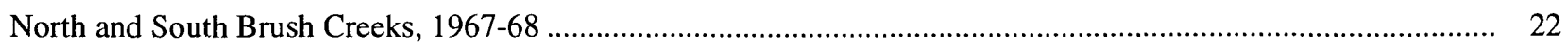

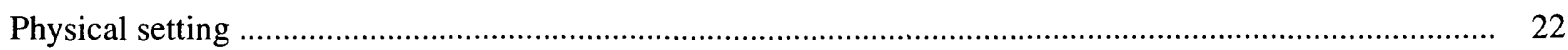

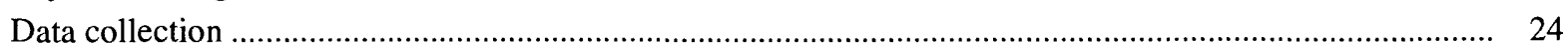

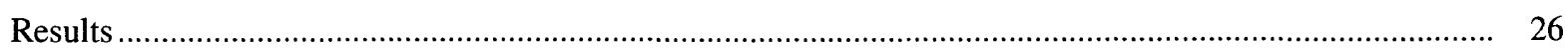

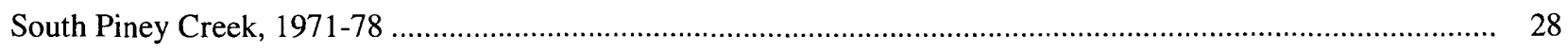

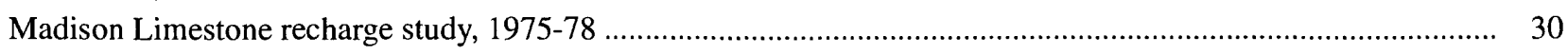

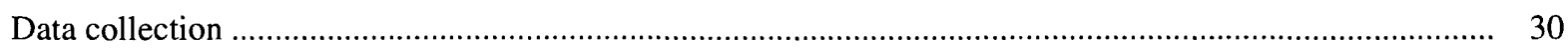

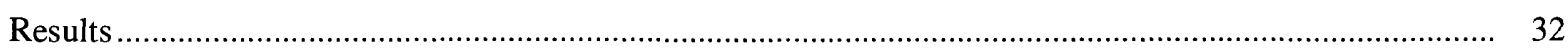

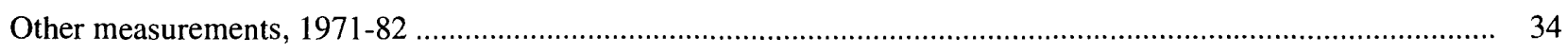

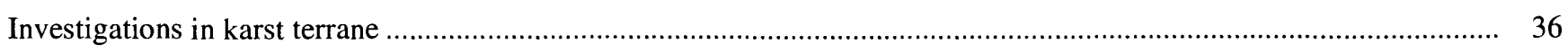

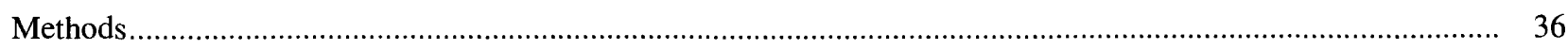

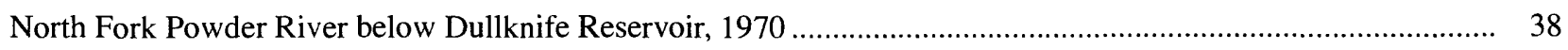

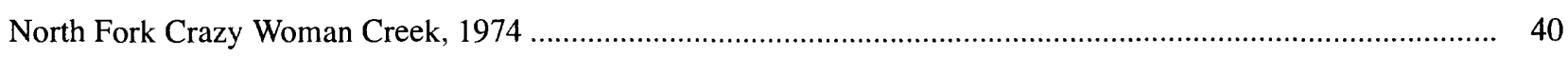

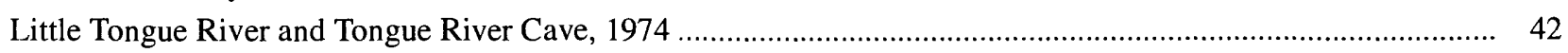

Middle Popo Agie River in Sinks Canyon State Park, 1983 ................................................................ 44

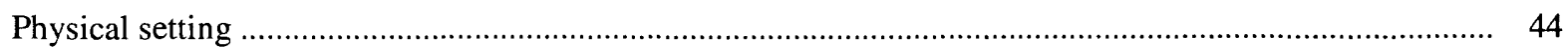

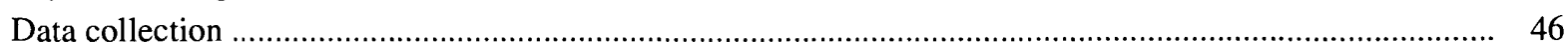

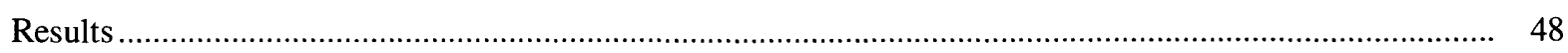

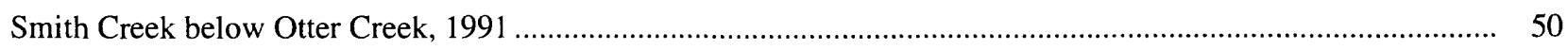

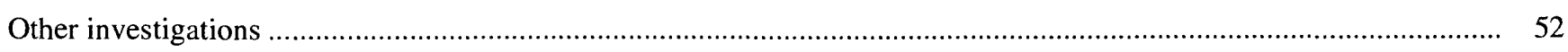

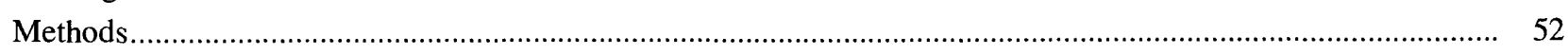

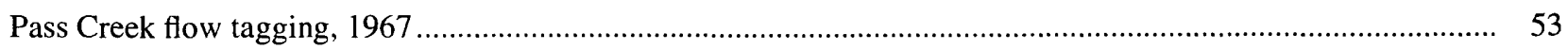

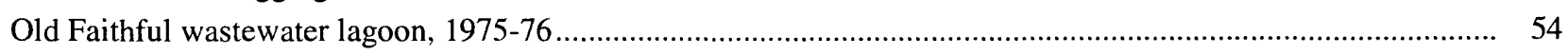

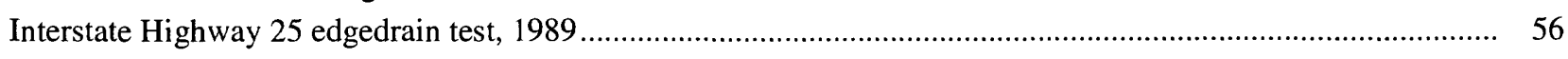

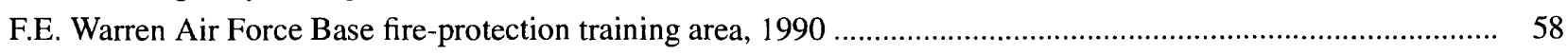

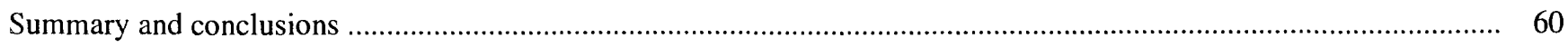

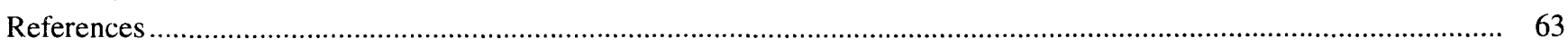


1. Typical response curve (concentration-time curve) at a point downstream from slug injection of a solute, such as a tracer dye

2. Example of dye-response curves at several sampling sites for a single injection of dye, Wind/Bighorn River, March 1971

3. Example of graphical relation of time of travel to distance traveled, Wind/Bighorn River, 1971

4. Map showing location of streamflow-gaging stations and dye-injection and sampling sites, Wind/Bighorn River

5. Graph showing relation of time of travel to water discharge, Wind/Bighorn River

6. Map showing location of streamflow-gaging stations and dye-injection and sampling sites, Green River, East Fork River, Big Sandy River, Horse Creek, and Blacks Fork

. Graph showing relation of mean velocity to water discharge at two streamflow-gaging stations and in a 70.3-mile reach, Green River downstream from Fontenelle Reservoir

Map showing location of streamflow-gaging stations and dye-injection and sampling sites, Little Snake River

9. Graph showing relation of time of travel to water discharge at streamflow-gaging station 09257000 , Little Snake River near Dixon, Wyoming

10. Map showing location of streamflow-gaging stations and dye-injection and sampling sites, North Platte River

11-13. Graphs showing:

11. Velocity-discharge relations for leading edge and peak concentration of dye cloud, North Platte River between Casper and Orin, Wyoming.

12. Relation between passage time of dye cloud and distance downstream from the point of injection, North Platte River between Casper and Orin, Wyoming

13. Relation between unit-peak concentration and time of travel of peak, North Platte River between Casper and Orin, Wyoming.

14. Map showing location of dye- and gas-injection sites and sampling sites, and subreaches for which reaeration coefficients were calculated, North Platte River

15. Dye-response curves in North Platte River at Bryon Stock Trail bridge, October 9, 1985.

16. Gas-response curve in North Platte River at Bryon Stock Trail bridge, October 9, 1985.

17. Dye-response curve for a constant-rate injection of dye

18. Diagram of injection equipment and stream reach for a dye-dilution discharge measurement ..........................

19. Graphs showing degrees of lateral mixing for dye-dilution discharge measurements.

20. Sketch of the test reach for dye-dilution discharge measurements under ice, Laramie River

21. Longitudinal section showing setup for injecting dye through ice, Laramie River.

22. Map showing location of streamflow-gaging stations on North and South Brush Creeks..

23. Typical cross section of channel of North Brush Creek

24. Typical cross section of channel of South Brush Creek

25. Sketch of dye-injection equipment used for high-flow discharge measurements in North Brush Creek

26. Dye-response curve for dye-dilution discharge measurement of October 6, 1967 in North Brush Creek

27. Dye-response curve for dye-dilution discharge measurement of October 6, 1967 in South Brush Creek

28. Graph showing stage-discharge relation for streamflow-gaging station 06622700, North Brush Creek near Saratoga, Wyoming.

29. Graph showing stage-discharge relation for streamflow-gaging station 06622900, South Brush Creek near Saratoga, Wyoming

30. Map showing location of streamflow-gaging station 06321000, South Piney Creek near Story, Wyoming.........

31. Graph showing stage-discharge relation for streamflow-gaging station 06321000, South Piney Creek near Story, Wyoming 
32. Map showing location of streamflow-gaging stations and miscellaneous-measurement sites used for the Madison Limestone recharge study and at which dye-dilution discharge measurements were made during 1975-78.

33. Graph showing stage-discharge relation for streamflow-gaging station 06297480, Tongue River at Tongue Canyon Campground, near Dayton, Wyoming

34. Map showing location of sites where miscellaneous dye-dilution discharge measurements were made, 1971-82.

35. Generalized stratigraphic chart of formations of Paleozoic age in parts of Wyoming where dye tests were conducted in karst terrane

36. Map showing location of dye-injection and sampling sites, North Fork Powder River.

37. Hydrographs of flow into sinkholes near Bull Creek and flow from large spring below Johnson Creek, North Fork Powder River downstream from Dullknife Reservoir, November 4-6, 1970

38. Dye-response curve in North Fork Powder River at large spring downstream from Dullknife Reservoir, November 4-6, 1970

39. Map showing location of streamflow-gaging stations and dye-injection and sampling sites, North Fork Crazy Woman Creek

40. Map showing location of streamflow-gaging stations, dye-injection site in the Little Tongue River, and dye-sampling site in Tongue River Cave

41. Dye-response curve in Cave Creek in Tongue River Cave, October 30-November 2, 1974 .............................

42. Map showing location of the Sinks and the Rise, Sinks Canyon State Park

43. Flow-duration curve for streamflow-gaging station 06231600, Middle Popo Agie River below the Sinks, near Lander, Wyoming, water years 1960-68

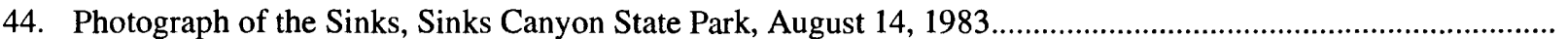

45. Photograph of the Rise, Sinks Canyon State Park, August 14, 1983 ...............................................................

46. Dye-response curves in Middle Popo Agie River at the Rise, Sinks Canyon State Park, August 14, 1983 .........

47. Map showing location of streamflow-gaging stations and dye-injection and sampling sites, Smith Creek study area

48. Graph showing monthly mean discharge at streamflow-gaging station 06645166, Smith Creek below Otter Creek, near Casper, Wyoming, water years 1988-91.

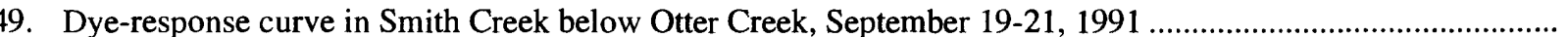

50. Map showing location of study reach of Pass Creek.

51. Map showing location of well OF2 and stream-sampling sites near the Old Faithful wastewater lagoons, Yellowstone National Park

52. Dye-response curves in well OF2 and Iron Spring Creek near the Old Faithful wastewater lagoons, October 1, 1975 through April 25, 1976.

53. Map showing location of the edgedrain-test site on Interstate Highway 25.

54. Generalized transverse section of northbound lanes of Interstate Highway 25 showing retrofitted edgedrain and dye-injection hole

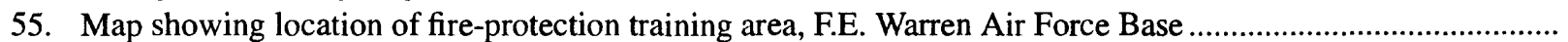

56. Cross-sectional sketch of retention pond in fire-protection training area.

57. Dye-response curve for water pumped from leakage-monitoring station at retention pond in fireprotection training area, September 19, 1990 .

\section{TABLES}

1. Time-of-travel measurements, Green River and tributaries, southwestern Wyoming, 1975-77 .........................

2. Time-of-travel measurements, Little Snake River, southwestern Wyoming, 1976-77...................................... 1

3. Gas desorption-rate coefficients and reaeration coefficients, North Platte River below Casper, Wyoming, October 1985 


\section{TABLES--Continued}

4. Dye-dilution discharge measurements under ice cover, Laramie River at Laramie,

Wyoming, February 1967

5. Dye-dilution discharge measurements at streamflow-gaging stations 06622700 , North Brush Creek near Saratoga, Wyoming, and 06622900, South Brush Creek near Saratoga, Wyoming, 1967-68.

6. Dye-dilution discharge measurements at streamflow-gaging station 06321000 , South Piney Creek near Story, Wyoming, 1971-78

7. Dye-dilution discharge measurements at streamflow-gaging stations and miscellaneous-measurement sites used in the Madison Limestone recharge study, northeastern Wyoming, 1975-78

8. Miscellaneous dye-dilution discharge measurements at streamflow-gaging stations and miscellaneousmeasurement sites in Wyoming, 1971-82.

9. Water temperatures in the Middle Popo Agie River at the Sinks and the Rise and in a spring near the Rise, Sinks Canyon State Park, Wyoming, August 14, 1983

\section{CONVERSION FACTORS}

\begin{tabular}{rll}
\hline Multiply & By & To obtain \\
\hline cubic foot & & \\
cubic foot per minute $\left(\mathrm{ft}^{3} / \mathrm{min}\right)$ & 0.02832 & cubic meter \\
cubic foot per second $\left(\mathrm{ft}^{3} / \mathrm{s}\right)$ & 0.02832 & cubic meter per minute \\
foot (ft) & 0.02832 & cubic meter per second \\
foot per day & 0.3048 & meter \\
foot per second & 0.3048 & meter per day \\
gallon & 0.3048 & meter per second \\
gallon & 3.785 & liter \\
inch & 3,785 & milliliter (mL) \\
mile & 2.54 & centimeter \\
mile per hour & 1.609 & kilometer \\
pound & 1.609 & kilometer per hour \\
& 0.4536 & kilogram \\
\hline
\end{tabular}

Temperature can be converted to degrees Fahrenheit $\left({ }^{\circ} \mathrm{F}\right)$ or degrees Celsius $\left({ }^{\circ} \mathrm{C}\right)$ as follows:

$$
\begin{aligned}
& { }^{\circ} \mathrm{F}=9 / 5\left({ }^{\circ} \mathrm{C}\right)+32 \\
& { }^{\circ} \mathrm{C}=5 / 9\left({ }^{\circ} \mathrm{F}-32\right)
\end{aligned}
$$

Water year: A water year is the 12-month period, October 1 through September 30. It is designated by the calendar year in which it ends. 


\title{
Use of Dye Tracing in Water-Resources Investigations in Wyoming, 1967-94
}

\author{
By James F. Wilson, Jr. and James G. Rankl
}

\section{Abstract}

The U.S. Geological Survey has used dye tracing during many water-resources investigations in Wyoming. When mixed with flowing water, fluorescent dye can be traced to determine velocity (time of travel), dilution capacity, dispersion, and other information. This report describes results of all such investigations between 1967 and 1994, some of which previously were unpublished.

Time of travel and dispersion were measured in eight streams. A 113-mile reach of the Wind/Bighorn River below Boysen Dam was measured during 1971. Measurements were made during 1975 and 1977 in a 117-mile reach of the Green River upstream from Fontenelle Reservoir, in a 70-mile reach downstream, and in parts of four tributaries: East Fork River, Big Sandy River, Horse Creek, and Blacks Fork. A 75-mile reach of the Little Snake River along the Wyoming-Colorado State line was measured during 197677. The North Platte River downstream from Casper was measured during 1978 (36 miles) and twice during 1985 (95 and 94 miles).

Reaeration data were collected concurrently with the October 1985 time-of-travel measurements in the North Platte River. Propane gas and dye were traced through a 40-mile reach, starting at Casper. Reaeration coefficients, used as a measure of the capacity of the river to assimilate organic waste, were calculated for three subreaches.

Seventy dye-dilution measurements of stream discharge were made at 23 different sites. Five measurements, four using various antifreeze additives in the injection solution, were made in February 1967 under total ice cover in the Laramie River at Laramie as part of research to develop field procedures; four of the five were within 2 percent of a current-meter measurement made the same day. The accuracy of discharge-rating curves for streamflow-gaging stations on North and South Brush Creeks near Saratoga were verified with a series of 17 measurements during 1967-68. Similar results were obtained with eight measurements at the station on South Piney Creek near Story during 1971-78. A total of 25 discharge measurements were made during 1975-78 at 11 additional stations at remote sites on steep, rough mountain streams crossing outcrops of the Madison Limestone of Mississippian age in northeastern
Wyoming. The largest discharge measured by dye tracing was 2,300 cubic feet per second at a station on the Tongue River. Most of the dye measurements were considered to be sufficiently accurate for use in defining the stage-discharge relation. Fifteen additional discharge measurements were made at eight other sites during 1971-82.

Four losing streams and one sinking stream in karst terrane were studied using dye tracing. In November 1970, dye injected into a sinkhole in the channel of the North Fork Powder River below Dullknife Reservoir was detected 16 hours later in a spring 5.8 miles downstream from the reservoir. In September 1974, dye injected into North Fork Crazy Woman Creek above zones of flow loss appeared as three separate peaks below springs about 1.3 miles downstream; 73 percent of the amount injected was accounted for by sampling. In October 1974, 35 percent of the dye injected into the Little Tongue River upstream from a losing reach was accounted for 2.6 miles to the north, in a stream in Tongue River Cave. This water eventually reaches the Tongue River, so at least part of the water lost in the Little Tongue does not represent recharge to the limestone aquifer. A dye test at Sinks Canyon State Park during August 1983 verified the connection of the Sinks (Sinks of Lander Cave) to the Rise, on the Middle Popo Agie River. The entire flow disappears into the cave, and surface flow resumes in large springs 3,500 feet downstream. The dye arrived 2 hours after injection, and 84 percent of the injected dye was accounted for by sampling. Dye was used in September 1991 to evaluate water loss in sinks between two stations on Smith Creek near Casper. A weak dye trace appeared at the downstream station about 20 hours after injection at the upstream station, indicating a hydraulic connection between the sinks and flow at the downstream station.

The versatility of dye tracing was demonstrated in four other investigations. Dye was used to tag water in Pass Creek near Wyoming Highway 130 for current-meter measurements at a series of downstream sites; to track flow through glacial deposits of Quaternary age in Yellowstone National Park; as a passive test for leakage of runoff through pavement cracks in Interstate Highway 25 near Wheatland; and as an active test for leaks in a retention pond at F.E. Warren Air Force Base adjacent to Cheyenne. 


\section{INTRODUCTION}

Hydrologists and technicians of the U.S. Geological Survey (USGS) have been using modern dye-tracing techniques in water-resources investigations in Wyoming since 1967. Modern dye-tracing techniques were first reported by Pritchard and Carpenter (1960) and were adapted for hydrologic investigations by the USGS during the early 1960s. Now there are numerous ways to use dye tracing because of its most important characteristicsimplicity of application and detection of the dye.

Dye injected into a stream, lake, well, or artificial impoundment mixes readily and moves with the flowing water. The amount of dye required, compared to the volume of water being tagged, is extremely small, because the dye used, rhodamine WT, is strongly fluorescent in weak concentrations. Special preparation of the sample is not necessary. In an instrument called a fluorometer, the fluorescence of rhodamine WT dye is isolated easily from that of other materials likely to be present in natural waters. The amount of fluorescence varies directly with concentration of dye. The photoelectric output of the fluorometer is directly proportional to fluorescence, and therefore, to concentration of dye (Wilson and others, 1986).

Dye tracing can be used to help answer a broad range of hydrologic questions. As in the earliest known experiments with tracer dyes, the simplest uses have been for water tagging and path tracing: Is this the same water? Where does this water go? What is the source of this water? But dye tracing can reveal much more information about flowing water. Dye tracing can be used to answer these questions: How long does water take to travel between site $A$ and site $B$ ? (or the corollary, How fast does the water travel?), and How does material dissolved in the water become diluted (dispersed) as it travels with the water? And in a variation of the dilution question, accurately measured stream dilution of an injected tracer can be used to calculate the stream discharge when conditions are unfavorable for current-meter measurements. All of these applications of dye tracing have been used in Wyoming.
This report serves two purposes. First, it summarizes all dye tracing by the USGS in Wyoming from 1967 through 1994. Results of some of the investigations have been published previously. Those results are described briefly, and the reader is referred to the published reports for details. Second, this report documents all known uses of dye tracing by the USGS in Wyoming for which results have not previously been published. Those investigations are described in greater detail. A chronology of all dye-tracing applications in Wyoming is provided on the next page.

The report is organized by major tracing topic: time of travel and dispersion of solutes in streams, reaeration coefficients in streams, discharge measurements in streams, investigations in karst (limestone) terrane, and other investigations. The format consists of the combination of text, maps, tables, and graphs for each investigation into one or more articles (thematic units). Each unit is complete on facing pages.

The first unit under each major topic is a brief summary of field and analytical methods for that topic. Detailed descriptions of the techniques are available in published manuals of the USGS: Kilpatrick (1993); Kilpatrick and Cobb (1985); Kilpatrick and Wilson (1989); Kilpatrick and others (1989); Wilson and others (1986).

The USGS conducted most of the investigations described in this report in cooperation with other agencies, particularly the Wyoming State Engineer. Cooperation for each investigation, if applicable, is acknowledged in the text. Also, the field work for many of the investigations was accomplished through the dedicated effort of many hydrologists and technicians, some of whom are unnamed, but whose assistance is appreciated, nevertheless.

We especially recognize the contributions of Hugh W. Lowham. He used dye tracing extensively in his investigations during the 1970s (Bauer and others, 1979; Lowham, 1982; Lowham and Wilson, 1971; Lowry and others, 1976; the dye tests of North Fork Powder River and North Fork Crazy Woman Creek; and many dye-dilution discharge measurements). 


\section{CHRONOLOGY OF DYE TRACING IN WATER-RESOURCES INVESTIGATIONS IN WYOMING}

\begin{tabular}{|c|c|}
\hline Apr. 1966 & $\begin{array}{l}\text { Introduction of dye tracing to Wyoming personnel at Rocky Mountain Area [USGS] Conference on } \\
\text { Fluorometric Techniques at Estes Park, Colo. }\end{array}$ \\
\hline Feb. 1967 & Dye-dilution discharge measurements under ice, Laramie River at Laramie (p. 20-21). ${ }^{\top}$ \\
\hline $\begin{array}{l}\text { Sept. } 1967- \\
\text { Oct. } 1968\end{array}$ & $\begin{array}{l}\text { Dye-dilution discharge measurements of North and South Brush Creeks near Saratoga to verify stage- } \\
\text { discharge ratings for these rough mountain streams (p. 22-27). }\end{array}$ \\
\hline Nov. 1967 & Dye test to aid measurement of ground-water gains in Pass Creek near Wyoming Highway 130 (p. 53$).^{1}$ \\
\hline Mar. 1969 & $\begin{array}{l}\text { Time-of-travel measurement in a 90-mile reach of the Laramie River under ice, by the University of } \\
\text { Wyoming; USGS personnel assisted (Zimmerman, 1970). }\end{array}$ \\
\hline Nov. 1970 & Dye test of water loss in the channel of the North Fork Powder River below Dullknife Reservoir (p. 38-39)! \\
\hline $\begin{array}{r}\text { Mar. 1971; } \\
\text { June } 1971\end{array}$ & $\begin{array}{l}\text { Time-of-travel measurements in a 113-mile reach of the Wind/Bighorn River between Boysen Dam and } \\
\text { Greybull (Lowham and Wilson, 1971; Lowry and others, 1976). }\end{array}$ \\
\hline $\begin{array}{l}\text { June } 1971- \\
\text { June } 1978\end{array}$ & $\begin{array}{l}\text { Dye-dilution discharge measurements of South Piney Creek near Story }(1971-74 ; 1975-78) \text { and } \\
\text { East Fork Big Goose Creek below Park Reservoir (August 1971) (p. 28-29; 34-35). }{ }^{1}\end{array}$ \\
\hline Sept. 1974 & Dye test of water loss in the channel of North Fork Crazy Woman Creek (Boner and others, 1976). \\
\hline Oet. 1974 & $\begin{array}{l}\text { Dye test of subterranean diversion of water from the channel of the Little Tongue River to Tongue } \\
\text { River Cave (Boner and others, 1976). }\end{array}$ \\
\hline $\begin{array}{l}\text { May } 1975- \\
\text { July } 1978\end{array}$ & $\begin{array}{l}\text { Dye-dilution discharge measurements of selected mountain streams in northeastern Wyoming, mainly for a } \\
\text { study of recharge to the Madison Limestone of Mississippian age (p. 30-33) }{ }^{1}\end{array}$ \\
\hline $\begin{array}{l}\text { June } 1975- \\
\text { Aug. } 1977\end{array}$ & $\begin{array}{l}\text { Time-of-travel measurements in about } 187 \text { river miles of the Green River and in various reaches of the East } \\
\text { Fork River, Big Sandy River, Horse Creek, and Blacks Fork (Lowham, 1982). }\end{array}$ \\
\hline $\begin{array}{l}\text { Oct. } 1975- \\
\text { Apr. } 1976\end{array}$ & $\begin{array}{l}\text { Dye test of percolating effluent from a wastewater lagoon through deposits of sand and gravel near Old } \\
\text { Faithful in Yellowstone National Park (Cox, 1986). }\end{array}$ \\
\hline $\begin{array}{l}\text { June } 1976- \\
\text { May } 1977\end{array}$ & $\begin{array}{l}\text { Time-of-travel measurements in a 75-mile reach of the Little Snake River, as part of studies of the Green and } \\
\text { Yampa Rivers (Bauer and others, 1979; Lowham, 1982). }\end{array}$ \\
\hline Nov. 1978 & $\begin{array}{l}\text { Time-of-travel measurement in a 36-mile reach of the North Platte River, Casper to the Dave Johnston Power } \\
\text { Plant (Armentrout and Larson, 1984). }\end{array}$ \\
\hline June 1982 & Dye-dilution discharge measurements of Middle Creek in Yellowstone National Park (p. 34-35). ${ }^{1}$ \\
\hline Aug. 1983 & $\begin{array}{l}\text { Dye test of connection of the Sinks to the Rise, Middle Popo Agie River, Sinks Canyon State Park } \\
\text { (p. 44-49). }{ }^{1}\end{array}$ \\
\hline $\begin{array}{l}\text { May } 1985 ; \\
\text { Oct. } 1985\end{array}$ & $\begin{array}{l}\text { Time-of-travel measurements in a 95-mile reach of the North Platte River, Casper to Orin; } \\
\text { October } 1985 \text { reaeration coefficient measurement near Casper (Rankl and Carnevale, 1989). }\end{array}$ \\
\hline Aug. 1989 & Dye test of edgedrain on Interstate Highway 25 near Wheatland (Jeffcoat and others, 1992). \\
\hline Sept. 1990 & Dye test of the fire-protection training area, F.E. Warren Air Force Base, Cheyenne (p. 58-59). ${ }^{1}$ \\
\hline Sept. 1991 & Dye test of water loss in the channel of Smith Creek below Otter Creek, near Casper (p. 50-51). ${ }^{1}$ \\
\hline $1992-94$ & No dye tracing by U.S. Geological Survey in Wyoming. \\
\hline
\end{tabular}




\section{TIME OF TRAVEL AND DISPERSION OF SOLUTES IN STREAMS}

\section{Methods}

Dye tracing is well suited for obtaining information about water movement and solute transport in stream reaches that typically are many miles long. Time-of-travel, velocity, and dilution information is readily determined from the data. In most streams, a solute becomes evenly distributed (mixed) vertically and laterally within a short distance of the injection site. Longitudinal (downstream) dispersion, which is continuous, is the focus of most time-of-travel measurements (Kilpatrick and Wilson, 1989, p. 1-3).

The USGS has measured time of travel and dispersion in the Wind/Bighorn River, the Green River and several tributaries, the Little Snake River (a tributary of the Yampa River in Colorado), and part of the North Platte River. Each of those investigations is summarized subsequently. The USGS, however, was not the first to measure time of travel in Wyoming.

Gerald R. Zimmerman, a University of Wyoming graduate student, measured time of travel and dispersion in the Laramie River and in a short reach of a small, mountain stream during March, May, and November 1969 . Ice completely covered the river throughout most of the 90-mile study reach in March. That is the longest such dye test of an ice-covered stream in the United States. For details, see Zimmerman (1970).

Data Collection.-Typically, a measured amount of dye is poured into the stream as a line or at several points across the stream-a "slug" injection. Dye also can be injected continuously by pumping. A single-slug or continuous injection can be used to simulate a point source of wastewater (see Kilpatrick, 1993). Diluted by the stream, the dye soon becomes invisible.

Water samples are collected at pre-selected sites downstream as the dye cloud passes. Bridges are especially useful for sampling and are readily identified on topographic maps for determination of distance traveled by the dye. Sampling at a site begins prior to arrival of the dye to measure any natural (background) fluorometric response to the water, as well as to assure sampling of the leading edge of the dye. Sampling at one or more points across the stream is continued at various time intervals - throughout the entire passage of the dye cloud, if possible. Because dye may be at two sampling sites at once and sampling must be done around the clock, the completeness of coverage depends on the number of people available, distances between sites, and ease of access to the sites. Spatial sampling - sampling an entire dye cloud at many points at once-generally is not practical in streams.

The samples are tested in a fluorometer in the field to determine approximate dye concentrations as a guide to sampling, and re-tested later in the laboratory or office after the sample temperatures have stabilized and any suspended material in the water samples has settled. Data-collection procedures are described in greater detail by Kilpatrick and Wilson (1989).

Data Analysis. - The basic result of sampling at a given site is a plot of dye concentration versus elapsed time, called a response curve (fig. 1). Time of travel of leading edge, peak concentration, and average are measured using the response curve for each site. The rate of decrease of the peak concentration and the increasing passage times (both measures of longitudinal dispersion) are determined from the curves for several sites where a single injection of dye was sampled (fig. 2). Spatial information can be extracted from the temporal data in a graph of time of travel versus distance (fig. 3). For example, 40 hours after injection, the March 1971 dye cloud in the Wind/Bighorn River was approximately 23 miles long between Worland and Manderson (fig. 3).

The amount of dye accounted for by sampling at each sampling site is calculated using the stream discharge and the areas under the dye-response curves (see investigations in karst terrane, p. 36). As described by Kilpatrick (1993), such dye-recovery calculations are especially important for simulating waste transport from a point source near the stream.

Nearly all time-of-travel investigations include dye tests at two or three different stream discharges, so that graphs of time of travel versus discharge can be prepared. As illustrated in the next unit, the graphs can be used to estimate time of travel between any two sites at any discharge within the range tested with dye.

Time-of-travel and dispersion characteristics without the benefit of dye tracing can be estimated using the equations of Boning (1974) or the more elaborate procedures of Jobson (1996). 


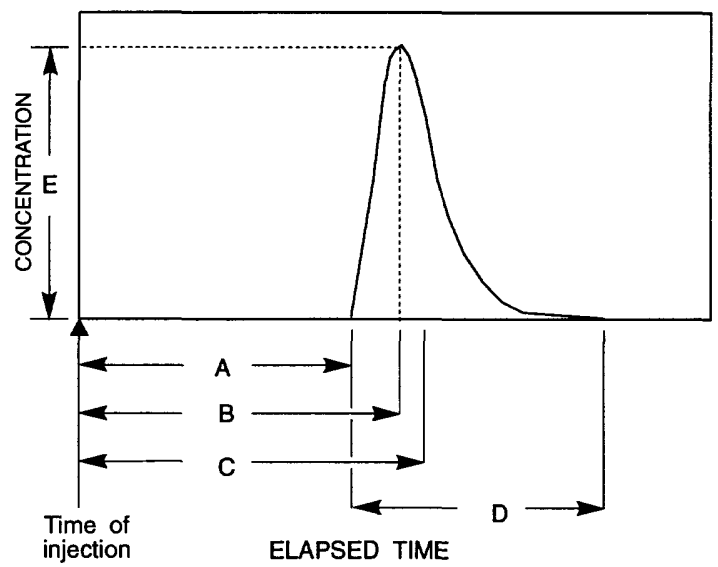

EXPLANATION

A TIME OF TRAVEL OF LEADING EDGE

B TIME OF TRAVEL OF PEAK CONCENTRATION

C AVERAGE TIME OF TRAVEL

D PASSAGE TIME

E PEAK CONCENTRATION

Figure 1. Typical response curve (concentration-time curve) at a point downstream from slug injection of a solute, such as a tracer dye.

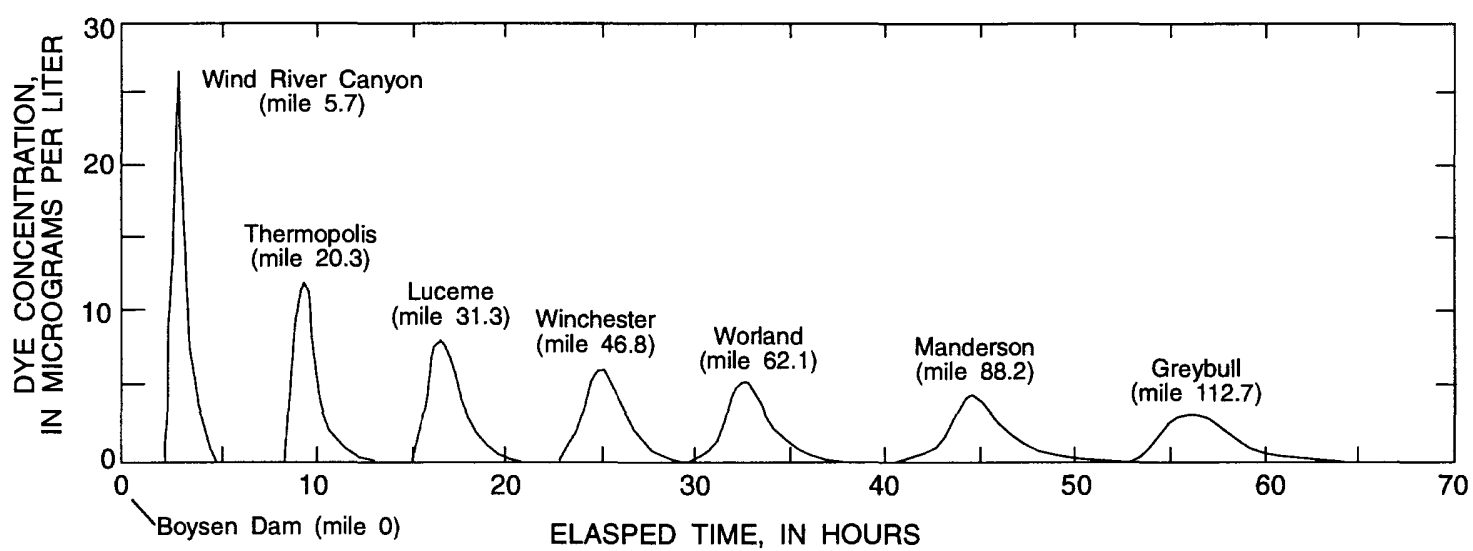

Figure 2. Example of dye-response curves at several sampling sites for a single injection of dye, Wind/Bighorn River, March 1971 (modified from Lowry and others, 1976, sheet 2).

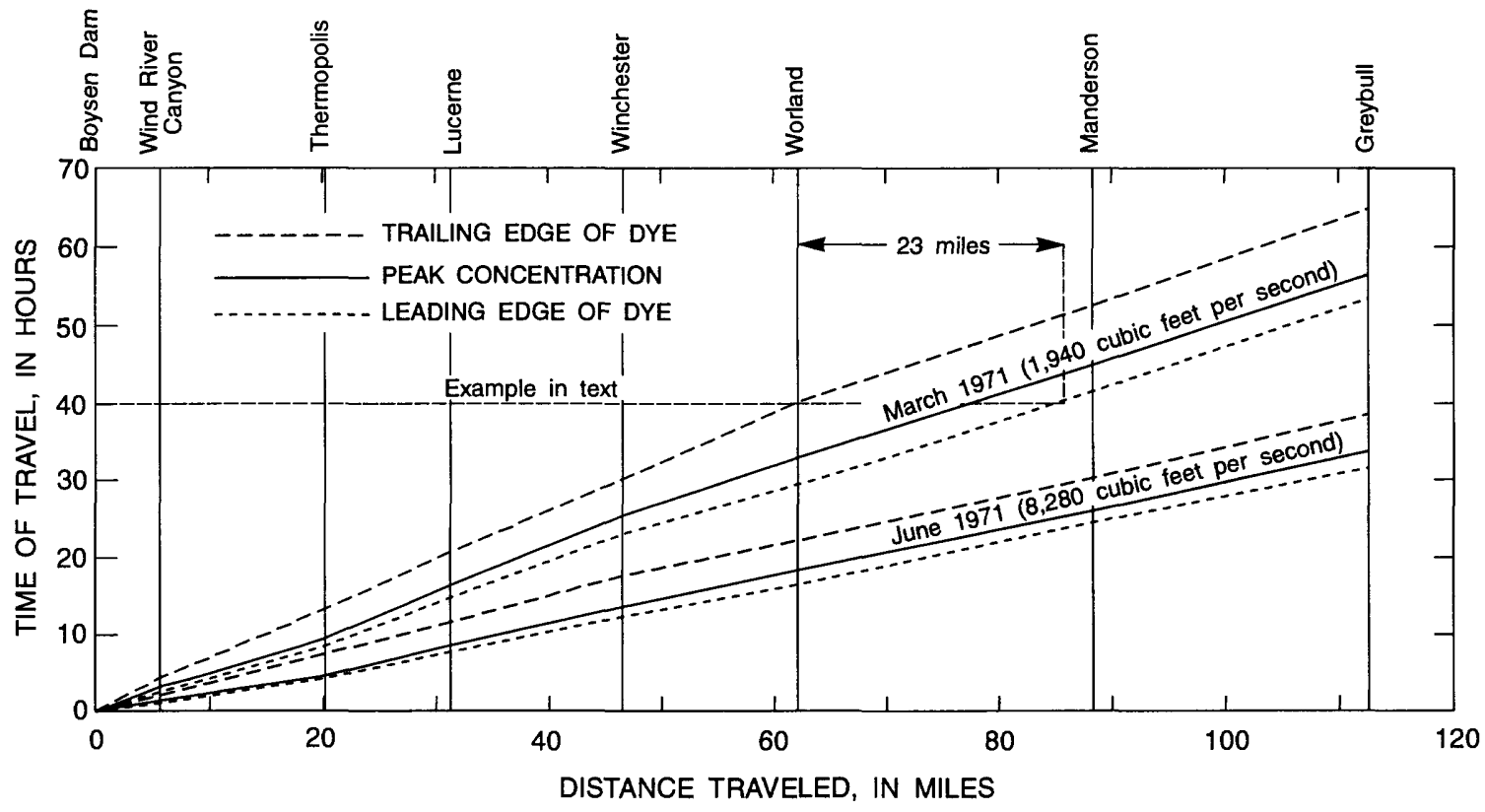

Figure 3. Example of graphical relation of time of travel to distance traveled, Wind/Bighorn River, 1971 (modified from Lowry and others, 1976, sheet 2). Discharges from Boysen Dam are indicated in parentheses. 


\title{
TIME OF TRAVEL AND DISPERSION OF SOLUTES IN STREAMS-Continued
}

\author{
Wind/Bighorn River, 1971
}

\section{[Investigation in cooperation with the Wyoming State Engineer]}

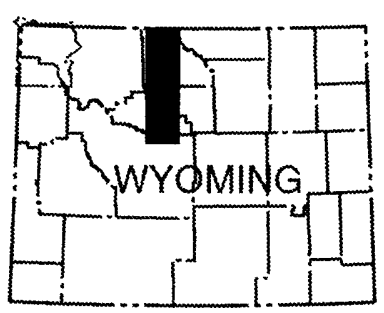

The USGS first measured time of travel and dispersion in Wyoming on the Wind/Bighorn River between Boysen Dam and Greybull (fig. 4; the name changes from Wind River to Bighorn River at the northern end of Wind River Canyon). The study was conducted during 1971 as part of an assessment of the water resources of the Bighorn basin (Lowry and others, 1976). Hugh W. Lowham planned and directed the data collection and analyzed the results. Preliminary results were reported by Lowham and Wilson (1971). A complete analysis by Lowham is in Lowry and others (1976, sheet 2). Lowham's results also were summarized by Wilson (1987).

The first of two measurements was made March 21-24, 1971, when the discharge from Boysen Dam was $1,940 \mathrm{ft}^{3} / \mathrm{s}$ (cubic feet per second). No water was being diverted from the river for irrigation; the discharge increased only $60 \mathrm{ft}^{3} / \mathrm{s}$ between the dam and the mouth of the Greybull River (fig. 4), which provided inflow of about $400 \mathrm{ft}^{3} / \mathrm{s}$. The second measurement was made June 29-30, 1971, when the discharge from the dam was $8,280 \mathrm{ft}^{3} / \mathrm{s}$. A total of about $800 \mathrm{ft}^{3} / \mathrm{s}$ was being diverted into irrigation canals between Thermopolis and Worland, and more than $1,000 \mathrm{ft}^{3} / \mathrm{s}$ of inflow was contributed by the Greybull River.

For both measurements rhodamine WT dye was injected as a single slug, just downstream from Boysen Dam. In March, 42.5 pounds of dye was injected; in June, 40.3 pounds. The passage of the dye was monitored by sampling at seven sites between the dam and Greybull, a distance of 112.7 river miles (fig. 4). Samples at the first site, Wind River Canyon, were collected by throwing a sampler attached to a line into midstream and retrieving it. At all other sites, samples were collected at several points across the river by lowering a sampler from a bridge.

In March, the peak concentration of dye reached the sampling site near Greybull in 56 hours, and the dye cloud took about 12 hours to pass the site (the dyeresponse curves are shown in figure 2, preceding unit). The peak concentration was 3.05 micrograms per liter. In June, the peak reached Greybull in about 33 hours and the dye cloud took about 7 hours to pass. The peak concentration was 0.85 microgram per liter.

The data were exceptionally detailed in both the number of sampling sites and the completeness of sampling, and discharge was nearly steady throughout the study reach. Consequently, Nordin and Sabol (1974) included the data in their compilation of data sets suitable for research of longitudinal dispersion, and Nordin and Troutman (1980) used the data to evaluate dispersion patterns of solutes in flowing water.

Time of travel between any two sites within the study reach can be estimated for a given discharge by interpolation of the graph in figure 5 within the range of discharges measured. Figure 5 is based on the time of travel of the peak concentration, which always is slightly less than the average time of travel of the water (see fig. 1, preceding unit). The relation of the logarithm of time of travel to the logarithm of stream discharge is assumed to be linear (Kilpatrick and Wilson, 1989, p. 21). For some streams, however, a third measurement is needed to verify the linearity of the relation, particularly at very small discharges. Because the range in discharge of the two measurements on the Wind/Bighorn River covered most releases from Boysen Dam, a third measurement was not necessary.

Additional information about the measurements is given in Lowry and others (1976, sheet 2). Graphical data include a river profile, longitudinal variation in discharge and velocity, and traveltime-distance curves for the leading edge, peak concentration, and trailing edge of the dye. These graphs help describe the solute-transport characteristics of the river. 


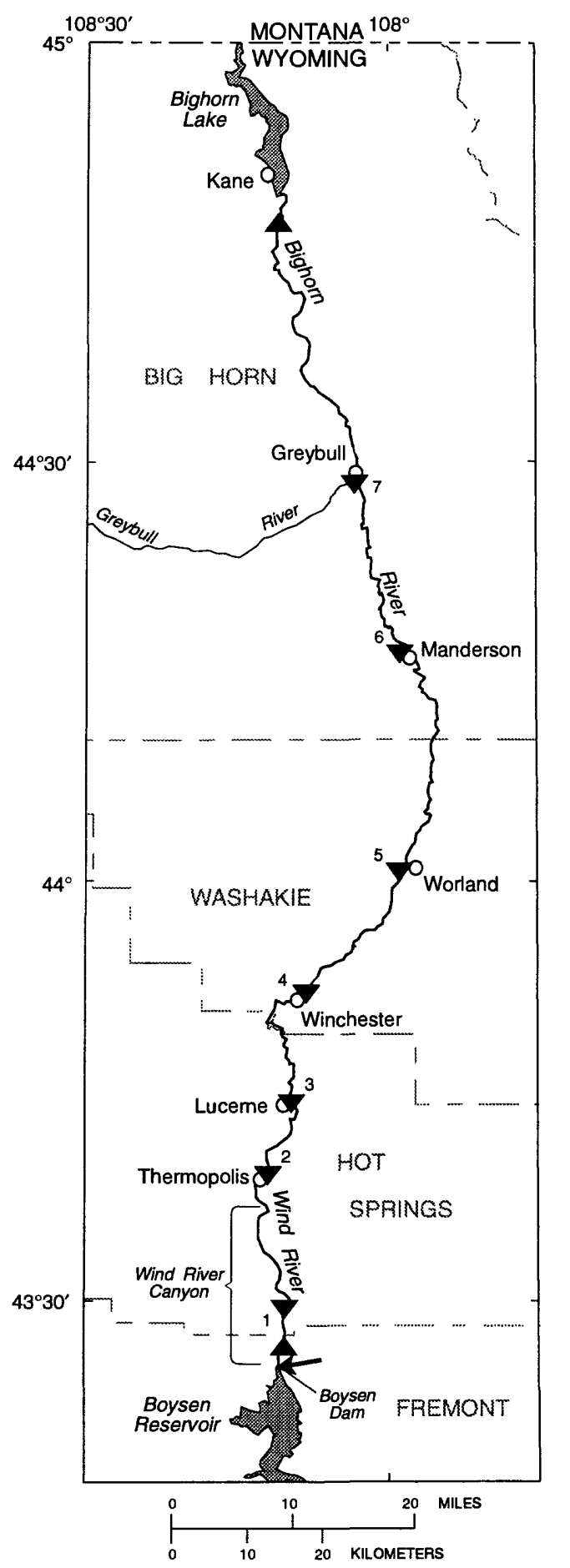

EXPLANATION

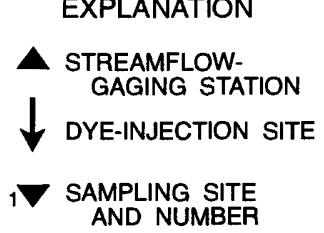

Figure 4. Location of streamflow-gaging stations and dye-injection and sampling sites, Wind/Bighorn River. Site numbers are from Lowry and others (1976, sheet 2).

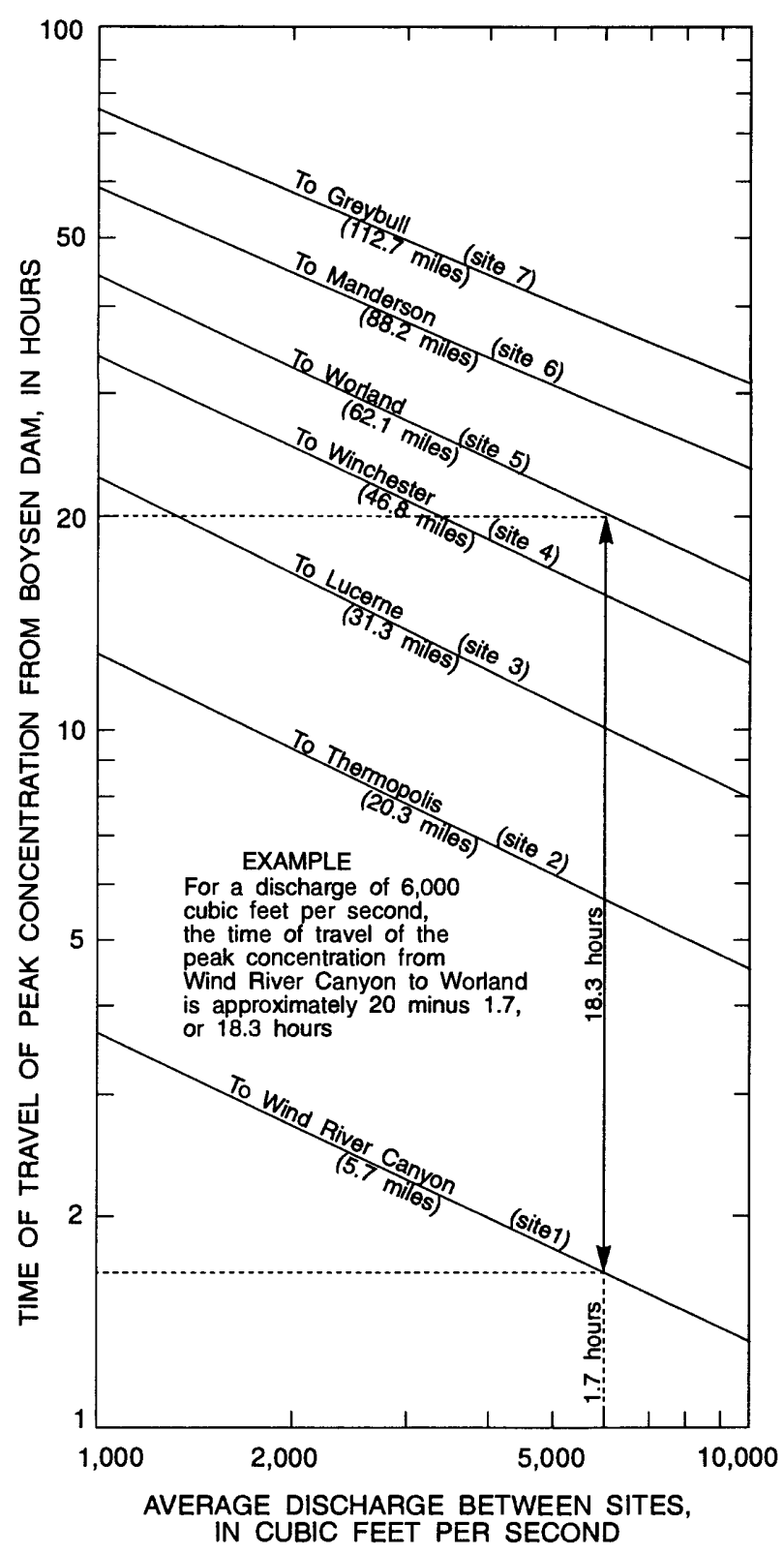

Figure 5. Relation of time of travel to water discharge, Wind/Bighorn River (modified from Lowry and others, 1976, sheet 2). Time of travel between intermediate sites is determined by subtraction, as shown in the example. 


\title{
TIME OF TRAVEL AND DISPERSION OF SOLUTES IN STREAMS-Continued
}

\author{
Green River and Tributaries, 1975-77
}

\author{
[Investigation as part of the U.S. Geological Survey Oil-Shale Hydrology Program]
}

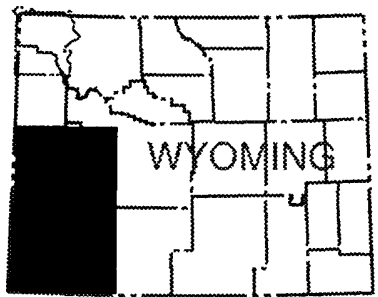

Time of travel and dispersion were measured during 1975-77 as part of an investigation of streamflows and hydraulic and solute-transport characteristics of streams in the Wyoming part of the Green River basin (Lowham, 1982). The information was needed by Federal and State agencies responsible for planning and development of coal, oil-shale, and other mineral resources in southwestern Wyoming.

Equations for estimating channel hydraulic characteristics, such as width, depth, slope, and water velocity, from stream discharge commonly are used in planning and design of water-related projects. Velocities measured at cross sections as a part of streamflow measurements may not be representative of velocities throughout a stream reach; neither, therefore, are equations derived using local velocities. Accurate velocities in a reach, however, can be determined by dividing reach length by time of travel of dye.

The time-of-travel measurements in the Green River and four tributaries that join the Green in Wyoming (fig. 6) are summarized in table 1. Measurements in the Little Snake River, which flows into Colorado, are described in the next unit.

Details of the measurements and results of data analysis are described by Lowham (1982, p. 48-70). Lowham's results indicate that at three streamflowgaging stations, the measured cross sections were not representative of the study reaches. Lowham also notes that for very low flows in some streams, velocities calculated from time-of-travel data may be too small, because the reach lengths measured on topographic maps, which are more representative of medium-to-high flows, are shorter than the distances traveled by the dye. Otherwise, the results indicate reasonably small differences between velocities measured at selected stations and reach velocities measured by dye tracing. An example is shown in figure 7. Graphs for the other reaches listed in table 1 and for the Little Snake River are in the report by Lowham (1982, p. 64-66). That report also includes graphs for predicting time of travel for a specified stream discharge.

Table 1. Time-of-travel measurements, Green River and tributaries, southwestern Wyoming, 1975-77

[Source: Lowham (1982, p. 55-59). Site numbers are shown in figure 6]

\begin{tabular}{|c|c|c|c|}
\hline Date & $\begin{array}{c}\text { Reach } \\
\text { (site } \\
\text { numbers) }\end{array}$ & $\begin{array}{l}\text { Reach length } \\
\text { (miles) }\end{array}$ & $\begin{array}{l}\text { Discharge, start/end } \\
\text { (cubic feet per second) }\end{array}$ \\
\hline \multicolumn{4}{|c|}{ Green River above Fontenelle Reservoir } \\
\hline June 1975 & $1-8$ & 117.3 & $430 / 2,000$ \\
\hline Aug. 1977 & $2-5$ & 47.9 & $264 / 268$ \\
\hline \multicolumn{4}{|c|}{ Green River below Fontenelle Reservoir } \\
\hline June 1975 & $12-15$ & 61.1 & $5,760 / 5,980$ \\
\hline Aug. 1975 & $11-16$ & 70.3 & $1,700 / 1,730$ \\
\hline Aug. 1977 & $12-13$ & 36.1 & $350 / 400$ \\
\hline Aug. 1977 & $13-16$ & 30.6 & $420 / 329$ \\
\hline \multicolumn{4}{|c|}{ East Fork River } \\
\hline June 1975 & $1-6$ & 39.3 & $650 / 916$ \\
\hline July 1975 & $1-5$ & 27.5 & $1,030 / 860$ \\
\hline July 1976 & $2-4$ & 8.9 & $121 / 150$ \\
\hline July 1976 & $3-4$ & 3.0 & $146 / 146$ \\
\hline \multicolumn{4}{|c|}{ Big Sandy River } \\
\hline June 1975 & $3-6$ & 59.1 & $459 / 440$ \\
\hline June 1975 & $7-10$ & 42.6 & $105 / 122$ \\
\hline July 1975 & $7-10$ & 42.6 & $350 / 370$ \\
\hline July 1976 & $1-2$ & 2.3 & $214 / 214$ \\
\hline July 1976 & $2-3$ & 7.5 & $214 / 315$ \\
\hline \multicolumn{4}{|c|}{ Horse Creek } \\
\hline July 1975 & $1-3$ & 13.8 & $250 / 425$ \\
\hline Aug. 1975 & $1-3$ & 13.8 & $10 / 16$ \\
\hline \multicolumn{4}{|c|}{ Blacks Fork } \\
\hline July 1975 & $1-3$ & 7.9 & $1,170 / 1,170$ \\
\hline Aug. 1975 & $1-4$ & 14.4 & $194 / 169$ \\
\hline
\end{tabular}




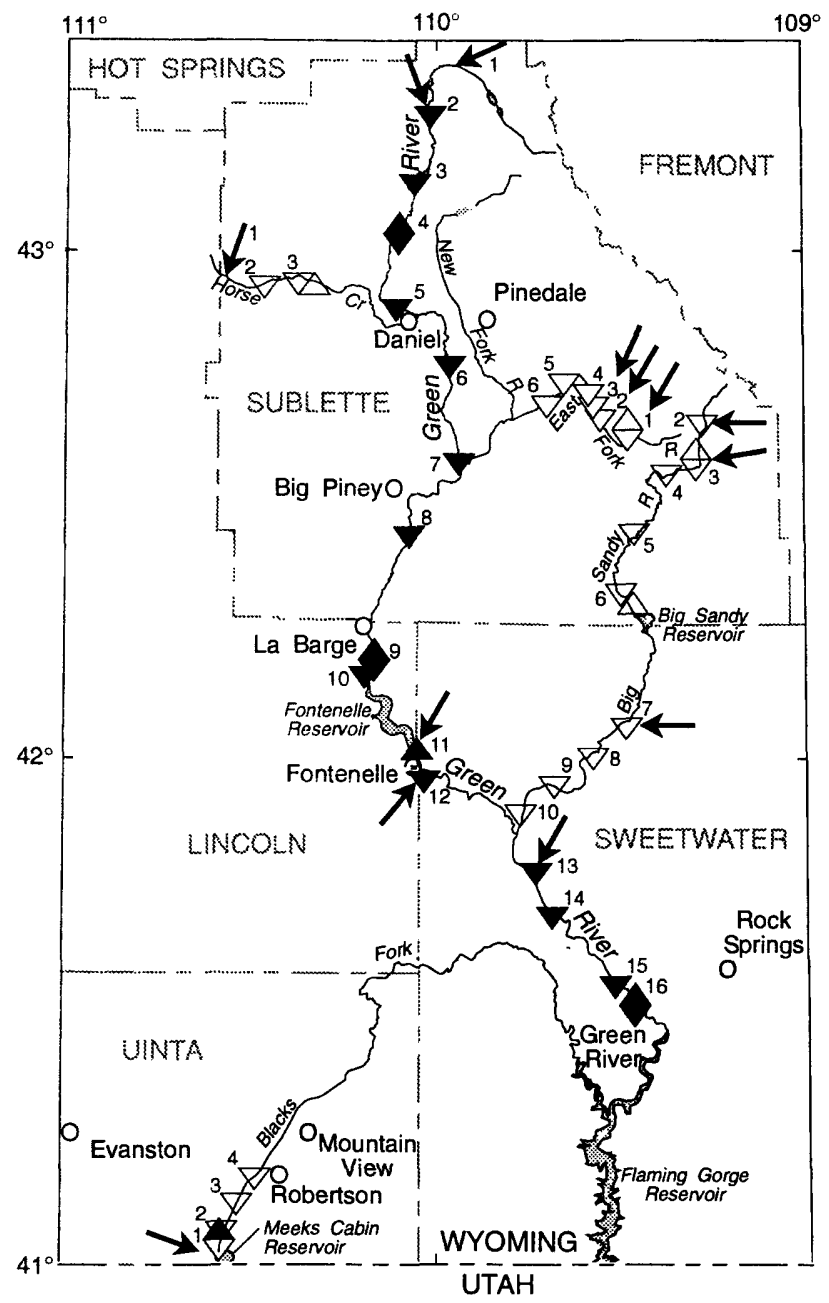

\section{EXPLANATION}

STREAMFLOW-GAGING STATION ON GREEN RIVER STREAMFLOW-GAGING STATION ON TRIBUTARY $13 \downarrow$ DYE-INJECTION SITE AND NUMBER $15 \nabla$ GREEN RIVER SAMPLING SITE AND NUMBER

${ }_{10} \nabla$ TRIBUTARY SAMPLING SITE AND NUMBER

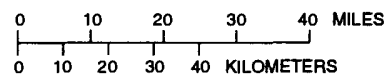

Figure 6. Location of streamflow-gaging stations and dye-injection and sampling sites, Green River, East Fork River, Big Sandy River, Horse Creek, and Blacks Fork. Site numbers are from Lowham (1982). Sites are numbered independently for each stream.

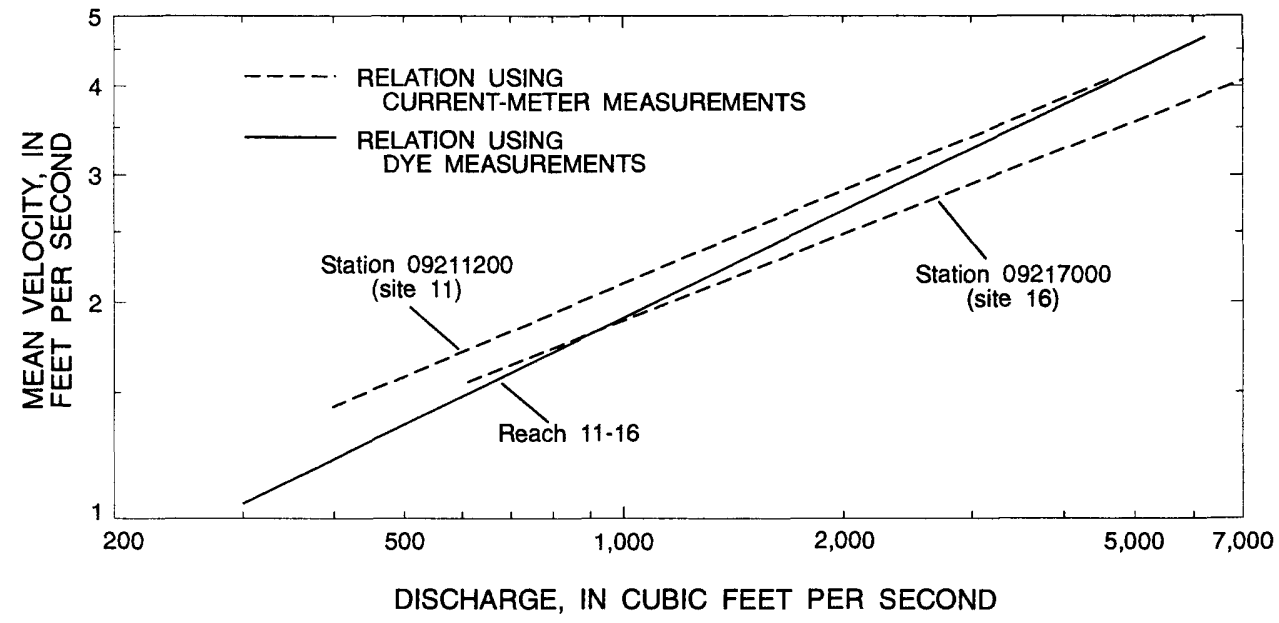

Figure 7. Relation of mean velocity to water discharge at two streamflow-gaging stations and in a 70.3-mile reach, Green River downstream from Fontenelle Reservoir (modified from Lowham, 1982, fig. 29). 


\title{
TIME OF TRAVEL AND DISPERSION OF SOLUTES IN STREAMS-Continued
}

\author{
Little Snake River, 1976-77
}

\author{
[Investigation as part of the U.S. Geological Survey Oil-Shale Hydrology Program \\ and the U.S. Geological Survey Yampa River Basin Assessment]
}

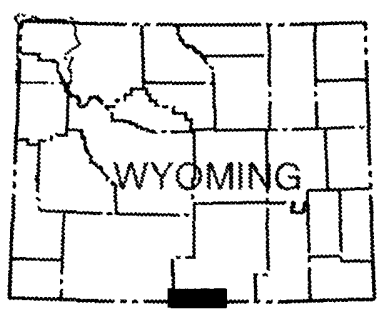

Time-of-travel and dispersion data were collected in the Wyoming part of the Little Snake River (fig. 8) during 1976 and 1977. The measurements were used in a USGS assessment of the water resources of the Yampa River basin in Colorado and Wyoming (Steele and others, 1979). Because of the substantial economic development in the basin, there was an immediate need for information for water planning and management-particularly information about streamflow and waste-transport characteristics of the Yampa and its largest tributary, the Little Snake River. The Little Snake joins the Yampa in Colorado approximately 77 river miles southwest of site 13 (fig. 8).

The Little Snake time-of-travel measurements, directed by Hugh W. Lowham, USGS, Wyoming, were coordinated with similar work on the Yampa, conducted by USGS personnel from Colorado. The overall study reach was subdivided into subreaches for dye injection and sampling (fig. 8). Time-of-travel and longitudinal-dispersion data for three different discharges were collected. The measurements are summarized in table 2 .

Results of the dye measurements in both the Yampa River and the Little Snake River are described in detail by Bauer and others (1979) and by Lowham (1982). Bauer and others (1979, p. 25-30 and p. 33-34) include graphs that can be used for predicting time of travel and unit concentration for a given discharge at either of the two streamflow-gaging stations in the study reach (fig. 8, sites 1 and 8 ). The graph for site 8 is shown in figure 9.

As discussed in the preceding unit on the Green River and tributaries, the report by Lowham emphasizes mean velocities. Lowham (1982, p. 66) compared mean velocities determined from the dye measurements in the study reach of the Little Snake River with mean velocities measured with current meters at the two stations. He reported marked differences between the velocities measured with dye and velocities measured with a current meter. Lowham (1982, p. 54) attributes the differences to the fact that the cross sections where current-meter measurements were made are not representative of cross sections throughout the study reach.

Table 2. Time-of-travel measurements, Little Snake River, southwestern Wyoming, 1976-77

[Source: Bauer and others (1979, p. 13-14). Site numbers are shown in figure 8]

\begin{tabular}{cccc}
\hline Date & $\begin{array}{c}\text { Reach } \\
\text { (site } \\
\text { numbers) }\end{array}$ & $\begin{array}{c}\text { Reach length } \\
\text { (miles) }\end{array}$ & $\begin{array}{c}\text { Discharge, start/end } \\
\text { (cubic feet per second) }\end{array}$ \\
\hline June 1976 & $8-13$ & 42.9 & $1,690 / 1,690$ \\
June 1976 & $1-8$ & 32.4 & $1,400 / 2,070$ \\
Sept. 1976 & $11-12$ & 3.0 & $25.0 / 25.0$ \\
Sept. 1976 & $9-10$ & 3.5 & $32.4 / 32.4$ \\
Sept. 1976 & $7-8$ & .9 & $30.0 / 30.0$ \\
Sept. 1976 & $4-5$ & 4.8 & $30.0 / 30.0$ \\
Sept. 1976 & $1-2$ & 3.4 & $20.0 / 20.0$ \\
May 1977 & $9-13$ & 33.3 & $668 / 668$ \\
May 1977 & $4-8$ & 23.1 & $711 / 666$ \\
May 1977 & $1-6$ & 17.7 & $596 / 711$ \\
\hline
\end{tabular}




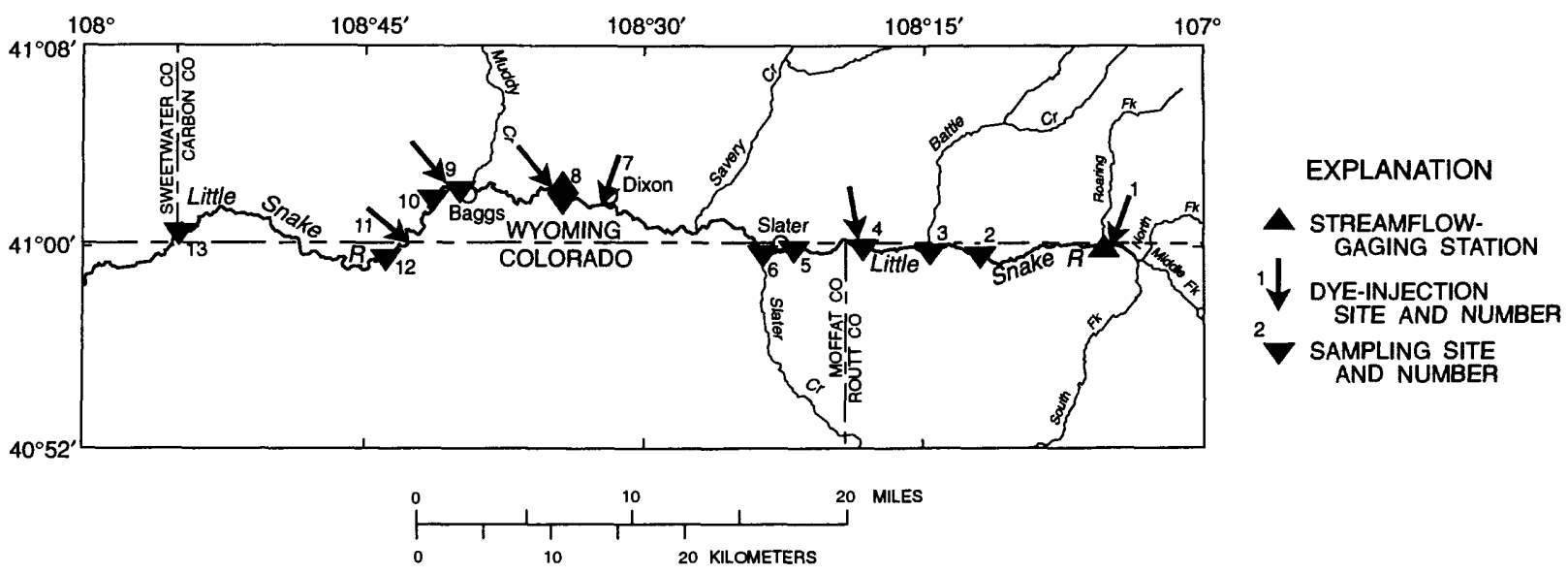

Figure 8. Location of streamflow-gaging stations and dye-injection and sampling sites, Little Snake River. Site numbers are from Bauer and others (1979).

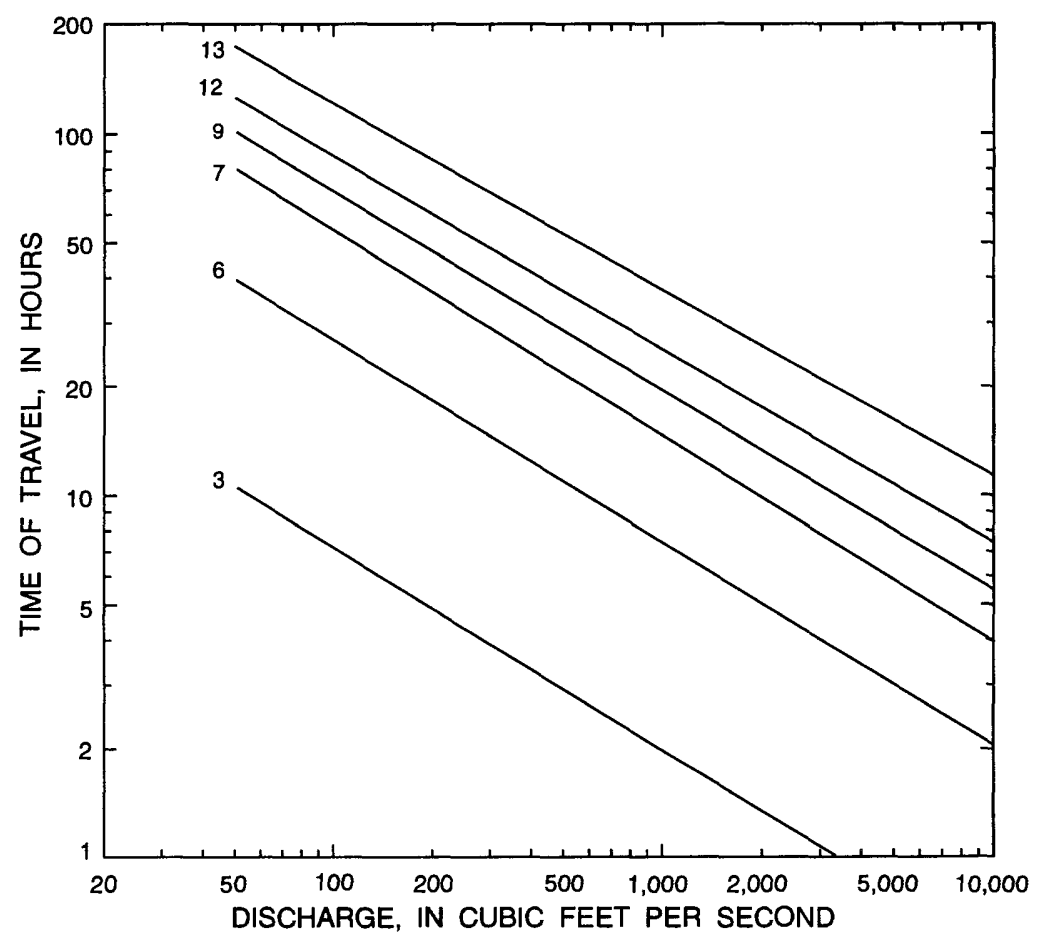

Figure 9. Relation of time of travel to water discharge at streamflowgaging station 09257000, Little Snake River near Dixon, Wyoming (site 8) (modified from Bauer and others, 1979, fig. 12). Numerals are site numbers shown in figure 8 . Time of travel is from the upstream gaging station (site 1) to the indicated site. 


\title{
TIME OF TRAVEL AND DISPERSION OF SOLUTES IN STREAMS-Continued
}

\author{
North Platte River, 1978, 1985
}

[Investigation in cooperation with the Wyoming Department of Environmental Quality]

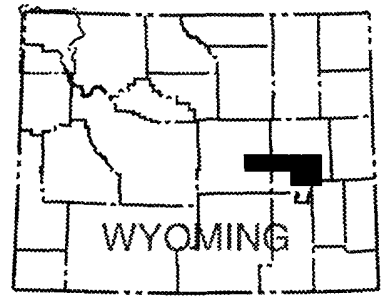

Possibilities for hazardous-waste spills into the North Platte River between Casper and Orin are numerous. Two railroads and Interstate Highway 25 parallel and cross the river. In addition, numerous pipelines cross the river, and several cities discharge treated wastewater into the river.

To provide information that might be useful in the event of a hazardous-waste spill, the USGS measured time of travel and dispersion in the river during 1978 and 1985. The 1985 work included measurement of reaeration coefficients. The Wyoming Department of Environmental Quality provided both personnel and funding, and co-authored and published the results (Rankl and Carnevale, 1989).

From Casper the North Platte River flows eastward along the northern edge of the Laramie Mountains to Orin (fig. 10). The flow is regulated by a series of reservoirs upstream from Casper. The river is freeflowing in the study reach except for a low dam at the Dave Johnston Power Plant near Glenrock. About 3 miles downstream from Orin, the North Platte River flows into Glendo Reservoir.

Four sets of time-of-travel and dispersion data were collected in the North Platte River between Casper and Orin. The first measurement was made on the upper 36 miles of the reach on November 7-8, 1978 at a discharge of $940 \mathrm{ft}^{3} / \mathrm{s}$ (Armentrout and Larson, 1984). The second measurement was made on the entire 95-mile reach on May 14-15, 1985 at a discharge of $3,100 \mathrm{ft}^{3} / \mathrm{s}$. The third measurement was made in conjunction with a reaeration measurement on 40 of the first 41 miles of the study reach on October 9-10, 1985; the discharge was about $800 \mathrm{ft}^{3} / \mathrm{s}$. The fourth measurement was made on the last 54 miles of the study reach on October 10-12, 1985 at a discharge of $890 \mathrm{ft}^{3} / \mathrm{s}$ (Rankl and Carnevale, 1989, p. 8).

For measurements 1, 2, and 4, rhodamine WT dye was slug-injected into the river. On November 7, $1978,19.85$ pounds of dye was injected from the center of the Bryon Stock Trail Bridge in Casper (site 4, fig. 10). For the May 14-15, 1985 measurement, 24.50 pounds of dye was injected into the center of the river from the abandoned U.S. Highway $20-26$ bridge on the western city limits of Casper (site 1, fig. 10). On October 10,1985, 9.89 pounds of dye was injected into the center of the river from the abandoned U.S. Highway 87 bridge downstream from Dave Johnston Power Plant (site 17, fig. 10). That injection site was the farthest-downstream sampling point for measurements 1 and 3 .

Dye and gas tracers were injected concurrently at the First Street bridge in Casper (site 2, fig. 10) on October 9, 1985, to measure both time of travel (measurement 3 ) and reaeration. Two fluid-metering pumps were used to inject 25.29 pounds of 4.76 -percent solution of rhodamine WT dye at a constant rate for 2 hours. At the same time, propane gas was injected into the water through porous-plate diffusers (the reaeration part of the investigation is described on p. 16-17 of this report).

Locations of sampling sites used for one or more of the measurements are shown in figure 10. For the 1985 measurements, equations developed by Boning (1974) for estimating time of travel were used to plan and develop sampling schedules. The equations proved quite accurate for the North Platte River.

Graphical relations developed from the data include the following: velocity in relation to discharge (fig. 11); dye-cloud passage time in relation to distance downstream from the injection (fig. 12); and unit-peak concentration in relation to time of travel (fig. 13). For detailed explanations of these relations and additional time-of-travel relations, see Rankl and Carnevale (1989). 


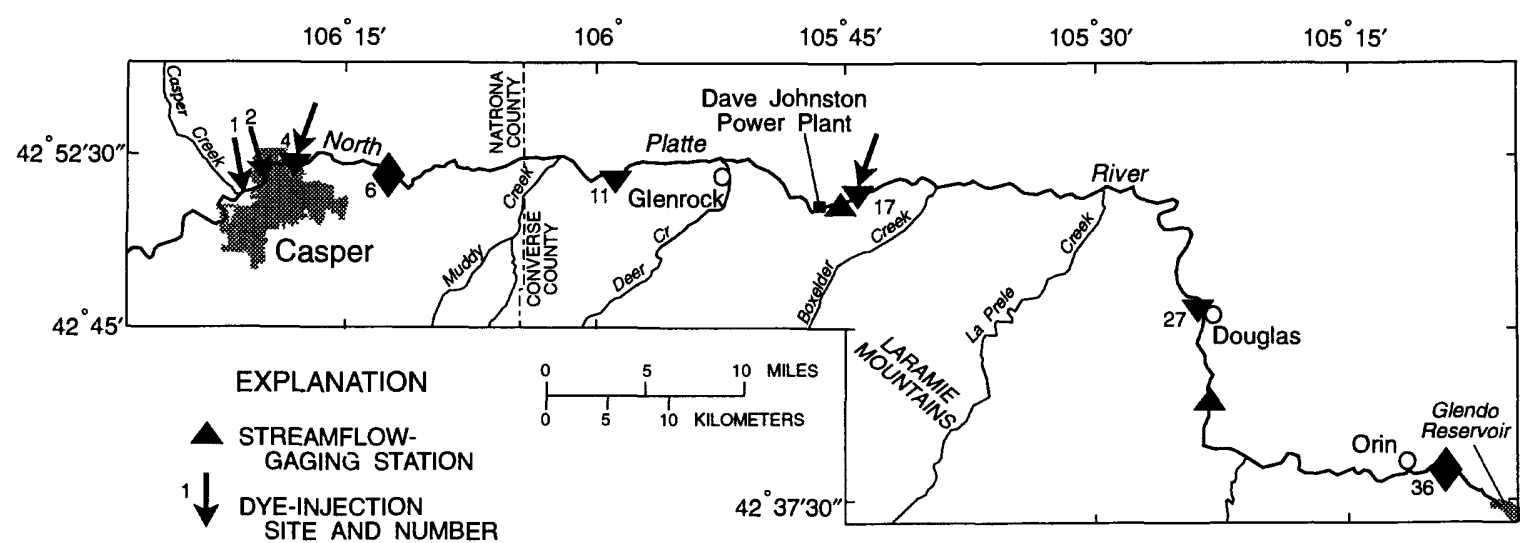

SAMPUING SITE

AND NUMBER

Figure 10. Location of streamflow-gaging stations and dye-injection and sampling sites, North Platte River. Site numbers are from Rankl and Carnevale (1989).

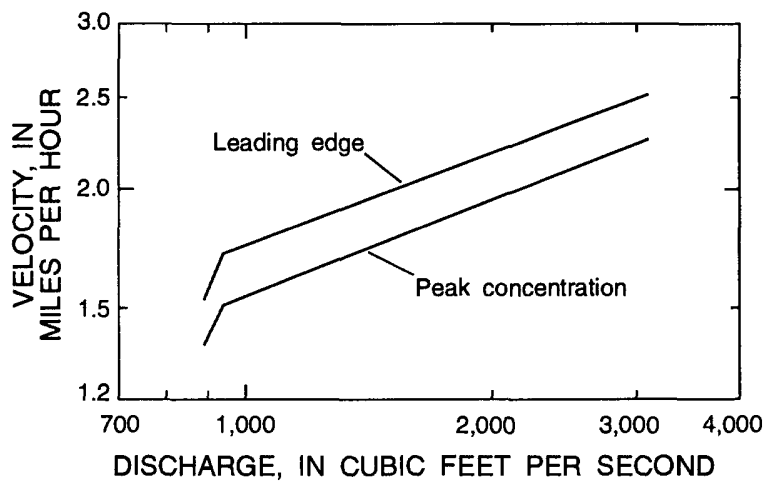

Figure 11. Velocity-discharge relations for leading edge and peak concentration of dye cloud, North Platte River between Casper and Orin, Wyoming. Break in slope of curves indicates change in flow regime (see fig. 13) (modified from Rankl and Carnevale, 1989, fig. 9).

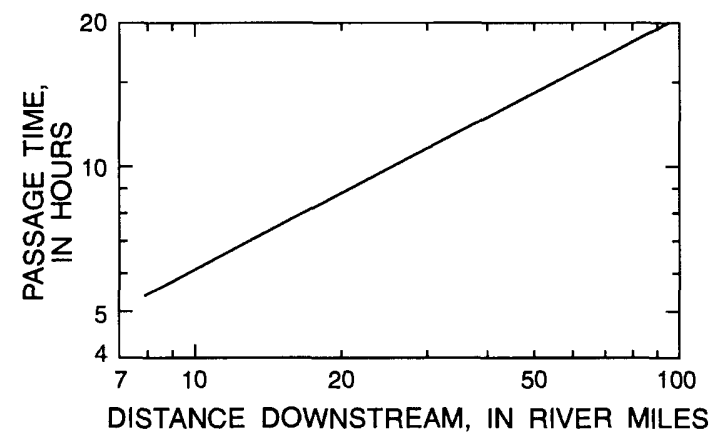

Figure 12. Relation between passage time of dye cloud and distance downstream from the point of injection, North Platte River between Casper and Orin, Wyoming (modified from Rankl and Carnevale 1989, fig. 10).

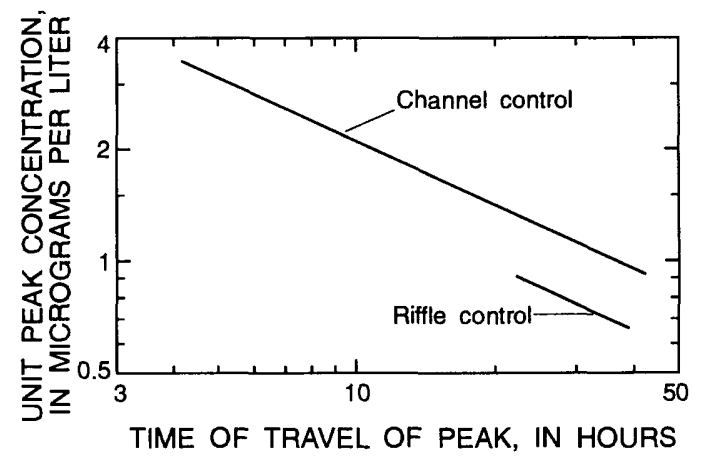

Figure 13. Relation between unit-peak concentration and time of travel of peak, North Platte River between Casper and Orin, Wyoming (modified from Rankl and Carnevale, 1989, fig. 11). Concentrations are for an injection of 1 pound of dye and a stream discharge of 1,000 cubic feet per second. 


\title{
REAERATION COEFFICIENTS IN STREAMS
}

\author{
Methods
}

Biodegradation of organic waste in a stream consumes dissolved oxygen. Reaeration is the physical process by which dissolved oxygen removed from the stream is replaced by oxygen absorbed from the atmosphere. The rate of oxygen absorption is expressed as a reaeration coefficient. Mathematical dissolvedoxygen models are used to quantify the amount of organic waste that can be discharged to the stream without depleting the supply of dissolved oxygen. Use of a dissolved-oxygen model to compute an oxygen balance requires reaeration coefficients for the reach of stream being investigated.

A direct method of measuring reaeration coefficients was developed by Tsivoglou (1967) using Krypton- 85 radioactive gas for a tracer. The method is based upon the concept that tracer gas coming out of the water (desorbed) is related inversely to oxygen going into the water (absorbed). However, injecting a radioactive gas into a stream created safety concerns and permitting problems with the regulatory agencies.

A modified tracer technique, using propane or ethylene as a tracer, was developed and tested by Rathbun and others (1975) and Rathbun and Grant (1978). Procedures for applying the modified tracer technique are described by Kilpatrick and others (1989).

With the modified tracer technique, propane or ethylene gas is injected into the stream at a constant rate by bubbling the gas through porous-plate diffusers. The number of diffusers required depends on the discharge (Kilpatrick and others, 1989, table 2, p. 17). The gas is supplied from 100-pound tanks equipped with pressure regulators and flow meters. At the same time the gas is injected into the stream, rhodamine WT dye is injected using small, battery-operated fluidmetering pumps. The dye serves as an inexpensive, easily monitored guide for collecting samples of the gas, and also provides the quantitative measures of dilution and dispersion needed to calculate reaeration coefficients.

Dye and gas samples are collected at two or more sites. The dye samples are analyzed in the field using a fluorometer. The timing of the gas sampling is controlled by information obtained from the onsite evaluation of the dye-response curve. Samples for the analysis of gas concentrations are collected at a minimum of three points across the stream using a directdisplacement sampler. The sample bottles are filled completely to exclude all air bubbles, injected with a small quantity of formalin solution to prevent biological degradation during storage, and tightly sealed. The samples are shipped as soon as possible to the laboratory for analysis.

Two methods are available for calculating the gas desorption-rate coefficients: the area method and the peak method. With the area method, the change of mass of the gas tracer over a selected reach is calculated. Mass is equal to the area under the gas-response curve multiplied by the stream discharge. The coefficients for the area method are calculated using equation 1 . This method requires a large number of gas samples to define an entire gas-response curve.

With the peak method, the gas desorption-rate coefficients are calculated from the change in gas concentration over a selected reach. Gas concentration is measured at a characteristic time on the upstream and downstream gas-response curves. The characteristic time most used is that of the peak concentration of the corresponding dye-response curve. The coefficients for the peak methods are calculated using equation 2 . The gas desorption-rate coefficients for both the area method and the peak method are adjusted by a ratio, $\boldsymbol{J}$, of the calculated dye recovery at the upstream site to that at the downstream site.

Equation 3, developed by Rathbun and others (1978), is used to convert gas desorption-rate coefficients to oxygen-absorption coefficients (reaeration coefficients). Equation 4 (Kilpatrick and others, 1989, p. 8 ) is used to adjust the reaeration coefficients to $20^{\circ} \mathrm{C}$ (degrees Celsius).

Reaeration coefficients for unsteady flow in a dye-tested reach may be estimated using the numerical routing model described by Jobson (1987) calibrated with the dye- and gas-tracing data for steady flow. 


\section{Gas Desorption-Rate Coefficients}

\section{Area Method}

With the area method, the gas desorption-rate coefficient, $\boldsymbol{K}_{\mathrm{T}}$, is calculated using the following equation (Kilpatrick and others, 1989, eq. 14, p. 9):

$$
K_{\mathrm{T}}=\frac{1}{\boldsymbol{t}_{\mathrm{c}}} \ln \left[\frac{\left(\boldsymbol{A}_{\mathrm{g}} \boldsymbol{Q}\right)_{\mathrm{u}}}{\left(\boldsymbol{A}_{\mathrm{g}} \boldsymbol{Q}\right)_{\mathrm{d}}}\right],
$$

where $t_{c}$ is the time of travel of the centroid

(average time of travel) of the dye cloud between the selected sections, in hours;

$\boldsymbol{A}_{\mathrm{g}}$ is the area under the gas-response curve at the upstream (u) and downstream (d) sites, in micrograms per liter-hour; and

$\boldsymbol{Q}$ is the stream discharge at the upstream (u) and downstream (d) sites, in cubic feet per second.

The centroids of the dye cloud and the gas cloud are calculated for the upstream and downstream sites by taking moments with respect to time of each response curve. The areas of the gas-response curves, $\boldsymbol{A}_{\mathrm{g}}$, are calculated by numerical integration or by planimetering.

\section{Peak Method}

With the peak method, the gas desorption-rate coefficient, $\boldsymbol{K}_{\mathrm{T}}$, is calculated using the following equation (Kilpatrick and others, 1989, eq. 13, p. 8):

$$
K_{\mathrm{T}}=\frac{1}{t_{\mathrm{p}}} \ln \left[\frac{\left(\frac{C_{\mathrm{g}}}{C_{\mathrm{p}}}\right)_{\mathrm{u}}}{\left(\frac{C_{\mathrm{g}}}{C_{\mathrm{p}}}\right)_{\mathrm{d}}}\right] J
$$

where $\boldsymbol{C}_{\mathrm{g}}$ is the concentration of propane at the peak concentration of the dye cloud, $\boldsymbol{C}_{\mathrm{p}}$, at the upstream (u) and downstream (d) sites, both in micrograms per liter;

$\boldsymbol{t}_{\mathrm{p}}$ is the time of travel of the peak dye concentration between the upstream (u) and downstream (d) sites, in hours; and

$\boldsymbol{J}$ is the ratio of dye recovery at the upstream site to that at the downstream site. Calculation of dye recovery is described in the methods for investigations in karst terrane (p. 36 of this report).

\section{Reaeration Coefficients}

The following equation developed by Rathbun and others (1978) is used to convert the gas desorption-rate coefficient, $\boldsymbol{K}_{\mathrm{T}}$, determined with either the area method or the peak method, to the reaeration coefficient, $K_{2}$ :

$$
K_{2}=1.39 K_{\mathrm{T}} .
$$

Reaeration coefficients are expressed for a stream temperature of $20^{\circ} \mathrm{C}$ as $\boldsymbol{K}_{2_{20}}$. The following equation is used to calculate $\boldsymbol{K}_{2_{20}}$ for stream temperature $T$ in degrees Celsius (Kilpatrick and others, 1989, eq. 8, p. 8):

$$
K_{20}=K_{2}(1.0241)^{(20-T)} .
$$




\title{
REAERATION COEFFICIENTS IN STREAMS-Continued
}

\author{
North Platte River, 1985
}

\section{[Investigation in cooperation with the Wyoming Department of Environmental Quality]}

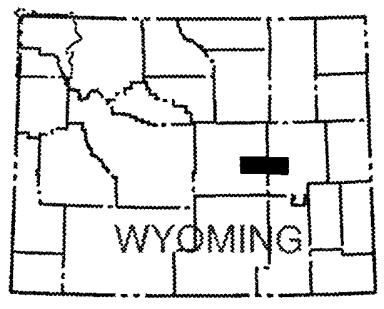

Discharge of treated wastewater from cities and industry into the North Platte River has the potential to affect water quality of the river. In 1985 the USGS and Wyoming Department of Environmental Quality investigated the reaeration capacity of the North Platte River downstream from Casper (Rankl and Carnevale, 1989). The information was needed for applying a mathematical dissolved-oxygen model to the reach extending from the First Street bridge in Casper to the abandoned U.S. Highway 87 bridge downstream from Dave Johnston Power Plant near Glenrock (site 2, fig. 14).

The North Platte River in the study reach is freeflowing, except for a low-head dam at Dave Johnston Power Plant. Inflows to the river are minimal, with the largest coming from Deer Creek. Deer Creek has an October mean flow of $14 \mathrm{ft}^{3} / \mathrm{s}$ (Peterson, 1988, p. 348).

On October 9, 1985 at 11:00 p.m., at a river discharge of $800 \mathrm{ft}^{3} / \mathrm{s}$, rhodamine WT dye and propane gas were injected into the North Platte River at the First Street bridge in Casper (site 2, fig. 14). Two fluidmetering pumps were used to inject 25.29 pounds of 4.76-percent solution of rhodamine WT dye at a constant rate for 2 hours. Simultaneously, propane gas was injected at a rate of $36.0 \mathrm{ft}^{3} / \mathrm{min}$ (cubic feet per minute). The air temperature at the time of the injection of dye and gas was $-6^{\circ} \mathrm{C}$, and the water temperature was $5^{\circ} \mathrm{C}$. The cold air temperature caused a loss of pressure in the propane tanks, resulting in a flow rate of $31.2 \mathrm{ft}^{3} / \mathrm{min}-13$ percent less than the design rate. The flow rate could not be increased by adjusting the flow meters. After the first hour of injection, the propane tanks were placed in the river to increase the tempera- ture of the propane. The flow rate returned to the design rate almost immediately.

Separate sets of water samples for dye and propane concentration were collected at Bryon Stock Trail bridge, 3.0 miles downstream from injection (site 4 , fig. 14); Mystery bridge, 8.5 miles downstream from injection (site 6); Cole Creek Road bridge, 23.6 miles downstream from the injection (site 11); and at abandoned U.S. Highway 87 bridge, 40.1 miles downstream from injection (site 17). Dye samples were tested in a fluorometer in the field. Dye-response curves were prepared in the field and used to guide the sampling for propane gas. Because the dye-response curves (fig. 15) indicated nearly complete lateral mixing at the Bryon Stock Trail bridge, propane samples were collected only at the center of flow.

The gas-response curve (fig. 16) is nearly identical in shape to that of the dye-response curves (fig. 15) except for the secondary plateau resulting from the increased gas flow rate described previously. Because the peak of the gas-response curve was at or near the peak of the dye-response curve, the peak method was considered acceptable for calculation of the gas desorption-rate coefficients for all three subreaches.

The areas under the gas-response curves were determined for the first three sampling sites. However, insufficient data and low concentrations prevented defining the total mass of gas tracer at the fourth site. Therefore, use of the area method to calculate gas desorption-rate coefficients was limited to subreaches 1 and 2 (fig. 14).

Reaeration coefficients are listed in table 3 . The average of the four values for subreaches 1 and 2 5.38 - is considered to be the best estimate of the reaeration coefficient for the reach of the North Platte River between Casper and the small reservoir at Dave Johnston Power Plant. The higher reaeration coefficient for subreach 3 (fig. 14) probably is the result of residence time in the reservoir and flow over the dam at the power plant. Details of this investigation are described by Rankl and Carnevale (1989). 

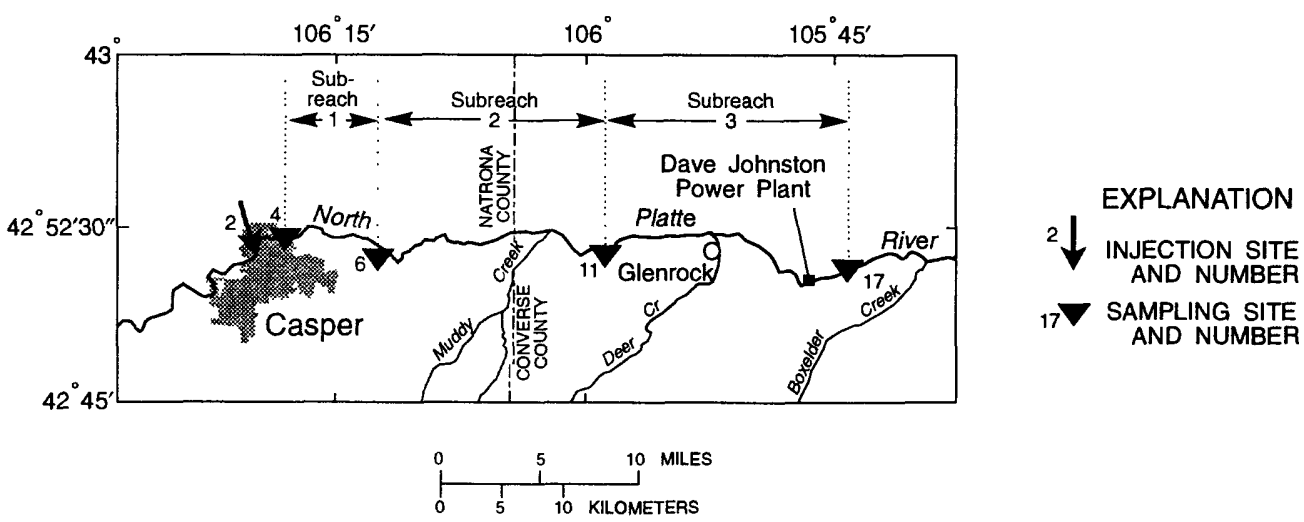

Figure 14. Location of dye- and gas-injection sites and sampling sites, and subreaches for which reaeration coefficients were calculated, North Platte River. Site numbers are from Rankl and Carnevale (1989).

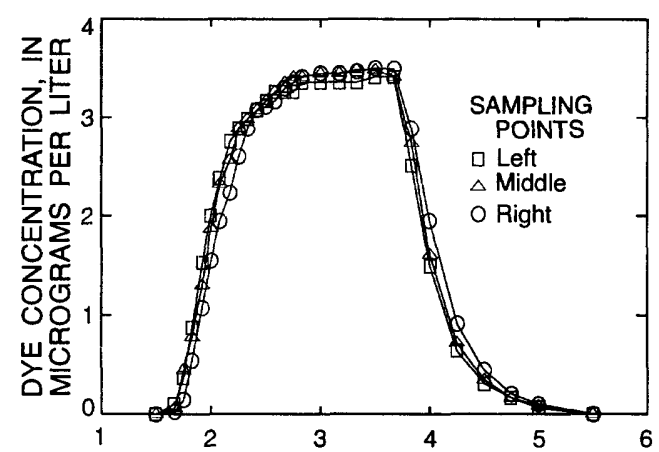

TIME AFTER START OF INJECTION, IN HOURS

Figure 15. Dye-response curves in North Platte River at Bryon Stock Trail bridge (site 4), October 9, 1985. Similarity of curves indicates that lateral dispersion is nearly complete (from Rankl and Carnevale, 1989, fig. 5).

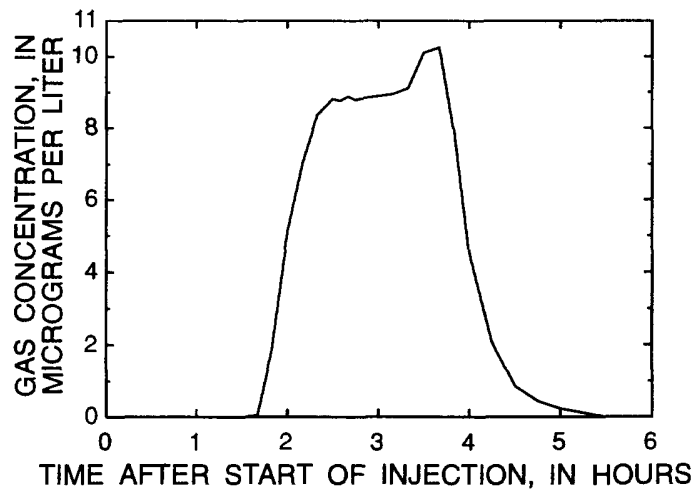

Figure 16. Gas-response curve in North Platte River at Bryon Stock Trail bridge (site 4), October 9, 1985 (previously unpublished).

Table 3. Gas desorption-rate coefficients and reaeration coefficients, North Platte River below Casper, Wyoming, October 1985

[Source: Rankl and Carnevale (1989, p. 26). Subreach locations are shown in figure 14. Coefficients are in logarithm base-e units; ${ }^{\circ} \mathrm{C}$, degrees Celsius; --, not calculated]

\begin{tabular}{|c|c|c|c|}
\hline & \multicolumn{3}{|c|}{ Subreach number } \\
\hline & 1 & 2 & 3 \\
\hline Dye-recovery ratio ( $\boldsymbol{J}$ (upstream site to downstream site) & 1.14 & 1.11 & 1.16 \\
\hline $\begin{array}{l}\text { Gas desorption-rate coefficient }\left(\boldsymbol{K}_{\mathrm{T}} \text {, a ratio of upstream to downstream peak }\right. \\
\text { gas concentration), per hour (peak method) }\end{array}$ & .119 & .118 & .172 \\
\hline $\begin{array}{l}\text { Gas desorption-rate coefficient }\left(\boldsymbol{K}_{\mathrm{T}} \text {, a ratio of upstream to downstream total }\right. \\
\text { mass of gas), per hour (area method) }\end{array}$ & .104 & .114 & -- \\
\hline Reaeration coefficient at $20^{\circ} \mathrm{C}\left(\boldsymbol{K}_{2_{20}}\right)$, per day (peak method) & 5.55 & 5.67 & 6.70 \\
\hline Reaeration coefficient at $20^{\circ} \mathrm{C}\left(\boldsymbol{K}_{2_{20}}\right)$, per day (area method) & 4.85 & 5.47 & -- \\
\hline
\end{tabular}




\title{
DISCHARGE MEASUREMENTS IN STREAMS
}

\author{
Methods
}

USGS hydrographers have made numerous dyedilution measurements of stream discharge in Wyoming since 1967. Sometimes called dilution gaging, the technique is both simple and, if used correctly, accurate. A dye-dilution measurement is not a substitute for a current-meter measurement, but is an effective alternative when use of a current meter is either impracticable or impossible. The basic principle of dilution gaging is that the amount of dilution of an injected soluble tracer in a stream is directly proportional to the stream discharge.

There are two methods for dilution gaging. The slug-injection method requires extensive sampling and might yield less accurate results. Only the constantrate-injection method has been used in Wyoming. Both methods are described in detail by Kilpatrick and Cobb (1985). The inverse of the slug-injection calculation (using known discharge) is used to calculate dye recovery in time-of-travel and reaeration measurements and in some dye tests in karst terrane. Calculation of dye recovery is described later in the methods for investigations in karst terrane.

Theory.-When dye is injected at a constant rate into a stream or other conduit in which the discharge is approximately steady, the amount of dye passing any cross section in a unit of time is approximately constant. The amount of dye (the dye flux) is equal to the discharge in the conduit multiplied by the concentration of the dye, whether the conduit is the dye-injection tubing or the stream, canal, or pipe receiving the dye. As dye injection continues, at some point downstream the dye becomes completely mixed throughout the cross section of flow, and for some additional distance the concentration of dye is approximately the same at any point in the stream. Hydrographers refer to this as the "plateau" concentration (fig. 17).

Measurement of dye flux-hence, stream discharge - is practical only at stream cross sections where dye injection and the resulting dye concentration in the stream are in equilibrium. The equation below indicates the relation of dye flux in the stream to dye flux in the injection tubing at equilibrium. Stream discharge $\boldsymbol{Q}$ can be calculated from measurements of the other three variables (Kilpatrick and Cobb, 1985, p. 5, eq. 2):

$$
Q c=q C,
$$

where $Q$ is the stream discharge,

$\boldsymbol{C}$ is the plateau concentration in the stream, $\boldsymbol{q}$ is the injection rate, and

$\boldsymbol{C}$ is the concentration of the injection solution

Data Collection.-Various apparatus for injecting dye at a constant rate are described by Kilpatrick and Cobb (1985, p. 20-23). In Wyoming, a pressurized chemical-feed tank was used prior to 1975 , and batterydriven fluid-metering pumps thereafter. The injection rate $\boldsymbol{q}$ from the pressurized tanks was measured intermittently using a $100-\mathrm{mL}$ (milliliter) graduated cylinder held under the outflow tubing. That method has been replaced by timing the cumulative change in contents in a 1,000 or $2,000-\mathrm{mL}$ graduated cylinder from which the dye solution is pumped directly into the stream through 0.25 -inch (inside diameter) plastic tubing (fig. 18). A sample of the injection solution is retained for laboratory determination of injectionsolution concentration $\boldsymbol{C}$.

The sampling cross section is located where the discharge is to be measured. There can be inflow between the injection site and sampling site, but there should not be outflow. Several sets of samples are collected at three or more points across the stream at a fixed time interval, such as 5 minutes. The samples are retained for determination of plateau concentration $\boldsymbol{c}$. Concentrations may be expressed either in fluorometer units or in micrograms per liter.

Data Analysis. - Injection rate $\boldsymbol{q}$ is measured as described above, and concentrations $\boldsymbol{C}$ and $\boldsymbol{C}$ are determined fluorometrically. Discharge $\boldsymbol{Q}$, in cubic feet per second, with $\boldsymbol{q}$ in milliliters per minute, is calculated as follows:

$$
Q=5.89 \times 10^{-7} \frac{q C}{C} .
$$

An acceptable measurement is one with a constant injection rate, a well-defined plateau concentration (fig. 17), and nearly uniform lateral mixing (fig. 19). 

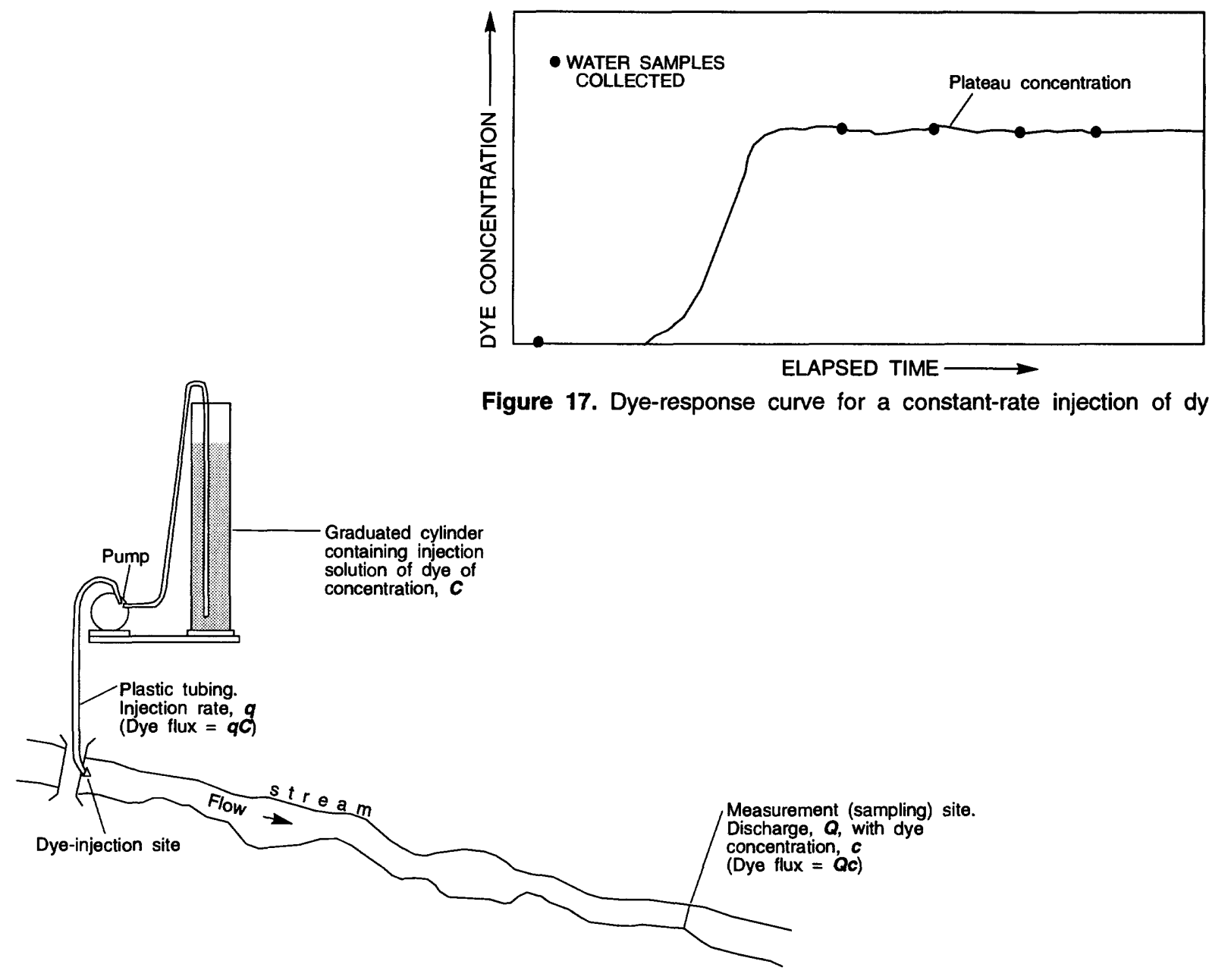

Figure 18. Injection equipment and stream reach for a dye-dilution discharge measurement.
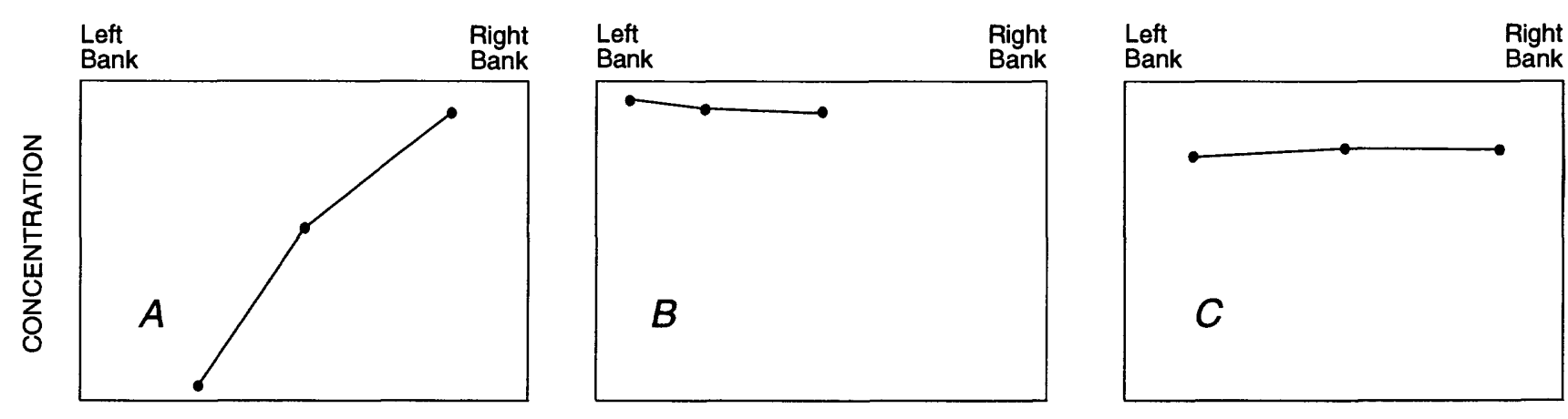

DISTANCE ACROSS STREAM

Figure 19. Degrees of lateral mixing for dye-dilution discharge measurements. Dots indicate samples. $A$, poor mixing (therefore, poor measurement); $B$, mixing uncertain because sampling did not extend across stream (measurement considered poor); $C$, excellent mixing (measurement can be used with confidence if injection rate was constant, and a plateau was achieved). 


\title{
DISCHARGE MEASUREMENTS IN STREAMS-Continued
}

\author{
Laramie River under Ice, 1967
}

\section{[Investigation as part of the U.S. Geological Survey Surface-Water Research Program]}

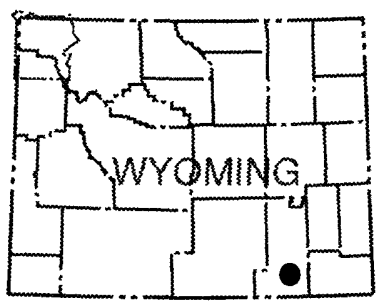

The first dye-dilution discharge measurements in Wyoming were made as part of USGS research to develop procedures for using the technique in streams covered with ice. Frederick A. Kilpatrick, USGS, Fort Collins, Colo., assisted by James G. Rankl, USGS, Cheyenne, Wyo., made five test measurements of discharge in the ice-covered Laramie River at Laramie, Wyo. (fig. 20) during February 1967. The previous year Kilpatrick had made a preliminary measurement under ice at a site on the Laramie River near

Glendevey, Colo. That test had demonstrated that loss of dye by sorption on the bottom surface of the ice was negligible. The following information is drawn from an informal report on the 1967 measurements, prepared by Kilpatrick (written commun., 1967) for administrative use within the USGS.

Data Collection.-Two measurements were made on February 17, and three on February 28, 1967. An injection solution of dye, water, and antifreeze was used for each of the first four test measurements. For the fifth measurement, only dye and water were used. A pressurized chemical-feed tank (fig. 21) was used to inject the dye solutions at a constant rate through the ice at a point in mid-channel, about 200 feet upstream from the gaging station (fig. 20). The plastic feed line from the tank was passed through a metal pipe inserted through the ice to a point at about two-thirds of the depth of the water.

For sampling, 0.5 -inch diameter holes were drilled with a carpenter's brace. The ice was about 18 inches thick. Samples were collected at each of five points across the stream (fig. 20), 50 minutes after start of injection. Water was drawn through a plastic tube inserted in the holes, then transferred to small bottles for fluorometric analysis later.

A current-meter measurement was made each day at a section of stream cleared of ice (fig. 20). Also, a detailed measurement of the vertical distribution of velocity was made February 28 . That test verified that upstream ice cover did not affect the distribution of flow at the measurement site. Mean velocity in the vertical-velocity measurement occurred at the standard depth ( 0.6 times total depth) at which the meter usually is placed.

Results. - The test measurements are summarized in table 4. Kilpatrick noted that because the viscosity of each injection solution was different, the injection rates for a given setting on the pressurized chemical-feed tank were different. For measurements 2-5, however, injection rates were constant and dye losses negligible. The calculated discharge for each of the four tests was within 2 percent of the discharge measured with a current meter (table 4). In contrast, the injection rate for measurement 1 was erratic, and dye loss was large; the calculated discharge was 11 percent greater than that measured with a meter. From these tests, Kilpatrick and Cobb (1985, p. 39) suggest that commercial antifreezes not be used for measurements under ice; laboratory-grade methanol works best. Environmental concerns, however, might preclude any future use of methanol or antifreeze in Wyoming streams.

The main conclusions from the Laramie River test measurements are that discharge under ice can be measured accurately using dye dilution, and that some antifreeze additives can be used in the injection solution without affecting measurement accuracy. The chemical-feed injection tank worked well in freezing temperatures. The dye-injection and sampling methods also worked well. Kilpatrick and Cobb (1985, p. 37-40) used the knowledge gained from these tests in their manual on dilution gaging. 


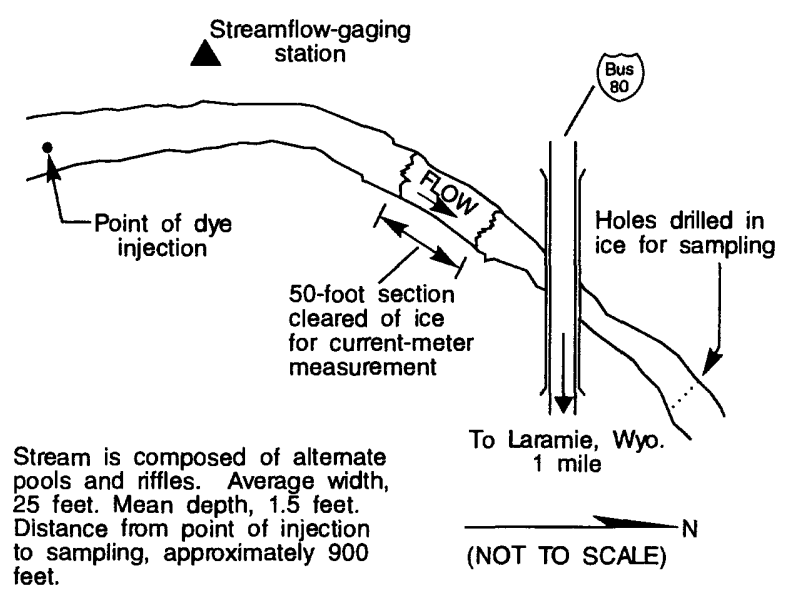

Figure 20. Sketch of the test reach for dye-dilution discharge measurements under ice, Laramie River.

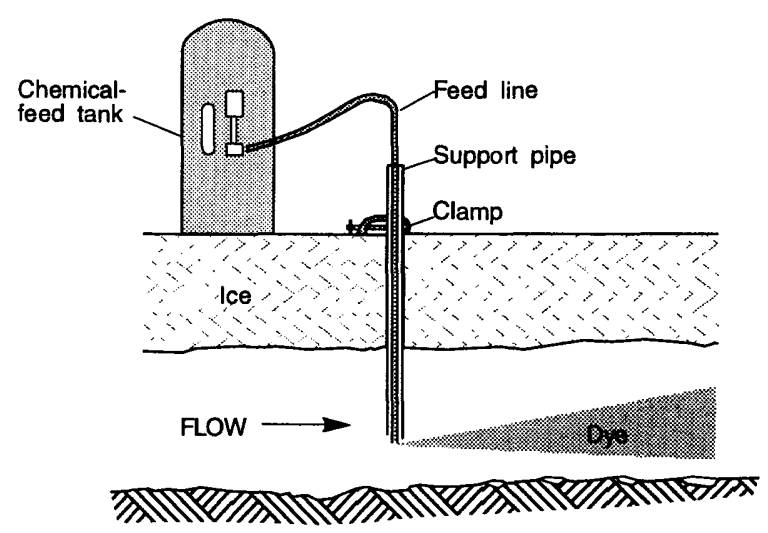

Figure 21. Longitudinal section showing setup for injecting dye through ice, Laramie River.

Table 4. Dye-dilution discharge measurements under ice cover, Laramie River at Laramie, Wyoming, February 1967

[From F.A. Kilpatrick, U.S. Geological Survey, written commun., 1967. $\mathrm{ft}^{3} / \mathrm{s}$, cubic feet per second]

\begin{tabular}{|c|c|c|c|c|c|c|}
\hline \multirow[b]{2}{*}{$\begin{array}{c}\text { Measure- } \\
\text { ment } \\
\text { number }\end{array}$} & \multirow[b]{2}{*}{ Date } & \multirow[b]{2}{*}{$\begin{array}{l}\text { Antifreeze used } \\
\text { (25 percent of solution } \\
\text { in measurements 1-4) }\end{array}$} & \multicolumn{3}{|c|}{ Stream discharge } & \multirow[b]{2}{*}{ Remarks } \\
\hline & & & $\begin{array}{c}\text { Current } \\
\text { meter } \\
\left(\mathrm{ft}^{3} / \mathrm{s}\right)\end{array}$ & $\begin{array}{c}\text { Dye } \\
\text { dilution } \\
\left(\mathrm{ft}^{3} / \mathrm{s}\right)\end{array}$ & $\begin{array}{l}\text { Percent } \\
\text { difference }\end{array}$ & \\
\hline 1 & $2-17-67$ & $\begin{array}{l}\text { Commercial glycol-base } \\
\text { antifreeze with rust inhibi- } \\
\text { tors and magnetic film addi- } \\
\text { tives }\end{array}$ & 34.0 & 37.7 & +11 & $\begin{array}{l}\text { Substantial dye loss. In a laboratory test, this } \\
\text { solution coated glassware. Inside of the injec- } \\
\text { tion tank also was coated. Additives appar- } \\
\text { ently caused large adsorptive losses under ice } \\
\text { and adversely affected the injection rate. }\end{array}$ \\
\hline 2 & $2-17-67$ & Laboratory-grade methanol & 34.0 & 34.5 & +1.5 & $\begin{array}{l}\text { Initial specific gravity of this solution was less } \\
\text { than } 1 \text {, so it tended to float until sufficiently } \\
\text { diluted by the stream. Best to use under hard } \\
\text { ice, to minimize possible adsorptive loss, } \\
\text { although such loss was not apparent in this } \\
\text { measurement. }\end{array}$ \\
\hline 3 & $2-28-67$ & $\begin{array}{l}\text { Commercial methanol-base } \\
\text { antifreeze }\end{array}$ & 32.6 & 32.8 & +0.6 & Same as measurement 2 . \\
\hline 4 & $2-28-67$ & $\begin{array}{l}\text { Laboratory-grade glycol } \\
\text { solution }\end{array}$ & 32.6 & 33.0 & +1.2 & $\begin{array}{l}\text { Initial specific gravity of this solution was } \\
\text { greater than } 1 \text {, so it tended to sink until suffi- } \\
\text { ciently diluted by the stream. Best to use } \\
\text { under soft or broken ice. Has low volatility, so } \\
\text { probably would store well as a stock solution. }\end{array}$ \\
\hline 5 & $2-28-67$ & None & 32.6 & 33.2 & +1.8 & Limited to air temperatures above freezing. \\
\hline
\end{tabular}




\title{
DISCHARGE MEASUREMENTS IN STREAMS-Continued
}

\author{
North and South Brush Creeks, 1967-68 \\ Physical Setting
}

[Investigation in cooperation with the Wyoming State Engineer]

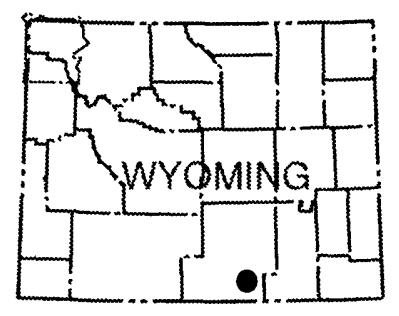

As a result of concerns of USGS hydrographers in Wyoming about the accuracy of stage-discharge ratings at streamflow-gaging stations on mountain streams, an investigation into the use of dye-dilution measurements was conducted during 1967-68. Dyetracing equipment and supplies were purchased in 1967. Eight dye-dilution discharge measurements were made at station 06622700, North Brush Creek near Saratoga, and nine at station 06622900, South Brush Creek near Saratoga (fig. 22). This was the first use of modern dye-tracing techniques by personnel of the Wyoming District, USGS.

North and South Brush Creeks have similar hydrologic and hydraulic characteristics, except that the channel of North Brush Creek has a larger widthdepth ratio than the channel of South Brush Creek. Therefore, lateral mixing is more difficult to achieve on North Brush Creek. Both streams drain an area underlain by a thick sequence of meta-sedimentary rocks of
Precambrian age. During spring snowmelt runoff, both streams transport large amounts of coarse sediments ranging in size from gravel to boulders.

North Brush Creek has a wide, shallow channel consisting mainly of gravel and boulders. The widthdepth ratio of the channel is 50 (fig. 23). A pool-riffle flow regime exists to a maximum discharge of about $25 \mathrm{ft}^{3} / \mathrm{s}$, above which flow becomes increasingly channel-controlled. Because of the boulders, shallow depth, and high velocities, most current-meter measurements are rated fair to poor for most flows that can be waded. Flows larger than $350 \mathrm{ft}^{3} / \mathrm{s}$ are measured from the bridge with reel and cable. Accurate depths are difficult to obtain with a sounding weight because of the roughness of the channel. Because of the difficulty of obtaining accurate current-meter measurements, the suitability of dye-dilution measurements was investigated.

The channel of South Brush Creek near the streamflow-gaging station is incised into coarse alluvium. The channel consists mainly of rocks and boulders, and has a width-depth ratio of 16.7 (fig. 24), in contrast with the ratio of 50 for North Brush Creek (fig. 23). The channel has few pools at any stage, except for the gage pool. The control for low flows is a riffle about 15 feet downstream from the gage. At high flows, backwater from a culvert located 100 feet downstream from the gage submerges the riffle. 


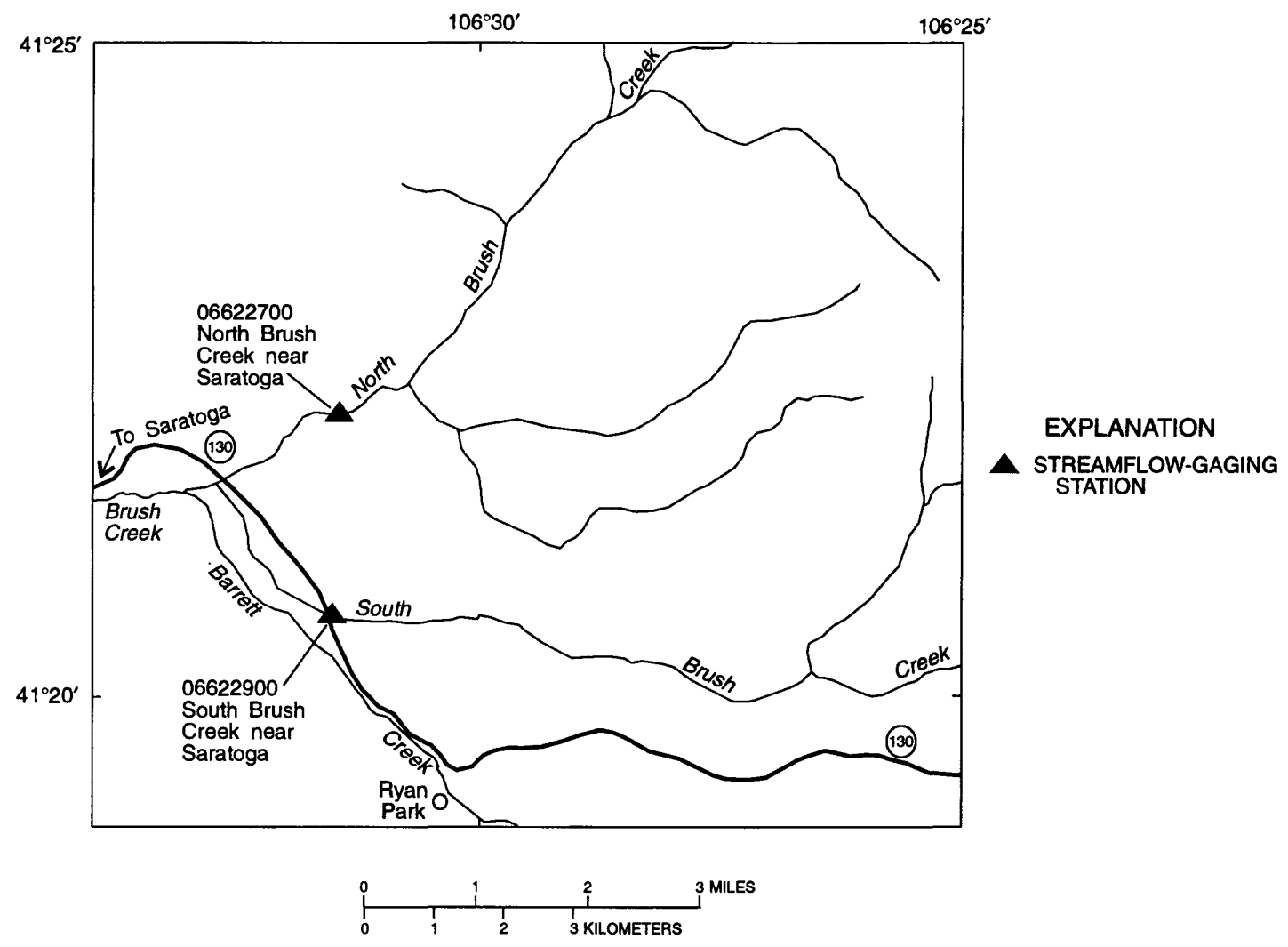

Figure 22. Location of streamflow-gaging stations on North and South Brush Creeks. Stations are approximately 16 miles southeast of Saratoga, Wyoming.

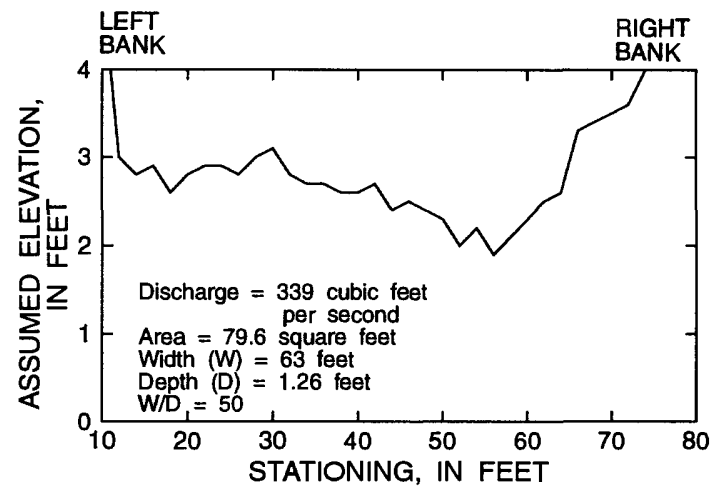

Figure 23. Typical cross section of channel of North Brush Creek.

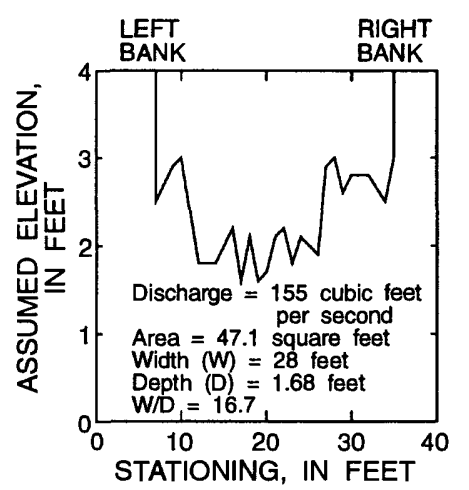

Figure 24. Typical cross section of channel of South Brush Creek. 


\title{
DISCHARGE MEASUREMENTS IN STREAMS-Continued
}

\author{
North and South Brush Creeks, 1967-68-Continued \\ Data Collection
}

North Brush Creek.-A pressurized chemicalfeed tank was used to inject the dye solution at a constant rate. For discharges less than $25 \mathrm{ft}^{3} / \mathrm{s}$, a singlepoint injection was used. A two-point injection system was used for discharges between 25 and $100 \mathrm{ft}^{3} / \mathrm{s}$. A brass $\mathrm{T}$-fitting was placed in the injection line leading from the chemical-feed tank. Two plastic tubes connected to the T-fitting were placed over the stream at points representing approximately one-half the estimated discharge.

For discharges greater than $100 \mathrm{ft}^{3} / \mathrm{s}$, a 20-point injection system was designed (fig. 25). Twenty-one feet of 3/4-inch steel pipe was suspended above the stream at a site about 600 feet upstream from the streamflow-gaging station. One-quarter-inch diameter holes were drilled into the pipe at 1 -foot intervals. One end of the pipe was capped and the other was attached to the discharge hose from a centrifugal pump. Dye was injected into the intake side of the centrifugal pump from the pressurized chemical-feed tank through a brass fitting. Water was pumped from the stream, mixed with dye in the pump, and discharged to the stream through the 3/4-inch perforated pipe.

To determine the adequacy of lateral mixing, water samples were collected at three points across the stream (at the quarter-points of flow). For discharges less than $25 \mathrm{ft}^{3} / \mathrm{s}$, mixing was accomplished by injecting at a site at least two pool-riffle sequences upstream from the sampling site. For discharges greater than $100 \mathrm{ft}^{3} / \mathrm{s}$, mixing was achieved by using the aforementioned dye-injection system (fig. 25). Water samples for discharges greater than $100 \mathrm{ft}^{3} / \mathrm{s}$ were collected from the U.S. Forest Service bridge about 200 feet upstream from the gage.
The degree of lateral and longitudinal mixing was evaluated to determine the adequacy of dyedilution discharge measurements on North Brush Creek. Data from a measurement made October 6, 1967 were used to make the evaluation. A 0.2-percent solution of rhodamine WT dye was injected into the stream for about 1 hour. The dye-response curve is shown in figure 26. Dye concentration on the plateau increased, owing to a slight increase in the dyeinjection rate. Because the streamflow was constant, averages of the injection rates and the fluorometer readings were used to calculate the stream discharge. Lateral variation in concentration was about 7 percent, and the variation in discharge from four sets of quarterpoint samples was 1.6 percent.

South Brush Creek.-A pressurized chemicalfeed tank also was used for dye injections in South Brush Creek. For all measurements, dye was injected at a single point in mid-stream, about 300 feet upstream from the gage. Water samples for dye concentration were collected at the downstream end of a culvert about 150 feet downstream from the gage. Flow through the culvert facilitated mixing of the dye.

Data from a measurement made October 6, 1967 were used to evaluate the adequacy of dye-dilution discharge measurements made on South Brush Creek. A 0.2-percent solution of rhodamine WT dye was injected into South Brush Creek for about 1 hour. Water samples were collected at five points across the channel. The dye-response curve for the measurement is shown in figure 27. The dye concentrations were weighted by the percentage of the estimated discharge for each segment. The lateral variation in concentration was 1.4 percent and the spread in discharge calculated from two sets of samples was 1.8 percent. 


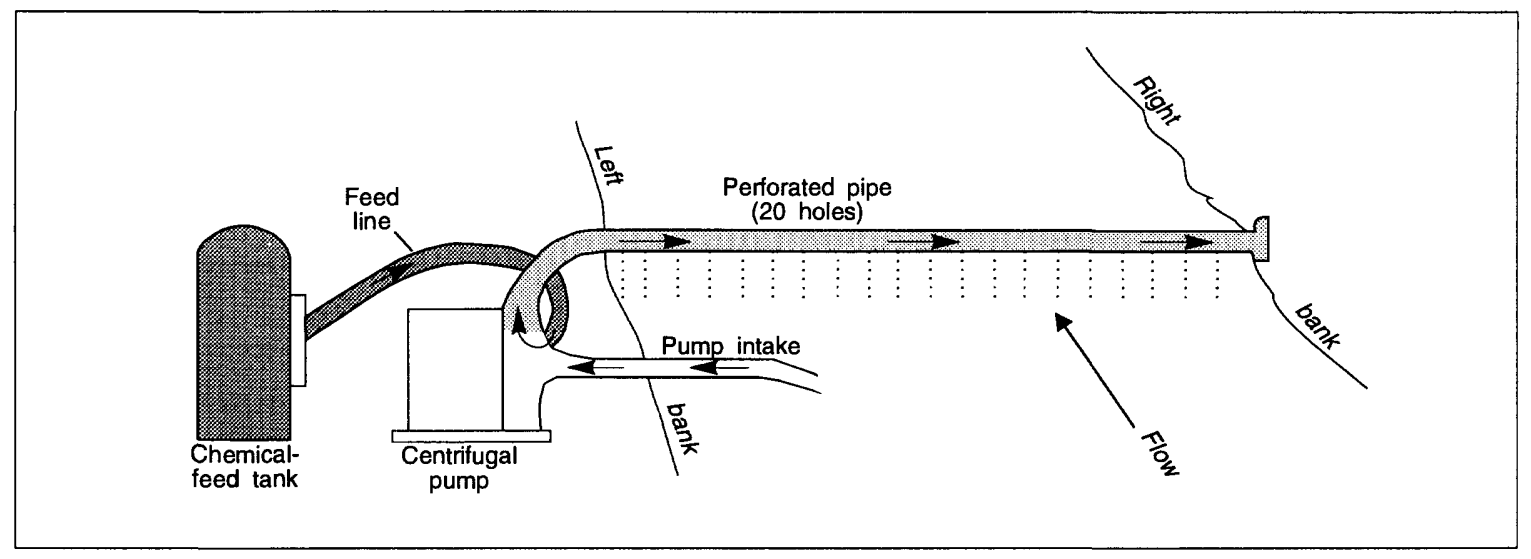

Figure 25. Sketch of dye-injection equipment used for high-flow discharge measurements in North Brush Creek.

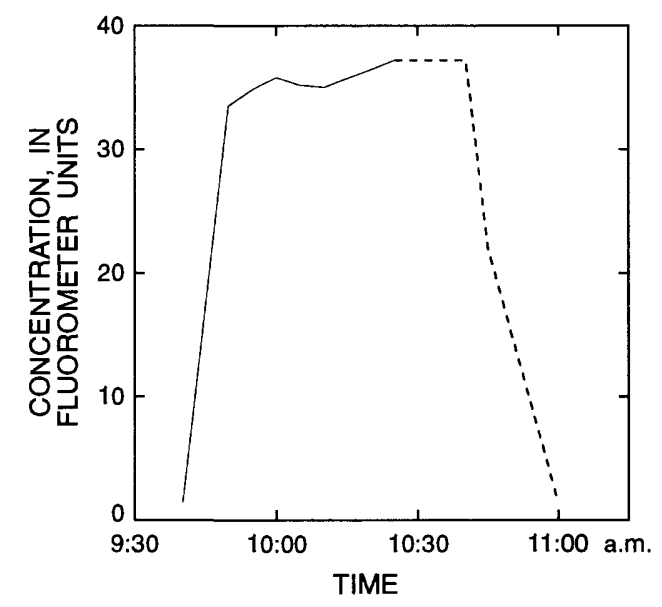

Figure 26. Dye-reponse curve for dye-dilution discharge measurement of October 6, 1967 in North Brush Creek. Dashed line indicates approximate shape of curve after dye injection ceased (no samples collected).

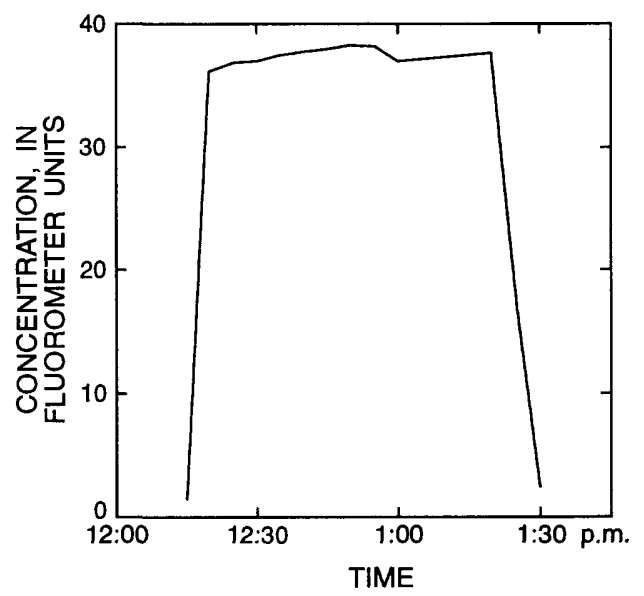

Figure 27. Dye-response curve for dye-dilution discharge measurement of October 6, 1967 in South Brush Creek. 


\title{
DISCHARGE MEASUREMENTS IN STREAMS-Continued
}

\author{
North and South Brush Creeks, 1967-68-Continued
}

\author{
Results
}

All dye-dilution discharge measurements made in North and South Brush Creeks are listed in table 5. The use of these measurements in defining stagedischarge relations is described below.

North Brush Creek.-A stage-discharge relation using all open-water current-meter and dyedilution measurements for water years 1967-69 is shown in figure 28 . The rating is fairly well defined, except for discharges in the transition between the pool-riffle flow regime and the channel-flow regime. Adequate mixing during the last dye-dilution measurement (no. 105, table 5) was not achieved; therefore, that measurement was not used in developing the stage-discharge relation.

South Brush Creek.-All open-water measurements made on South Brush Creek near Saratoga for water years 1966-68 were used to evaluate stage-discharge ratings and the results of the dyedilution measurements. The maximum daily discharge for water year 1968 was $393 \mathrm{ft}^{3} / \mathrm{s}$, a flow that is exceeded less than 1 percent of the time (Peterson, 1988, p. 286). The high flow caused channel erosion and a substantial change in the stage-discharge relation (fig. 29). Because hydrologists working the 1968 record lacked confidence in dye-dilution measurements, a new rating based on the dye measurements was not developed. However, a new rating (rating no. 6, fig. 29) was developed for water year 1969, after additional current-meter measurements had been obtained. Rating no. 6 was nearly identical to a temporary rating (not shown in fig. 29) based on the six dye-dilution measurements and one current-meter measurement made after the 1968 flood, thus confirming the accuracy of the dyedilution measurements.

Table 5. Dye-dilution discharge measurements at streamflow-gaging stations 06622700 , North Brush Creek near Saratoga, Wyoming, and 06622900, South Brush Creek near Saratoga, Wyoming, 1967-68

[ft, feet; $\mathrm{ft}^{3} / \mathrm{s}$, cubic feet per second]

\begin{tabular}{|c|c|c|c|c|c|c|c|c|c|}
\hline \multicolumn{5}{|c|}{ North Brush Creek } & \multicolumn{5}{|c|}{ South Brush Creek } \\
\hline $\begin{array}{c}\text { Measure- } \\
\text { ment } \\
\text { number }\end{array}$ & Date & Party & $\begin{array}{c}\text { Gage } \\
\text { height } \\
\text { (ft) }\end{array}$ & $\begin{array}{c}\text { Discharge } \\
\left(\mathrm{ft}^{3} / \mathrm{s}\right)\end{array}$ & $\begin{array}{c}\text { Measure- } \\
\text { ment } \\
\text { number }\end{array}$ & Date & Party & $\begin{array}{c}\text { Gage } \\
\text { height } \\
\text { (ft) }\end{array}$ & $\begin{array}{c}\text { Discharge } \\
\left(\mathrm{ft}^{3} / \mathrm{s}\right)\end{array}$ \\
\hline 93 & $9-11-67$ & Rankl, Stewart & 2.67 & 12.8 & 93 & $9-11-67$ & Rankl, Stewart & 1.86 & 8.26 \\
\hline 95 & $10-6-67$ & Rankl, Stewart & 2.89 & 24.6 & 95 & $10-6-67$ & Rankl, Stewart & 2.03 & 16.1 \\
\hline 99 & $5-23-68$ & Rankl & 3.66 & 116 & 101 & $5-23-68$ & Rankl & 2.70 & 80.5 \\
\hline 101 & $6-13-68$ & Rankl, Wilson & 4.87 & 410 & 103 & $6-13-68$ & Rankl, Wilson & 3.53 & 314 \\
\hline 102 & $7-17-68$ & Rankl & 3.20 & 56.6 & 104 & $6-13-68$ & Rankl, Wilson & 3.56 & 324 \\
\hline 103 & $8-12-68$ & Rankl & 2.90 & 24.8 & 105 & $7-16-68$ & Rankl & 2.59 & 74.1 \\
\hline 104 & $9-13-68$ & Rankl, McCollam & 2.67 & 11.3 & 106 & $8-12-68$ & Rankl & 2.08 & 24.7 \\
\hline \multirow[t]{2}{*}{105} & $10-4-68$ & Stewart & 2.68 & 9.95 & 107 & $9-13-68$ & Rankl, McCollam & 1.74 & 8.26 \\
\hline & & & & & 108 & $10-4-68$ & Stewart & 1.73 & 7.27 \\
\hline
\end{tabular}




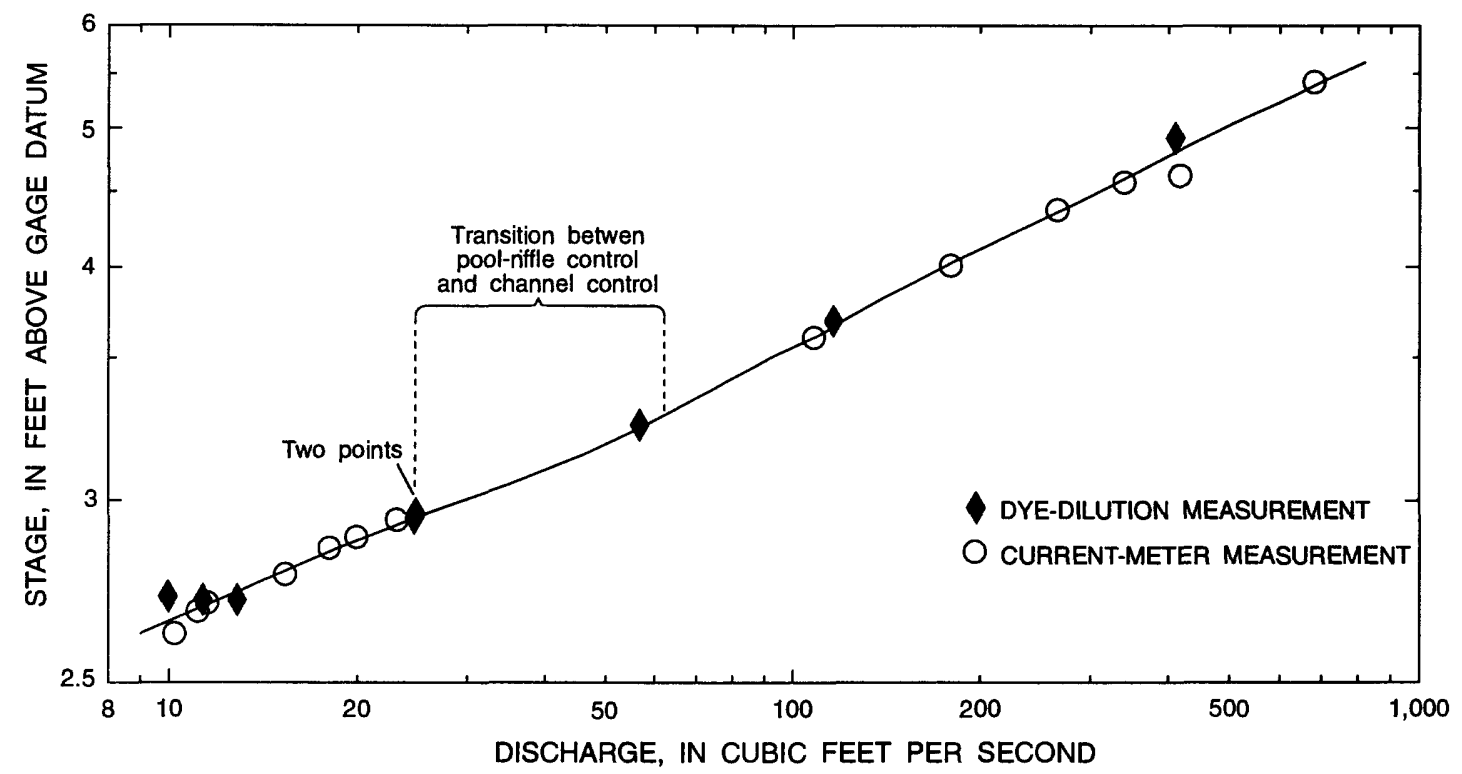

Figure 28. Stage-discharge relation for streamflow-gaging station 06622700 , North Brush Creek near Saratoga, Wyoming.

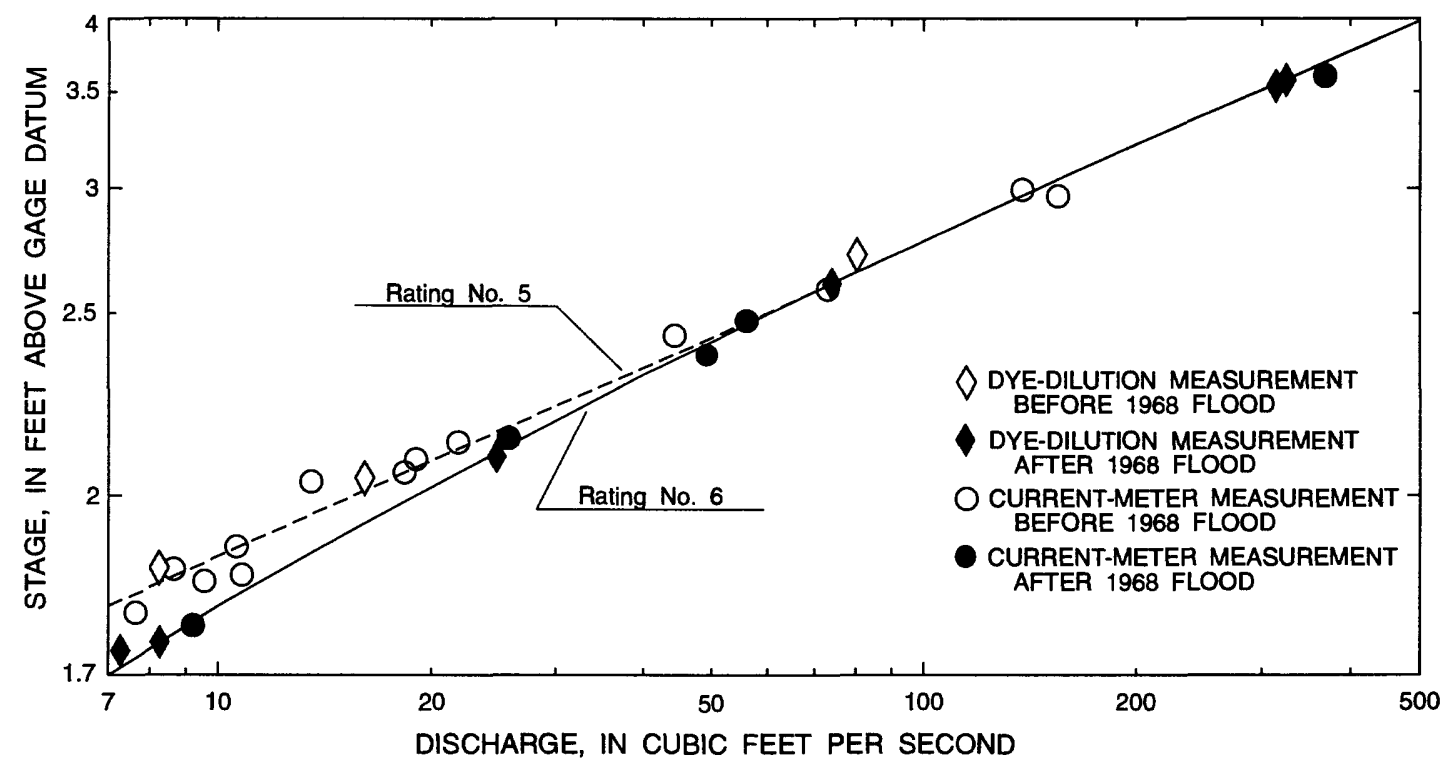

Figure 29. Stage-discharge relation for streamflow-gaging station 06622900 , South Brush Creek near Saratoga, Wyoming. 


\title{
DISCHARGE MEASUREMENTS IN STREAMS-Continued
}

\author{
South Piney Creek, 1971-78
}

[Investigation in cooperation with the Wyoming State Engineer and the Old West Regional Commission]

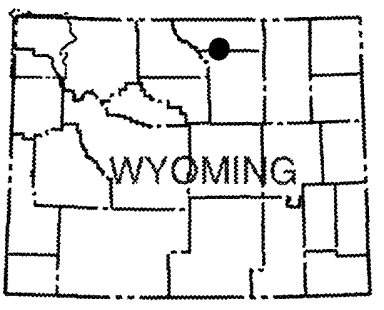

The successful application of dye-dilution procedures for measuring discharge in North and South Brush Creeks led to use of the technique in South Piney Creek. At streamflow-gaging station 06321000, South Piney Creek near Story, Wyo. (fig. 30), the channel is steep, and the stream bed is composed mainly of boulders. High flows are swift and turbulent, commonly moving boulders along the streambed beneath the cableway. High-water measurements with a current meter are extremely difficult; as is typical of such conditions, measurement accuracy is a concern.

The dye-dilution discharge measurements are listed in table 6. The first four were made by Hugh W. Lowham, USGS, Worland, with assistance from other
USGS or State Engineer personnel. The last four measurements were made by personnel of the USGS Casper and Buffalo offices as part of the Madison Limestone recharge study, described subsequently (this station is site 22 in Glass and Sultz, 1992).

A pressurized chemical-feed tank was used for the constant-rate injection for the four measurements prior to 1975 , and a small battery-operated fluidmetering pump was used thereafter. For all measurements, dye was injected 0.25 mile upstream from the gage, and samples were collected from the cableway 200 feet downstream from the gage. Lateral mixing for most measurements was excellent.

All eight dye-dilution measurements and all current-meter measurements greater than $100 \mathrm{ft}^{3} / \mathrm{s}$ made between June 1971 and July 1978 are plotted in figure 31. The stage-discharge curve in use for most of the period covered by the dye-dilution measurements also is plotted on the graph. Because the channel changed noticeably during high flows, much of the scatter of data points in figure 31 likely is the result of movement of boulders (H.W. Lowham, USGS, written commun., 1995).

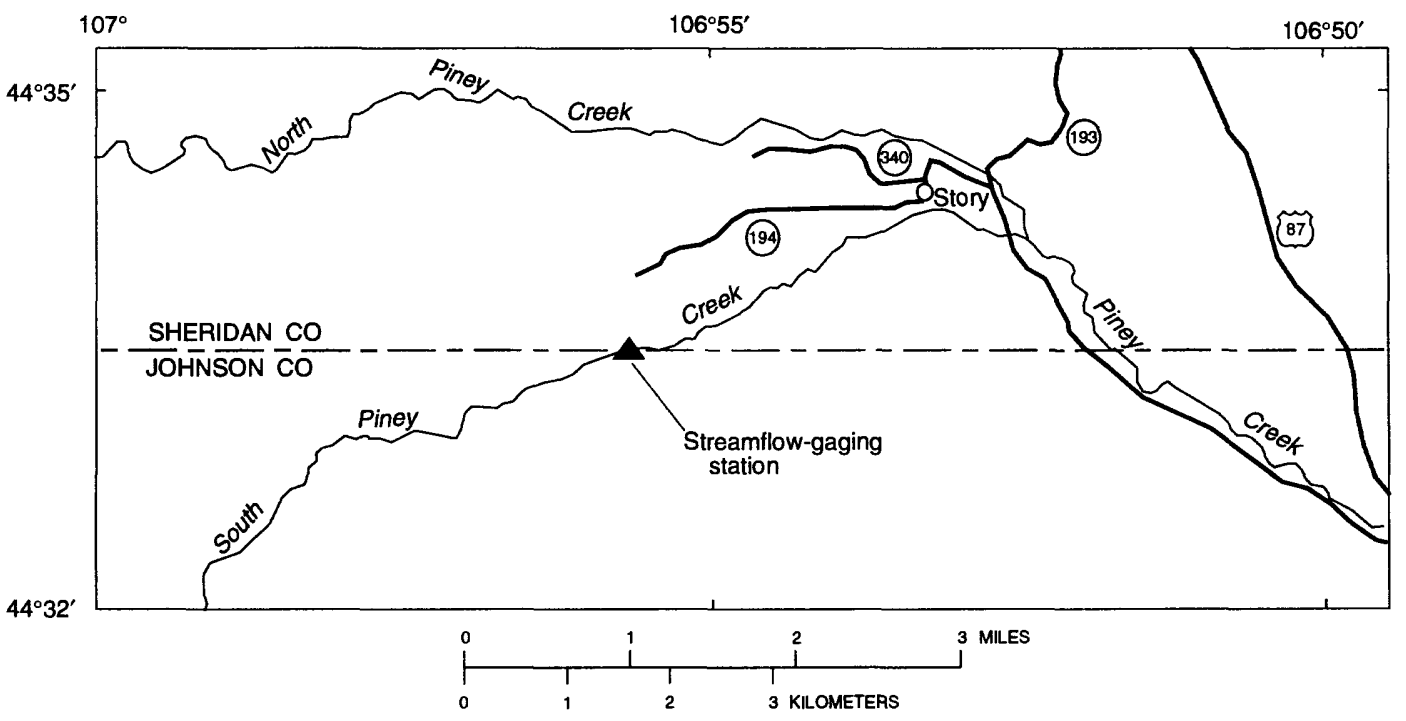

Figure 30. Location of streamflow-gaging station 06321000, South Piney Creek near Story, Wyoming. 
Table 6. Dye-dilution discharge measurements at streamflow-gaging station 06321000, South Piney Creek near Story, Wyoming, 1971-78

[ft, feet; $\mathrm{ft}^{3} / \mathrm{s}$, cubic feet per second]

\begin{tabular}{|c|c|c|c|c|c|}
\hline $\begin{array}{c}\text { Measure- } \\
\text { ment } \\
\text { number }\end{array}$ & Date & Party & $\begin{array}{c}\text { Gage } \\
\text { height } \\
\text { (ft) }\end{array}$ & $\begin{array}{l}\text { Discharge } \\
\left(\mathrm{ft}^{3} / \mathrm{s}\right)\end{array}$ & Remarks \\
\hline 289 & $6-15-71$ & Lowham, Smalley & 3.54 & 567 & $\begin{array}{l}\text { Injection rate constant; lateral mixing excellent; plateau well- } \\
\text { defined. }\end{array}$ \\
\hline 295 & $7-1-72$ & Lowham, Kawulok & 3.01 & 185 & $\begin{array}{l}\text { Injection rate constant; lateral mixing excellent; plateau fairly } \\
\text { well-defined. }\end{array}$ \\
\hline 299 & $6-13-73$ & Lowham, Leavitt & 3.73 & 696 & $\begin{array}{l}\text { Injection rate decreased during sampling; lateral mixing } \\
\text { excellent. Average of two sets of injection measurements and } \\
\text { samples used to calculate discharge. }\end{array}$ \\
\hline 308 & $6-19-74$ & Lowham, Englert & 3.40 & 576 & $\begin{array}{l}\text { Chemical-feed tank operating poorly; dye-injection rate } \\
\text { decreased during measurement. }\end{array}$ \\
\hline 324 & $7-1-75$ & Glass & 3.40 & 456 & $\begin{array}{l}\text { Injection rate constant; lateral mixing uneven; plateau fairly } \\
\text { well-defined. }\end{array}$ \\
\hline 325 & $7-7-75$ & Glass & 3.48 & 720 & $\begin{array}{l}\text { Very turbulent flow. Injection rate constant; lateral mixing and } \\
\text { plateau not verified (only two sets of samples at only two points } \\
\text { in cross section). }\end{array}$ \\
\hline 350 & $6-14-77$ & Polinoski & 2.95 & 208 & $\begin{array}{l}\text { Injection rate constant; lateral mixing fair to poor; plateau well- } \\
\text { defined. }\end{array}$ \\
\hline 363 & $7-7-78$ & Polinoski, Pedersen & 3.36 & 323 & $\begin{array}{l}\text { Injection rate decreased approximately } 3 \text { percent during } \\
\text { sampling. Lateral mixing excellent; plateau well-defined. }\end{array}$ \\
\hline
\end{tabular}

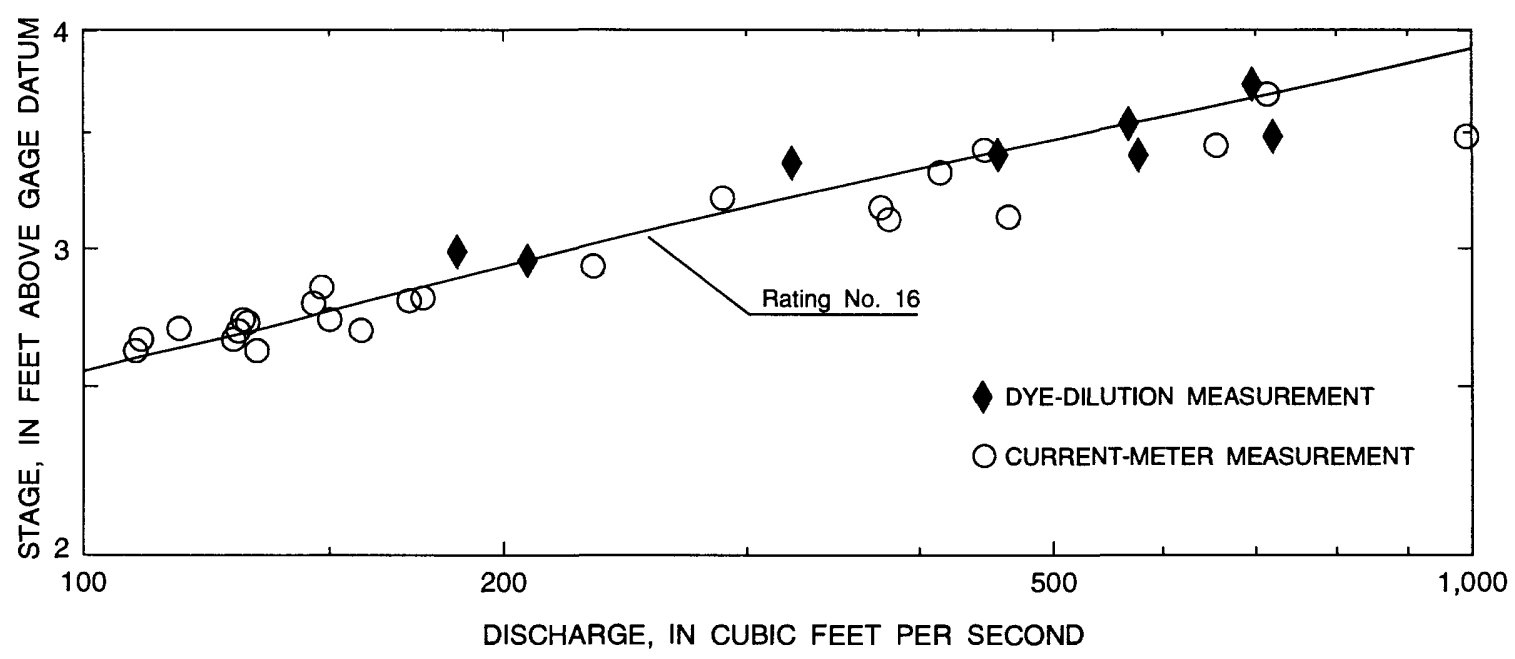

Figure 31. Stage-discharge relation for streamflow-gaging station 06321000 , South Piney Creek near Story, Wyoming. All measurements greater than 100 cubic feet per second during water years 1971-78 are plotted. 


\title{
DISCHARGE MEASUREMENTS IN STREAMS-Continued
}

\author{
Madison Limestone Recharge Study, 1975-78 \\ Data Collection
}

[Investigation in cooperation with the Wyoming State Engineer and the Old West Regional Commission]

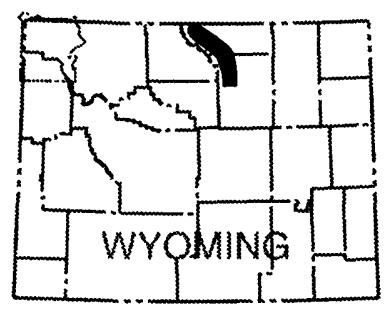

In 1975 USGS hydrographers in Wyoming were faced with the problem of making high-water discharge measurements at several new streamflow-gaging stations having no cableways or bridges. Stations had been installed in pairs on streams crossing outcrops of rocks of Paleozoic age-mainly the Madison Limestone of Mississippian age-in northeastern Wyoming (Boner and others, 1976). The purpose of the study was to obtain data for estimating streamflow recharge of the aquifer. Results are summarized by Glass and Sultz (1992). Most of the stations were at remote sites on mountain streams where access is difficult.

During 1975-78 dye-dilution techniques were used to measure discharge too high for a current-meter measurement by wading. Equipment and samples had to be compact and lightweight for backpacking to and from these remote sites. Procedures had to be simple and accurate. The location of sites at which one or more dye-dilution measurements were made is shown in figure 32.

Field Procedures. - The injection solution was prepared at the site by mixing a pre-measured amount of rhodamine WT dye with water from the stream. The amounts of dye and water to mix for the estimated stream discharge were determined onsite using guidelines prepared specifically for these measurements. A sample of the injection solution was retained for accurate determination of concentration later. A typical injection solution was 1 part dye ( 20 percent by weight) to 5 parts final solution, or a concentration of 4 percent dye by weight, or 0.04 .
Constant-rate injection of dye was achieved with a battery-operated fluid-metering pump. The injection rate, set for the estimated stream discharge, was spotmeasured using a stopwatch and a small graduated cylinder held under the outflow tubing. Air bubbles entrained in the 3/8-inch injection tubing used through 1978 sometimes affected the injection rate. The problem was eliminated for measurements after 1978 by using $1 / 4$-inch tubing.

Samples were collected at three points across the stream, where possible, to assess lateral mixing. Four or five sets of samples collected 5 minutes apart were deemed sufficient to determine whether the plateau concentration had been established. Because the dye concentrations intentionally were well below visible levels, neither the status of lateral mixing nor the existence of a plateau concentration at the sampling site could be ascertained in the field. If the fluorometric results later indicated that lateral mixing was poor or that the plateau had not been achieved, the distance between the injection and sampling sites and (or) the time between start of injection and start of sampling were increased for the next measurement.

If a stream were too wide to sample across the entire width, complete lateral mixing could not be verified. Measurement accuracy was downgraded for such measurements, a few of which could not be used.

Laboratory Procedures.-An indirect calibration of the fluorometer was made for each discharge measurement to minimize work in the field. All samples were sent to the laboratory in Cheyenne, where the injection solution was diluted by a factor of $10^{7}$. The diluted solution and all stream samples were tested in a fluorometer after they had been stored for at least 1 day. Plateau concentrations generally were between 0.5 and 3 micrograms per liter. Concentrations in fluorometer units were used to calculate the stream discharge. The reading for the diluted injection solution was multiplied by the dilution factor, $10^{7}$, for the calculation. 


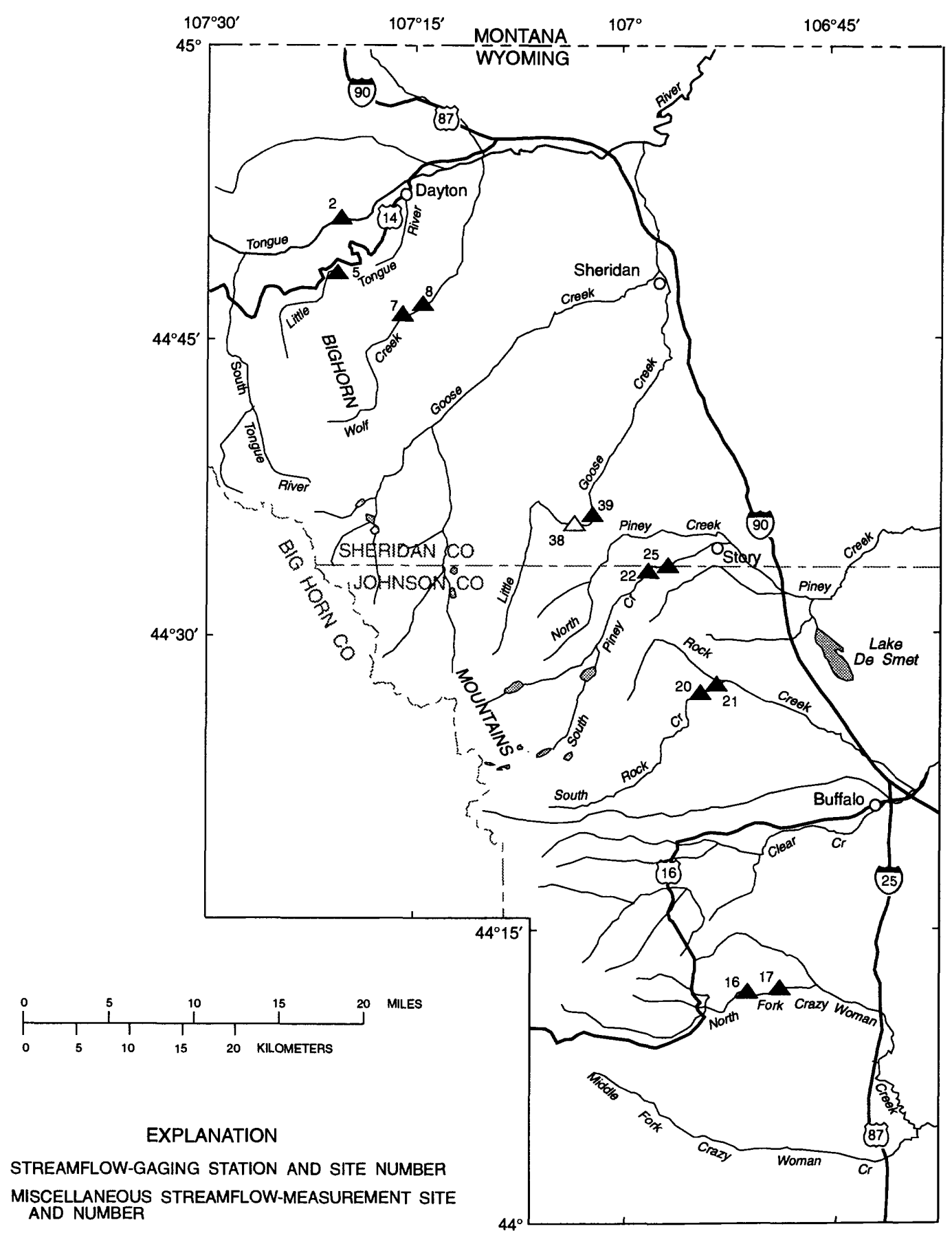

Figure 32. Location of streamflow-gaging stations and miscellaneous-measurement sites used for the Madison Limestone recharge study and at which dye-dilution discharge measurements were made during 1975-78. Site numbers are from Glass and Sultz (1992). 


\title{
DISCHARGE MEASUREMENTS IN STREAMS-Continued
}

\author{
Madison Limestone Recharge Study, 1975-78-Continued
}

Results

Results of 29 dye-dilution discharge measurements made for the Madison Limestone recharge study are listed in table 7. Unless otherwise noted under remarks, the injection rate was constant and the plateau concentration well-defined.

Most of the listed measurements were used to define the stage-discharge relation (rating curve) for the station or site. A few that otherwise appeared to be acceptable were not used because, in the judgement of the hydrographer analyzing the records, they were not consistent with other measurements. For some stations, however, the dye-dilution measurements were essential for developing the high-flow part of the curves and hence, the high-flow records for the station.

Four dye-dilution discharge measurements had been made previously at one station, South Piney Creek near Story (site 22 in Glass and Sultz, 1992; location shown on fig. 32). All dye measurements are listed in table 6 (p. 29); only the dye measurements made for the Madison Limestone recharge study are repeated in table 7 . The rating curve (fig. 31, p. 29) provides a comparison of dye-dilution measurements with current-meter measurements at this site.

The stage-discharge relation for Tongue River at Tongue Canyon Campground, near Dayton, Wyo. (site 2, fig. 32), shown in fig. 33, also provides evidence of the accuracy of the dye-dilution method.
Current-meter measurements were made from a National Forest footbridge; water samples for some of the dye measurements also were collected from that bridge. Sampling from the bridge assured accurate determination of lateral mixing, which essentially was complete for every measurement. The two largest discharges ever measured by dye dilution in Wyoming were at this station (measurements 15 and 52, table 7).

Hydrographers occasionally had difficulty in obtaining consistent spot-measurements of the injection rate. Also, the outlet tubing was too large for the small injection rates, so air bubbles in the tubing affected the measurement of the injection rate. Since the completion of the Madison Limestone recharge study, the procedure has been changed to time the cumulative volume of dye pumped from a 1- or 2-liter graduated cylinder during the cumulative injection time. Using plastic tubing with a smaller diameter solved the air-entrainment problem.

Incomplete lateral mixing at the sampling site was evident in a few measurements. Procedures have been modified to include injecting the dye closer to midstream and sampling farther downstream from the injection site. Sampling techniques also have been modified to assure collection of samples near the opposite streambank for better assessment of the extent of lateral mixing.

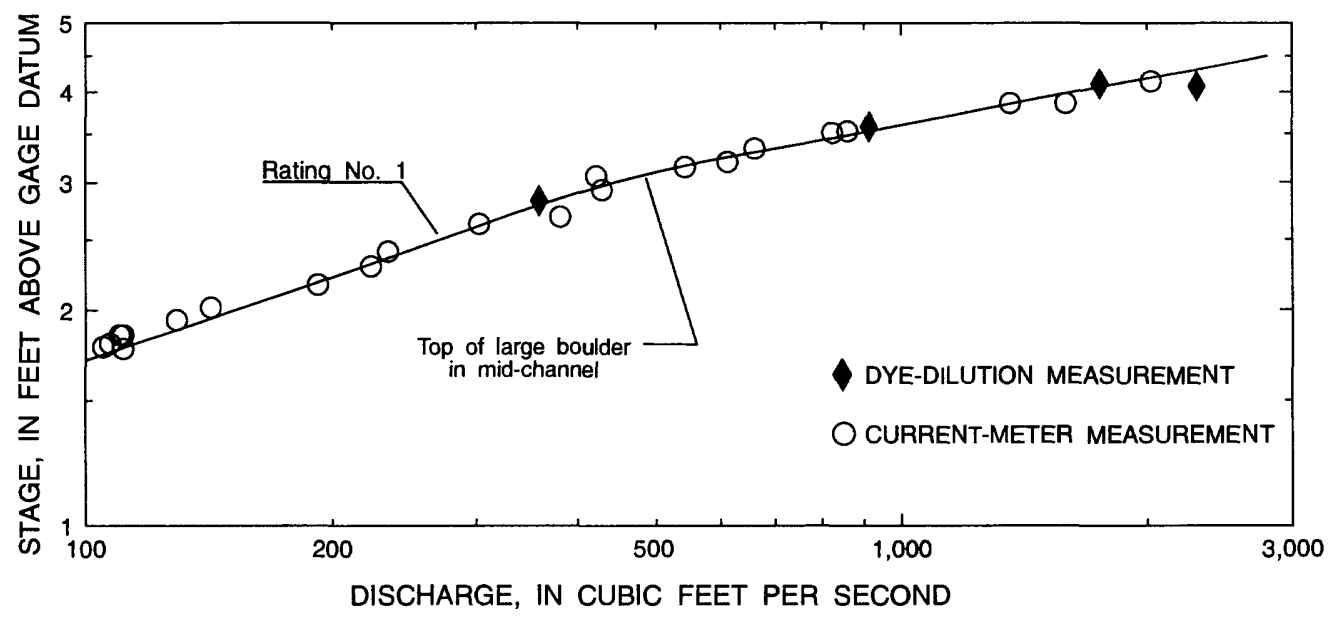

Figure 33. Stage-discharge relation for streamflow-gaging station 06297480, Tongue River at Tongue Canyon Campground, near Dayton, Wyoming (site 2, fig. 32 and table 7). All measurements greater than 100 cubic feet per second during 1975-79 are plotted. 
Table 7. Dye-dilution discharge measurements at streamflow-gaging stations and miscellaneous-measurement sites used in the Madison Limestone recharge study, northeastern Wyoming, 1975-78

[Site numbers from Glass and Sultz (1992); locations shown in figure $32 . \mathrm{ft}^{3} / \mathrm{s}$, cubic feet per second]

\begin{tabular}{|c|c|c|c|c|}
\hline $\begin{array}{c}\text { Measure- } \\
\text { ment } \\
\text { number }\end{array}$ & Date & $\begin{array}{c}\text { Discharge } \\
\left(\mathrm{ft}^{3} / \mathrm{s}\right)\end{array}$ & Party & Remarks \\
\hline \multicolumn{5}{|c|}{ Site 2-06297480 Tongue River at Tongue Canyon Campground, near Dayton, Wyo. } \\
\hline 12 & $5-22-75$ & 359 & Druse & Mixing excellent. \\
\hline 13 & $6-4-75$ & 913 & Druse & Injection rate increased slightly during sampling; mixing excellent. \\
\hline 15 & $6-24-75$ & 1,750 & Muench, Druse & Injection rate increased slightly during sampling; mixing excellent. \\
\hline 52 & $6-15-78$ & 2,300 & Polinoski, Pedersen & Injection rate decreased slightly during sampling; mixing very good. \\
\hline \multicolumn{5}{|c|}{ Site 5-06298480 Little Tongue River at Steamboat Point, near Dayton, Wyo. } \\
\hline 14 & $6-19-75$ & 159 & Druse & Mixing poor to fair. \\
\hline \multicolumn{5}{|c|}{ Site 7-06299480 Wolf Creek below Alden Creek, near Wolf, Wyo. } \\
\hline 12 & $6-5-75$ & 218 & Druse & Mixing good. \\
\hline 13 & $6-19-75$ & 271 & Druse & Mixing fair to good; plateau fluctuated. \\
\hline 14 & $6-24-75$ & 468 & Muench & Mixing excellent. \\
\hline 15 & $7-1-75$ & 217 & Druse & Mixing good. \\
\hline \multicolumn{5}{|c|}{ Site 8-06299490 Wolf Creek above Red Canyon Creek, near Wolf, Wyo. } \\
\hline 11 & $6-3-75$ & 156 & Druse & Injection rate and plateau definition erratic; mixing good. \\
\hline 12 & $6-5-75$ & 195 & Druse & Injection rate and plateau decreased slightly during sampling. \\
\hline 13 & $6-19-75$ & 265 & Druse & Mixing good. \\
\hline 14 & $7-1-75$ & 235 & Druse & Mixing good. \\
\hline \multicolumn{5}{|c|}{ Site 16-06313950 North Fork Crazy Woman Creek below Pole Creek, near Buffalo, Wyo. } \\
\hline 71 & $6-14-78$ & 219 & Polinoski, Pedersen & Mixing fair to good. \\
\hline \multicolumn{5}{|c|}{ Site 17-06314000 North Fork Crazy Woman Creek near Buffalo, Wyo. } \\
\hline 138 & $6-14-78$ & 216 & Pedersen, Polinoski & Mixing good. \\
\hline \multicolumn{5}{|c|}{ Site 20—06319470 South Rock Creek at forest boundary, near Buffalo, Wyo. } \\
\hline 13 & $6-24-75$ & 245 & Glass, Ragsdale, Peterson & Rising stage. Mixing good. \\
\hline \multicolumn{5}{|c|}{ Site 21-06319480 South Rock Creek above Red Canyon, near Buffalo, Wyo. } \\
\hline 13 & $6-27-75$ & 241 & Ragsdale, Peterson & Mixing poor. Not used for rating. \\
\hline \multicolumn{5}{|c|}{ Site 22-06321000 South Piney Creek near Story, Wyo. } \\
\hline 324 & $7-1-75$ & 456 & Glass & Lateral mixing uneven. \\
\hline 325 & $7-7-75$ & 720 & Glass & Very turbulent flow. Lateral mixing, plateau not verified. \\
\hline 350 & $6-14-77$ & 208 & Polinoski & Lateral mixing fair to poor. \\
\hline 363 & $7-7-78$ & 323 & Polinoski, Pedersen & Injection rate decreased during sampling; lateral mixing excellent. \\
\hline \multicolumn{5}{|c|}{ Site 25-06321100 South Piney Creek below Mead-Coffeen Ditch, near Story, Wyo. } \\
\hline 11 & $7-1-75$ & 414 & Glass & Mixing excellent; plateau slightly erratic. \\
\hline 12 & $7-7-75$ & 735 & Glass & Only two sets of samples at two points. \\
\hline 22 & $6-10-76$ & 708 & Muench & Mixing poor; plateau decreased and was erratic. \\
\hline 23 & $6-10-76$ & 529 & Muench & Mixing poor. \\
\hline 47 & $6-13-78$ & 368 & Polinoski & Mixing poor; plateau erratic. \\
\hline 48 & $7-7-78$ & 346 & Polinoski, Pedersen & Injection rate decreased during sampling; mixing and plateau erratic. \\
\hline \multicolumn{5}{|c|}{ Site 38-Little Goose Creek (upper site; see Glass and Sultz, 1992, p. 73) } \\
\hline & $9-24-75$ & 59.7 & Muench, Englert & Mixing excellent; plateau increased. \\
\hline \multicolumn{5}{|c|}{ Site 39-06303500 Little Goose Creek in canyon, near Big Horn, Wyo. } \\
\hline 438 & $9-24-75$ & 56.2 & Muench, Englert & Mixing excellent. \\
\hline
\end{tabular}




\title{
DISCHARGE MEASUREMENTS IN STREAMS-Continued
}

\author{
Other Measurements, 1971-82
}

In addition to the dye-dilution discharge measurements on South Piney Creek and for the Madison Limestone recharge study, USGS hydrographers made measurements during 1971, 1975-78, and 1982 at eight other streamflow-gaging stations and miscellaneous sites, most in cooperation with the Wyoming State Engineer. The site locations for these measurements are shown in figure 34; the measurements are listed in table 8 .

At least two dye-dilution measurements were made in East Fork Big Goose Creek immediately below the Park Reservoir dam (site 3, fig. 34) August 2, 1971 for use in rating the outlet (Myron E. Smalley, U.S. Geological Survey, oral commun., 1995). Current-meter measurements are extremely difficult at that site because of the rocky channel and swift current. Results of those measurements could not be located.

Training measurements were made during 1975 on the Nowood River (site 1) and Deer Creek (site 8), in preparation for the Madison Limestone recharge study. A measurement of Deer Creek in 1977 also was for training. The discharge measured by dye-dilution in 1975 was 5 percent less than the discharge measured with a current meter; the dye measurement in 1977 was 5 percent greater than the current-meter measurement.

Five high-water discharge measurements using dye were made during 1975-78 at a station on Middle Fork Powder River near Barnum (site 7). Some results were poor, because of dye-injection problems or difficulty in verifying lateral mixing (table 8 ).

On August 5, 1977, dye-dilution measurements were made at three sites on East Fork Big Goose Creek downstream from Park Reservoir (sites 4-6), in an attempt to verify an apparent loss of about $8 \mathrm{ft}^{3} / \mathrm{s}$ in a 2-mile reach downstream from Park Reservoir (Donald D. Englert, Wyoming State Engineer's Office, oral commun., 1995). The results listed in table 8 indicate a decrease of about $2 \mathrm{ft}^{3} / \mathrm{s}$ between sites 4 and 5 .

The streamflow-gaging station on Middle Creek at East Entrance, Yellowstone National Park (site 2) was operated for 3 years in cooperation with the National Park Service. The two dye-dilution discharge measurements listed in table 8 were higher than any current-meter measurements made at this station.

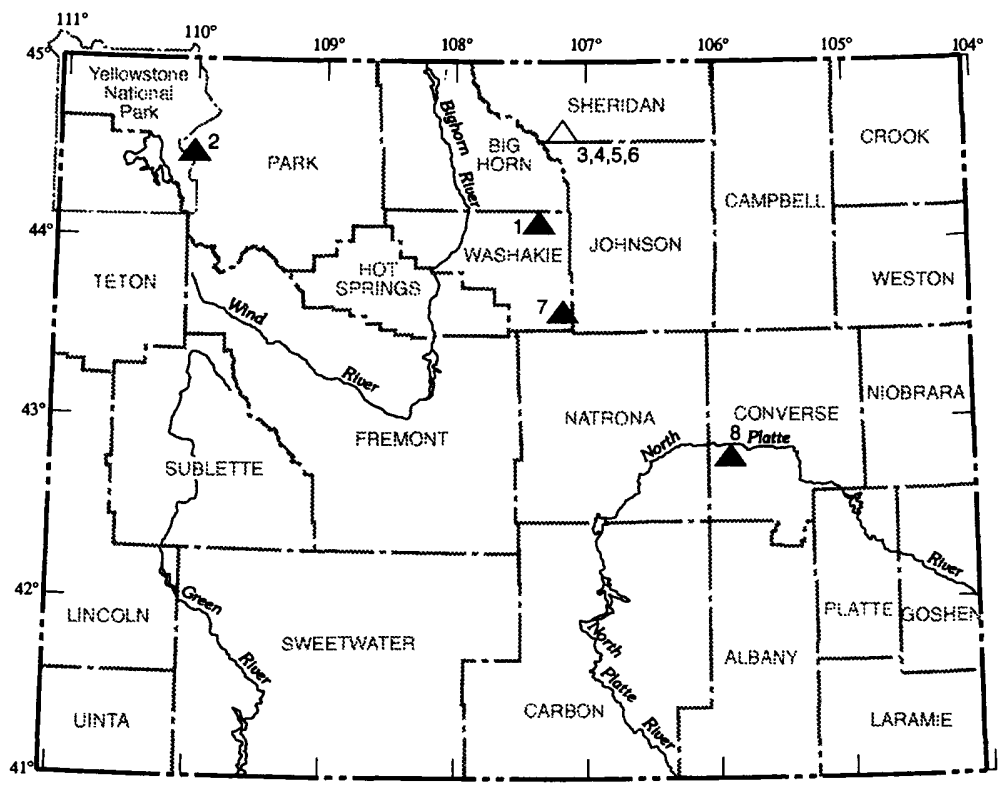

EXPLANATION

8 STREAMFLOW-GAGING STATION AND SITE 3.456 NUMBER

$\triangle$ MISCELLANEOUS STREAMFLOW MEASUREMENT SITE AND NUMBER

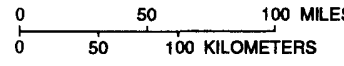

Figure 34. Location of sites where miscellaneous dye-dilution discharge measurements were made, $1971-82$. 
Table 8. Miscellaneous dye-dilution discharge measurements at streamflow-gaging stations and miscellaneousmeasurement sites in Wyoming, 1971-82

[Site locations shown in figure $34 . \mathrm{ft}^{3} / \mathrm{s}$, cubic feet per second; (?), information missing]

\begin{tabular}{|c|c|c|c|}
\hline Date & $\begin{array}{l}\text { Discharge } \\
\left(\mathrm{ft}^{3} / \mathrm{s}\right)\end{array}$ & Party & Remarks \\
\hline \multicolumn{4}{|c|}{ Site 1-06270000 Nowood River near Ten Sleep, Wyo. } \\
\hline $5-28-75$ & 846 & Druse, McCollam, Muench & $\begin{array}{l}\text { Training measurement. High sediment content may have affected } \\
\text { dye loss in samples. Mixing excellent. Calculated discharge } \\
\text { considered inconsistent with current-meter measurements of } \\
\text { similar magnitude. }\end{array}$ \\
\hline \multicolumn{4}{|c|}{ Site 2-06279850 Middle Creek at East Entrance, Yellowstone National Park, Wyo. } \\
\hline $6-21-82$ & 478 & Muench, Smalley & Mixing fair. \\
\hline $6-28-82$ & 742 & Muench, Smalley & $\begin{array}{l}\text { Highest measurement made at station; stage-discharge relation } \\
\text { drawn to this measurement. }\end{array}$ \\
\hline \multicolumn{4}{|c|}{ Site 3-East Fork Big Goose Creek immediately below Park Reservoir, near Beckton, Wyo. } \\
\hline $8-2-71$ & $(?)$ & Lowham, Smalley, (?) & At least two measurements made; results not found. \\
\hline \multicolumn{4}{|c|}{ Site 4-East Fork Big Goose Creek 0.5 mile below Park Reservoir, near Beckton, Wyo. } \\
\hline $8-5-77$ & 61.5 & $\begin{array}{l}\text { Ragsdale, Pedersen, Englert, } \\
\text { Moore }\end{array}$ & Mixing good. \\
\hline \multicolumn{4}{|c|}{ Site 5-East Fork Big Goose Creek 0.5 mile above Beaver Ditch diversion, near Beckton, Wyo. } \\
\hline $8-5-77$ & 59.3 & $\begin{array}{l}\text { Ragsdale, Pedersen, Englert, } \\
\text { Moore }\end{array}$ & Mixing good; plateau not well-defined. \\
\hline \multicolumn{4}{|c|}{ Site 6-East Fork Big Goose Creek at Beaver Ditch diversion, near Beckton, Wyo. } \\
\hline $8-5-77$ & 83.1 & $\begin{array}{l}\text { Ragsdale, Pedersen, Englert, } \\
\text { Moore }\end{array}$ & $\begin{array}{l}\text { Mixing good; plateau definition erratic. } \\
\text { Current-meter measurement }=64.7 \mathrm{ft}^{3} / \mathrm{s} \text {. }\end{array}$ \\
\hline \multicolumn{4}{|c|}{ Site 7-06309200 Middle Fork Powder River near Barnum, Wyo. } \\
\hline $6-6-75$ & 674 & Glass & $\begin{array}{l}\text { Injection rate constant before sampling; not measured after } \\
\text { sampling. Mixing not verified (all samples taken within nearest } \\
\text { one-third of channel width). }\end{array}$ \\
\hline $5-18-76$ & 256 & Glass, Pedersen & Rising stage. Mixing good. \\
\hline 4-30-77 & 631 & Glass & $\begin{array}{l}\text { Mixing not verified past midstream. Measurement not used for } \\
\text { stage-discharge relation. }\end{array}$ \\
\hline $5-23-77$ & 140 & Glass & Mixing excellent. Current-meter measurement $=134 \mathrm{ft}^{3} / \mathrm{s}$. \\
\hline $5-24-78$ & 800 & Glass & $\begin{array}{l}\text { Poor measurement, mainly due to erratic and declining injection rate } \\
\text { during sampling. Mixing very good. }\end{array}$ \\
\hline \multicolumn{4}{|c|}{ Site 8-06646600 Deer Creek below Millar wasteway, at Glenrock, Wyo. } \\
\hline $5-8-75$ & 173 & $\begin{array}{l}\text { Casper and Worland field } \\
\text { personnel }\end{array}$ & $\begin{array}{l}\text { Training measurement. Poor lateral mixing. Current-meter } \\
\text { measurement }=182 \mathrm{ft}^{3} / \mathrm{s} \text {. }\end{array}$ \\
\hline $5-10-77$ & 251 & $\begin{array}{l}\text { Casper and Cheyenne field } \\
\text { personnel }\end{array}$ & $\begin{array}{l}\text { Training measurement. Good lateral mixing. Current-meter } \\
\text { measurement }=239 \mathrm{ft}^{3} / \mathrm{s} \text {. }\end{array}$ \\
\hline
\end{tabular}




\section{INVESTIGATIONS IN KARST TERRANE}

\section{Methods}

The availability of water in carbonate rocks and the relation of streamflow across outcrop areas to water in the underlying carbonate aquifers in Wyoming have been the subject of several hydrologic investigations. Losing or gaining streams, sink holes, caves, and sinking streams (streams that disappear into caves) are typical features that define the surface and subsurface topography called karst terrane. Karst features develop as a result of dissolution of carbonate rocks-mainly limestone and dolomite-as ground water passes through fractures in the rocks. Most exposed karst features in Wyoming are in moderately to steeply dipping carbonate rocks on the flanks of major mountain ranges and other uplifts (Hill and others, 1976, p. 12, fig. 1). Additional information on karst processes and features is given by Hill and others (1976, p. 11-18) and Mull and others (1988, p. 6-20).

Dye tests can provide information that water managers can use to understand streamflow losses or gains as to destination or source when allocating the affected water resources. Dye tests have been made in four losing streams in northeastern Wyoming: North Fork Powder River, North Fork Crazy Woman Creek, Little Tongue River, and Smith Creek; and in a sinking stream in west-central Wyoming: Middle Popo Agie River. The tests of the Little Tongue and Middle Popo Agie Rivers also involved caves. Each of the five dye tests is described in a subsequent unit. The stratigraphic position of the formations of Paleozoic age mentioned in these units is shown in figure 35.

Procedures. - Path tracing in caves may be the oldest application of dye tracing. Dye is injected at known or suspected inflow points and detected visually or with an ultraviolet ("black") light at known or suspected resurgence points. The configuration and dimensions of the intervening conduits usually are unknown. Mull and others (1988, p. 22) refer to this technique as qualitative tracing. Fluorescein, a fluorescent yellow-green dye, commonly is used.

Rhodamine WT, a fluorescent red dye accurately detectable in sub-visible concentrations with a modern fluorometer, is the dye of choice for most quantitative tracing. Rhodamine WT was used in all Wyoming dye tests, most of which had primary qualitative objectives and secondary quantitative objectives.
For each test in Wyoming, dye was injected into the stream, and samples were collected at springs or other points of resurgence, usually throughout the entire passage of the dye. The samples were tested in a fluorometer. For some of the tests, dye recovery was calculated as described below. More complicated hydrologic systems require more elaborate procedures, as described in a manual prepared by the USGS in Kentucky (Mull and others, 1988).

Dye-Recovery Calculation.-The term "dye recovery" is used to indicate the amount of dye accounted for by sampling. Dye recovery is calculated for tests in karst terrane to evaluate how much water entering the system at the injection site emerges at the sampled site(s) of resurgence. The tendency of the dye to adhere to the rocks, sand, and gravel through which the water passes, however, may affect the amount accounted for at the sampling sites. In karst terrane, there usually is no way to determine how much of the dye unaccounted for is lost to sorption and how much is lost to underground storage or diversion.

Dye recovery is calculated either by using dye concentrations determined from direct calibration of the fluorometer, or indirectly using concentrations expressed in fluorometer units. For the indirect method of calibration, the amount of dye recovered is calculated using the following equation, modified from Kilpatrick (1993, p. 4, eq. 2):

$$
\boldsymbol{R}=28,320 \times \frac{Q A}{F},
$$

where $\boldsymbol{R}$ is the amount of rhodamine WT dye solution (20 percent strength) recovered, in milliliters, $\boldsymbol{Q}$ is stream discharge, in cubic feet per second,

$\boldsymbol{A}$ is the area under the dye-response curve, in fluorometer units times seconds,

$\boldsymbol{F}$ is the fluorescence of a precisely diluted sample of the injection solution, in fluorometer units multiplied by the amount of dilution (ratio of dye to water plus dye), and

28,320 is milliliters per cubic foot.

Percent recovery is the amount of dye accounted for by sampling divided by the amount of dye injected, multiplied by 100 . 


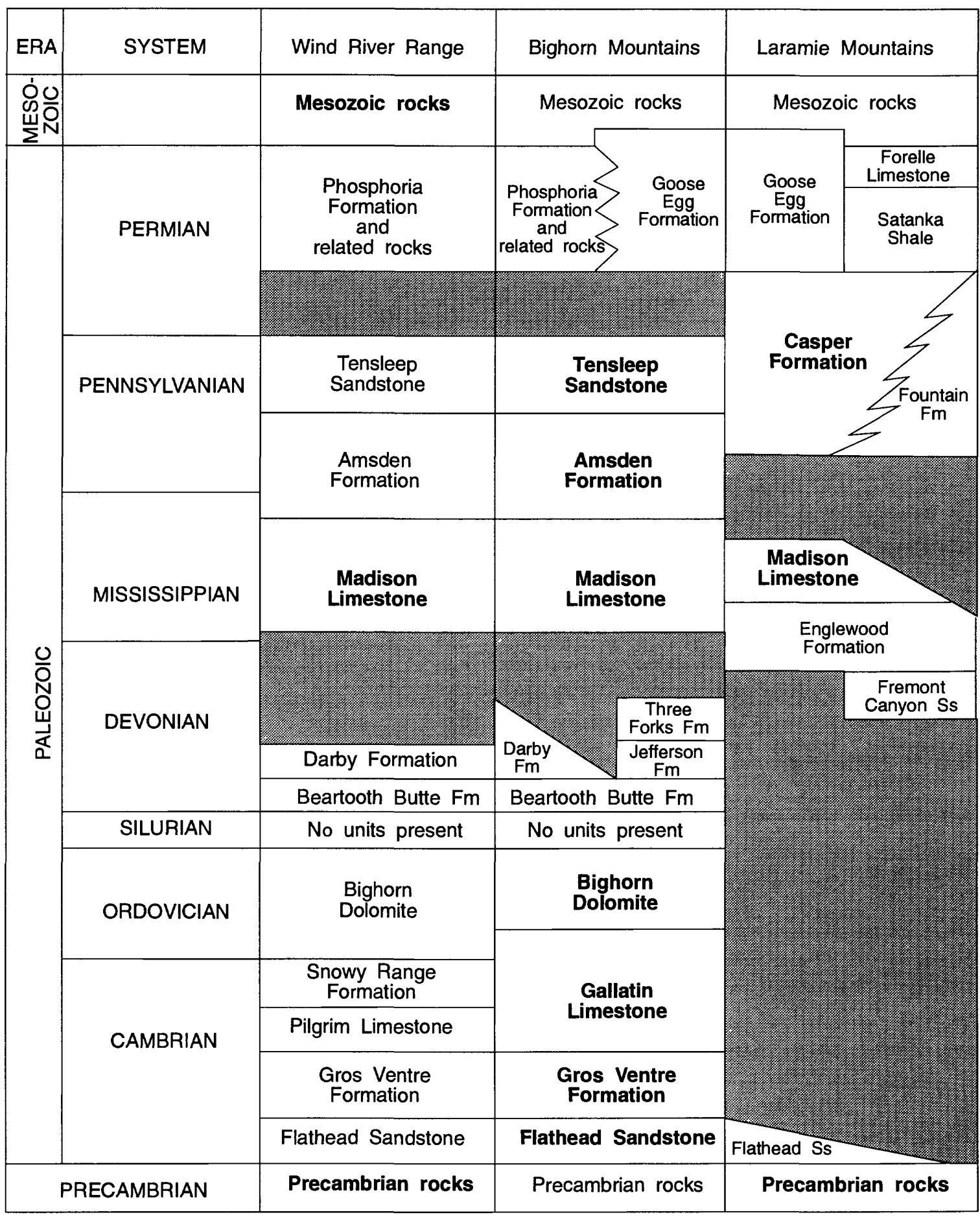

\section{EXPLANATION}

HIATUS-Some minor formations not shown

Abbreviations: Fm, Formation; Ss, Sandstone

Figure 35. Generalized stratigraphic chart of formations of Paleozoic age in parts of Wyoming where dye tests were conducted in karst terrane (modified from Love and others, 1993). Names in bold letters are mentioned in text. 


\title{
INVESTIGATIONS IN KARST TERRANE-Continued
}

\author{
North Fork Powder River below Dullknife Reservoir, 1970
}

[Investigation in cooperation with the Wyoming State Engineer]

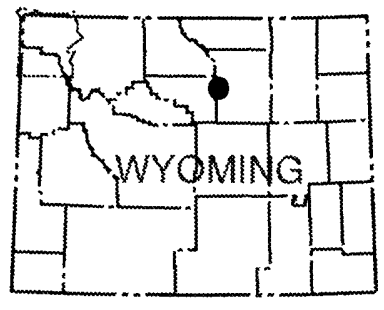

Downstream from Dullknife Reservoir the North Fork Powder River flows across sinkholes near the mouth of Bull Creek and across another losing reach upstream from the mouth of Johnson Creek (fig. 36). Water discharges from a large spring downstream from Johnson Creek. A dye test was conducted during 1970 to assist the Wyoming State Engineer in evaluating loss of water released from the reservoir for irrigation. Supplementary geologic information was obtained during 1971.

Study Reach.-On September 16, 1971 Warren G. Hodson and Marlin E. Lowry, USGS, accompanied by Paul Kawulok, State Engineer's Office, examined the geology along the 3.7-mile reach between the sinkholes near Bull Creek and the spring, which is about 0.7 mile downstream from Johnson Creek (fig. 36). Their observations are described in Boner and others (1976, p. 30-31). The sinkholes are about 2.1 miles downstream from the reservoir. For some distance downstream from Bull Creek, the North Fork Powder River flows along an extensive fault zone, where the Tensleep Sandstone of Pennsylvanian age is adjacent to the Flathead Sandstone of Cambrian age. Displacement is as much as 1,400 feet. Several hundred feet of carbonate rocks underlie the Tensleep.

At the time of the geologic reconnaissance, some one had placed straw over the sinkholes near Bull Creek, partly plugging them. Flow passing the sinkholes was about $20 \mathrm{ft}^{3} / \mathrm{s}$. For the next 2.1 miles, the stream flows across the Tensleep Sandstone or the Amsden Formation of Pennsylvanian and Mississippian age, with no apparent changes in flow. Over the next 0.6 mile, however, where the stream flows over the Madison Limestone of Mississippian age, the entire flow disappeared below the stream bed. Flow in the channel resumed at the large spring below Johnson Creek.

Dye Test.-The test was made November 4-6, 1970 by Hugh W. Lowham, USGS, assisted by Paul Kawulok, to assess the hydraulic connection between the sinkholes near Bull Creek and the spring below Johnson Creek. Prior to the test, no water was being released from the dam, but seepage was about $0.5 \mathrm{ft}^{3} / \mathrm{s}$. Stream discharge was about $1.5 \mathrm{ft}^{3} / \mathrm{s}$ just upstream from the sinkholes, about $5 \mathrm{ft}^{3} / \mathrm{s}$ at the spring, and $20 \mathrm{ft}^{3} / \mathrm{s}$ at the streamflow-gaging station about 16 miles downstream from the dam (station 06311500, North Fork Powder River near Mayoworth, Wyo.). On November 4 Kawulok opened the reservoir outlet to release a constant flow of $22 \mathrm{ft}^{3} / \mathrm{s}$ for the next 49 hours. The leading edge of the released water reached the sinkhole area near Bull Creek in about 2 hours.

After the flow at the sinkholes had stabilized, the investigators poured 2 liters of rhodamine WT dye into the river just upstream from the sinkholes. The stream discharge was measured as $23.4 \mathrm{ft}^{3} / \mathrm{s}$ upstream from the sinkholes and $3.29 \mathrm{ft}^{3} / \mathrm{s}$ downstream. Thus, about $20.1 \mathrm{ft}^{3} / \mathrm{s}$ was entering the sinkholes (fig. 37).

Water samples were collected at the large spring below Johnson Creek, about 3.7 miles downstream from the dye-injection site. The dye-response curve (fig. 38) indicates that at least some water entering the sinkholes discharges from the spring. However, only about 6 percent of the dye injected was accounted for by sampling.

Although flow from the reservoir was steady throughout the dye test, discharge from the spring first increased to about $16 \mathrm{ft}^{3} / \mathrm{s}$, then rapidly decreased (fig. 37), indicating a possible underground siphon. Also, roughly 60 percent of the volume of water that entered the sinkholes during the dye test was not accounted for at the gaging station. Additional dye tests might help determine: (1) why the flow from the spring decreased during steady release from the reservoir, (2) the connection of the second losing reach to the spring, and (3) the fate of water lost in the streambed but not accounted for at the gaging station. 

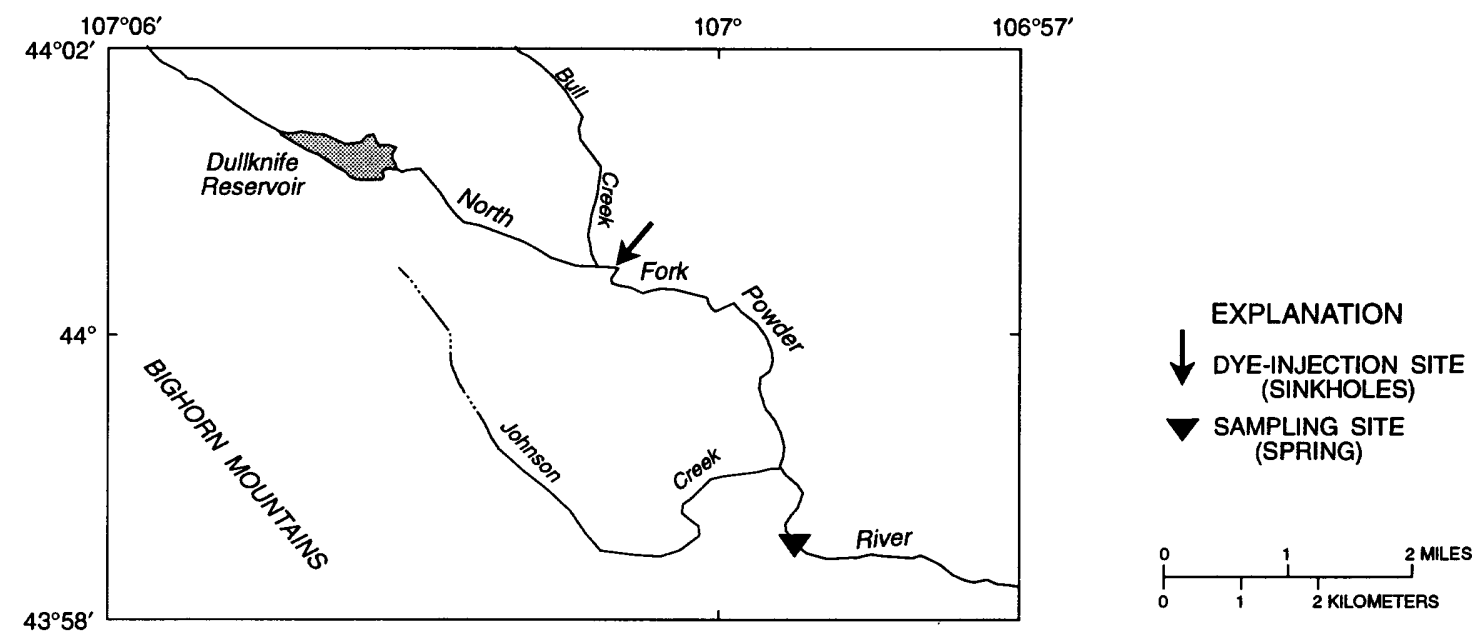

Figure 36. Location of dye-injection and sampling sites, North Fork Powder River. Study reach is approximately 28 miles southwest of Buffalo, Wyoming.

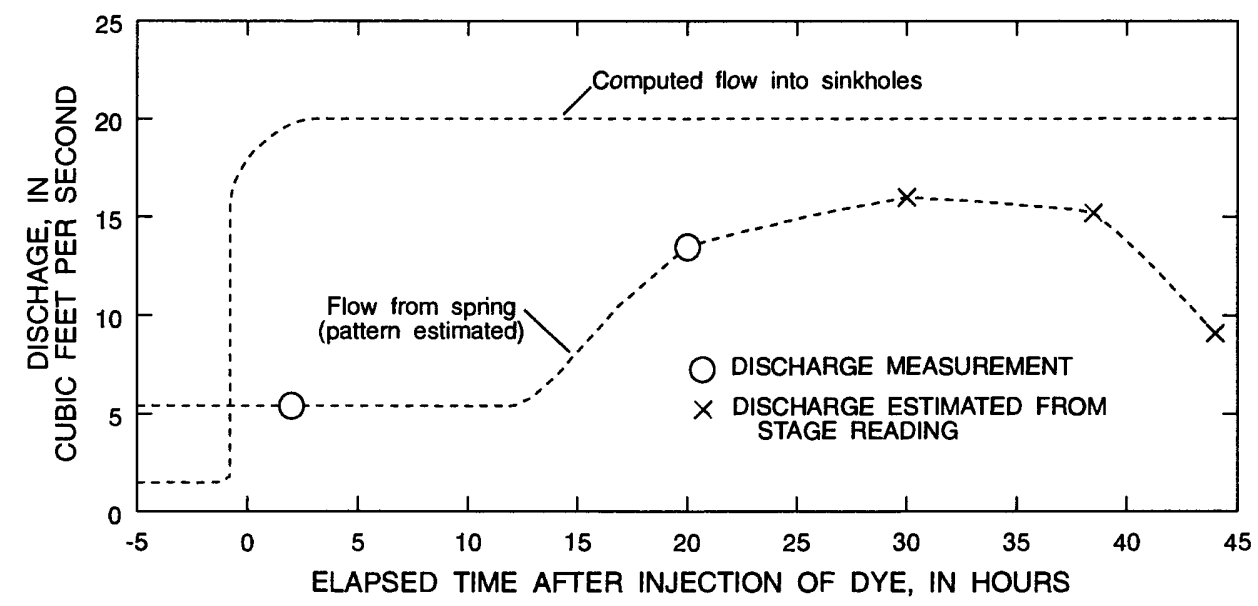

Figure 37. Hydrographs of flow into sinkholes near Bull Creek and flow from large spring below Johnson Creek, North Fork Powder River downstream from Dullknife Reservoir, November 4-6, 1970.

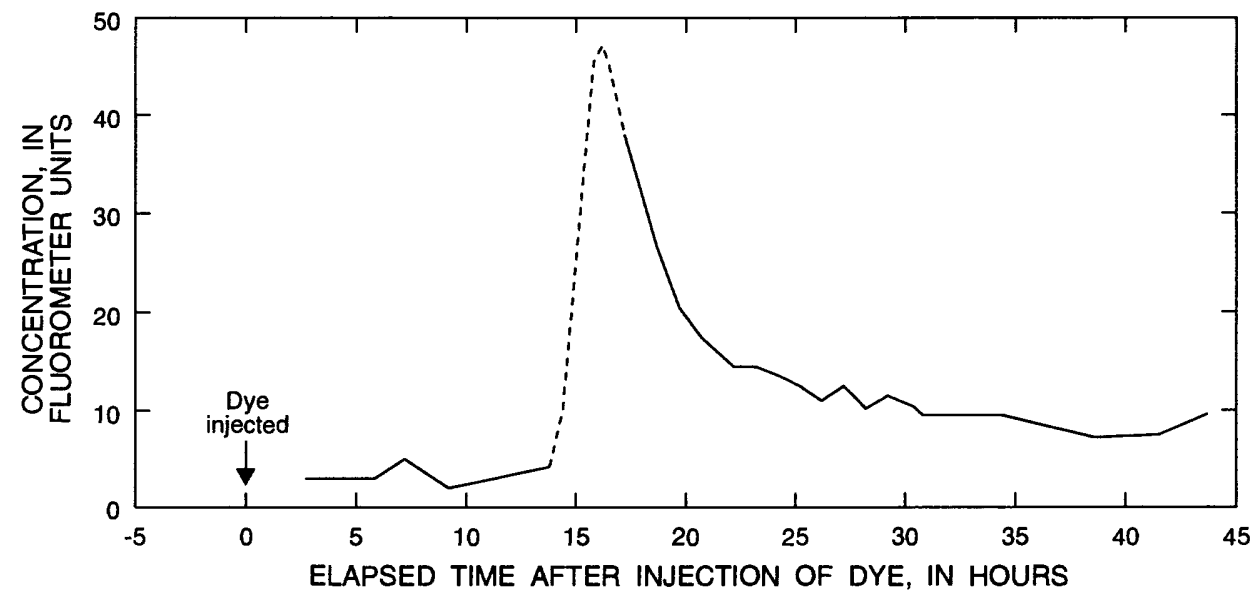

Figure 38. Dye-response curve in North Fork Powder River at large spring downstream from Dullknife Reservoir, November 4-6, 1970. Curve is dashed where estimated (no samples). 


\title{
INVESTIGATIONS IN KARST TERRANE-Continued
}

\author{
North Fork Crazy Woman Creek, 1974
}

\section{[Investigation in cooperation with the Wyoming State Engineer and the Old West Regional Commission]}

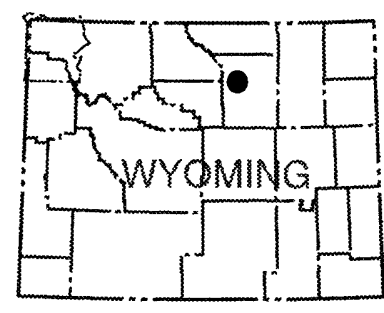

During the summer of 1974 a geohydrologic field reconnaissance was made of 55 perennial streams where they cross rocks of Paleozoic age-particularly the Madison Limestone of Mississippian age-in northeastern Wyoming (Boner and others, 1976). Subsequently, 32 streamflow-gaging stations were installed at selected sites to determine streamflow loss or gain in the reaches across the outcrops of the Madison. The objective was to provide data for estimating recharge to the Madison Limestone, a potential major source of water for the rapidly increasing development of the vast coal deposits in northeastern Wyoming. As a part of the reconnaissance, dye tests were made in two losing streams with known or suspected sites of resurgence: North Fork Crazy Woman Creek (fig. 39) and Little Tongue River (discussed in the next unit).

Study Reach.-A geologic traverse of the study reach (site 16 to site 17 , fig. 39 ) is described by Boner and others (1976, p. 27). In that reach, North Fork Crazy Woman Creek flows eastward across successively younger Paleozoic rocks. The upstream end of the reach is in rocks of Cambrian age, near the base of the Bighorn Dolomite of Ordovician age. The downstream end is near the top of the Tensleep Sandstone of Pennsylvanian age. In the 1.3-mile reach, the stream also crosses the Madison Limestone.

Between the two sites (fig. 39) three zones of streamflow loss were particularly noticeable during low flow. The two primary zones were about 0.7 mile and 0.9 mile downstream from the upper measuring site. Loss of about equal amounts at these sites nearly depleted the flow. A small amount remained, but was lost a few hundred feet farther downstream. Flow resumed a short distance upstream from the lower site, issuing from springs near the top of the Madison Limestone.

Streamflow-gaging stations were operated at both sites during 1974-84. The records were analyzed by Glass and Sultz (1992, p. 49-53) for monthly and annual gains and losses. Annual net losses were recorded during 7 years, and net gains during 4 years. The annual differences typically were 2 to 4 percent of the flow at the upper site.

Dye Test.-On September 25, 1974 Hugh W. Lowham and Marlin E. Lowry, USGS, Cheyenne, Wyo., injected a measured quantity of rhodamine WT dye as a single slug into the stream at the site of the upstream station (site 16, fig. 39). A brief description of the test is given in Boner and others (1976, p. 27).

Samples were collected at the site of the downstream station (site 17, fig. 39), approximately 1.3 miles from the injection site. The dye arrived as three separate peaks. The first peak arrived in the small streamflow that bypasses the two major zones of loss 3.50 hours after injection. The other peaks arrived 6.75 and 9.50 hours after injection, indicating multiple underground conduits. The relation of these two peaks to other sinks and springs was not observed.

Sampling accounted for about 73 percent of the dye injected. Sorptive loss might account for some or all of the remaining 27 percent. In addition to sorptive loss, however, part of the water passing the upstream site may have discharged elsewhere. In any case, ground water from another source had entered the stream between the two measuring sites. Discharge measured at the downstream site was $9.81 \mathrm{ft}^{3} / \mathrm{s}$, about 9 percent greater than the discharge measured at the upstream site, $8.98 \mathrm{ft}^{3} / \mathrm{s}$ (Glass and Sultz, 1992, p. 49). 

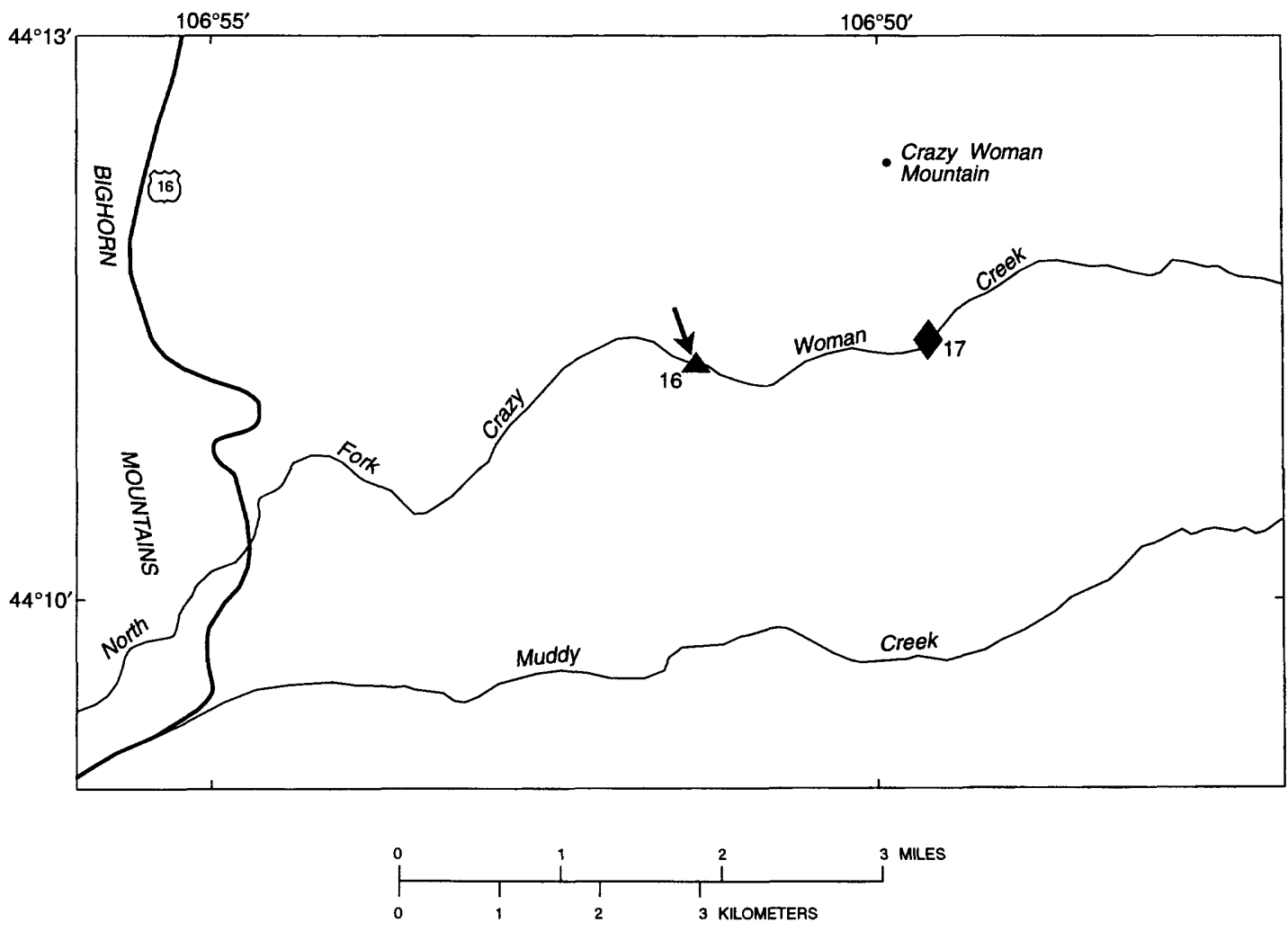

EXPLANATION

16. STREAMFLOW-GAGING STATION

AND SITE NUMBER

$\downarrow$ DYE-INJECTION SITE

SAMPLING SITE

Figure 39. Location of streamflow-gaging stations and dye-injection and sampling sites, North Fork Crazy Woman Creek. Study reach is approximately 13 miles southwest of Buffalo, Wyoming (see map on p. 31). Site numbers are from Glass and Sultz (1992). 


\title{
INVESTIGATIONS IN KARST TERRANE-Continued
}

\author{
Little Tongue River and Tongue River Cave, 1974
}

\section{[Investigation in cooperation with the Wyoming State Engineer and the Old West Regional Commission]}

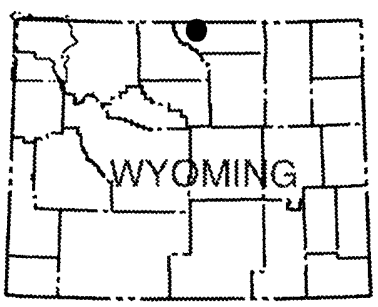

The 1974 geohydrologic reconnaissance of streams flowing across rocks of Paleozoic age in northeastern Wyoming (Boner and others, 1976), described in the preceding unit, included the Tongue and Little Tongue Rivers (fig. 40). The main objective of the investigation was to provide data for estimating recharge to the Madison Limestone of Mississippian age. A dye test was made in the Little Tongue River, a losing stream. Some of the water lost from the Little Tongue is known to resurge in Tongue River Cave, and subsequently, the Tongue River.

Study Reach.-The upstream site on the Little Tongue River (site 5, fig. 40) is along the strike of the Gallatin Limestone of Cambrian and Ordovician age and the Gros Ventre Formation of Cambrian age, and near the base of the Bighorn Dolomite of Ordovician age (Boner and others, 1976, p. 20). All of the flow is lost beneath the stream bed within about 300 feet downstream from site 5. Annual flow at the downstream site (site 6 , fig. 40 ) was 8.9 percent less than at the upstream site in 1975 and 18.6 percent less during 1976 (Glass and Sultz, 1992, p. 28-30). How much, if any, of the water at the upstream site reaches the downstream site is not known.

Lowry and Cummings (1966, p. 29) made a qualitative dye test in about 1960 using fluorescein dye and visual detection. That test confirmed that at least part of the water lost from the Little Tongue River undergoes subterranean diversion northward to Tongue River Cave in the Bighorn Dolomite. Some of the dyetagged water appeared in the underground stream called Cave Creek, which flows through the rear part of the cave (see Hill and others, 1976, p. 123-125 and map sheet 3 ). The cave entrance is near the Tongue River (fig. 40), approximately 2.6 miles north of the losing reach of the Little Tongue River and 2,500 feet lower in elevation. The stream enters the cave approximately 1,600 feet south-southeast of the cave entrance and exits the mapped part of the cave approximately 1,300 feet north of where it enters. It discharges into the Tongue River (Lowry and Cummings, 1966, p. 29).

Dye Test.-A quantitative dye test was made for the recharge study, to determine how much of the water lost in the stream channel reappears in the cave. On October 29, 1974 at 4:30 p.m., 389 mL of rhodamine WT dye was injected into the Little Tongue River about 300 feet downstream from the upper measurement site (site 5, fig. 40) and 200 feet upstream from where water was last visible on the stream bed. Estimated discharge was $2 \mathrm{ft}^{3} / \mathrm{s}$ at the upper measurement site and $0.5 \mathrm{ft}^{3} / \mathrm{s}$ at the dye-injection site. Sampling of Cave Creek commenced at 7:50 p.m., October 30, 1974, and continued for about 3 days. The water samples were tested in a fluorometer onsite to guide sampling and were retested later under laboratory conditions. A single peak concentration arrived 34 hours after injection (fig. 41), indicating the dye probably followed a single underground conduit to the sampling site. The stream was not sampled at site 6 (fig. 40).

The average of three measurements of discharge in Cave Creek, $1.76 \mathrm{ft}^{3} / \mathrm{s}$, was used to calculate dye recovery. Only 35 percent of the dye injected into the river was accounted for by sampling. Therefore, only part of the water lost from the Little Tongue River reaches Cave Creek.

The part of the water lost in the channel of the Little Tongue River that passes through the cave and resurges in the Tongue River does not represent recharge to the Madison Limestone. When reporting on the dye test, D.T. Hoxie (U.S. Geological Survey, written commun., 1974) stated: "The possibility that [subterranean diversion between surface drainages] occurs elsewhere in the [Bighorn Mountains] must be taken into account in any analysis of recharge to the carbonate aquifers using streamflow data $* * *$." 


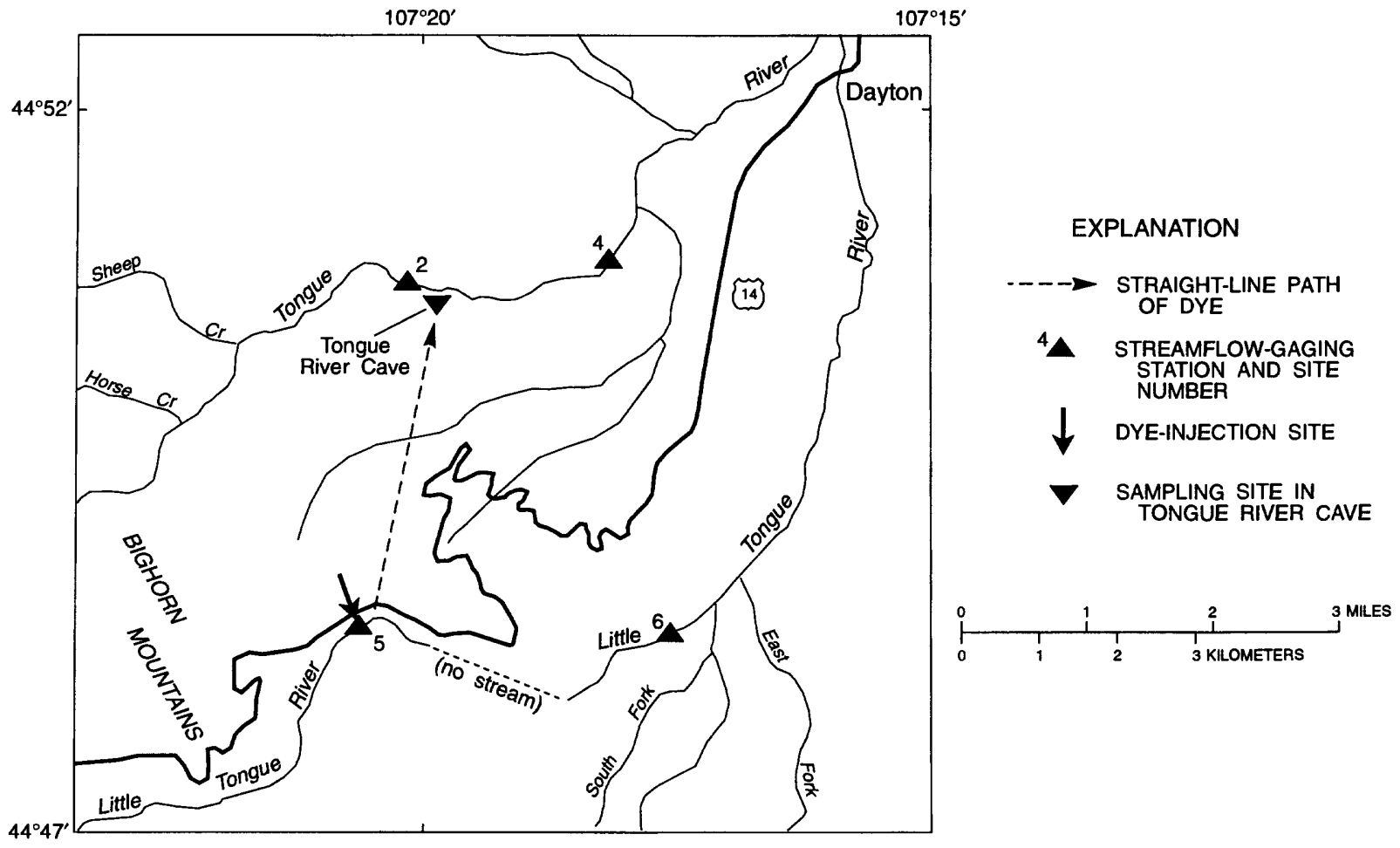

Figure 40. Location of streamflow-gaging stations, dye-injection site in the Little Tongue River, and dye-sampling site in Tongue River Cave. Site 5 is about 19 miles west of Sheridan, Wyoming. Site numbers are from Glass and Sultz (1992).

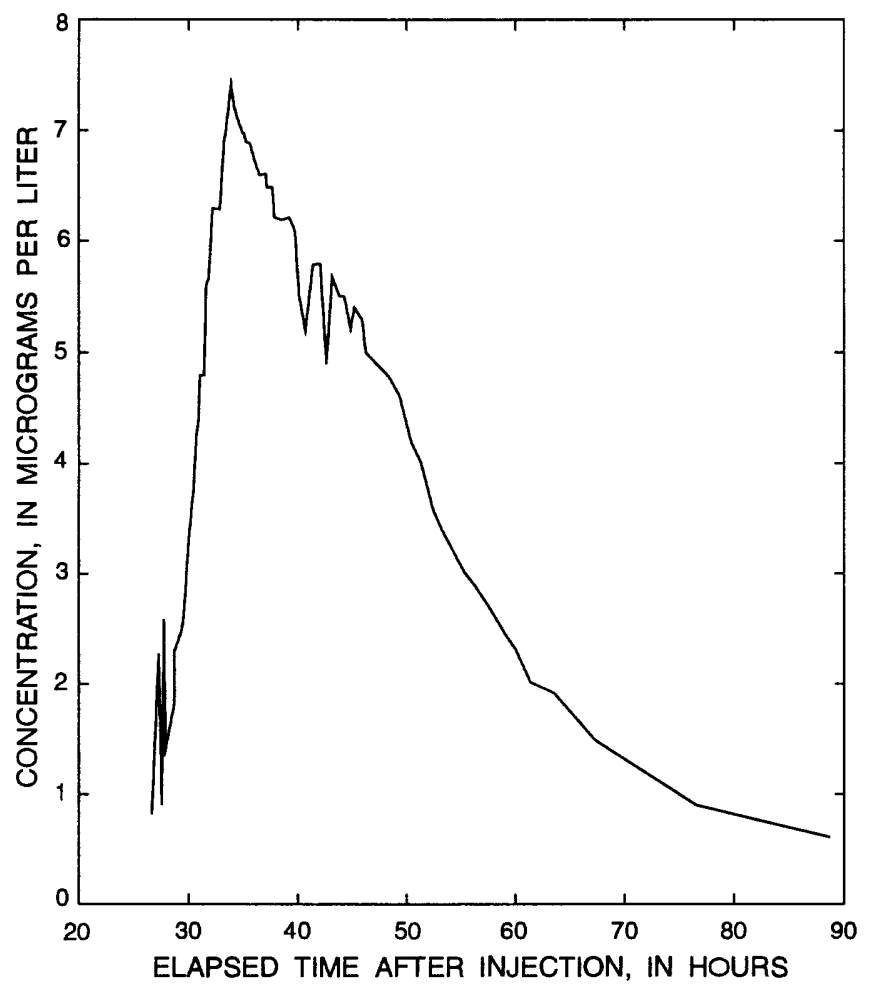

Figure 41. Dye-response curve in Cave Creek in Tongue River Cave, October 30-November 2, 1974 (modified from D.T. Hoxie, U.S. Geological Survey, written commun., 1974). Graph not previously published. 


\section{INVESTIGATIONS IN KARST TERRANE-Continued

\author{
Physical Setting
} \\ Middle Popo Agie River in Sinks Canyon State Park, 1983}

[Investigation in cooperation with the Wyoming Recreation Commission ${ }^{1}$ ]

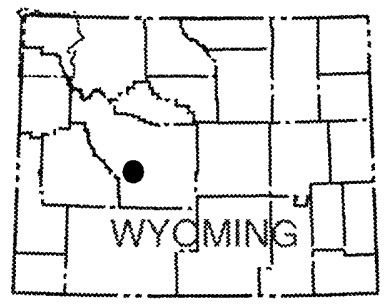

In 1983 the USGS assisted the Wyoming Recreation Commission ${ }^{1}$ in conducting a dye test of the Middle Popo Agie River in Sinks Canyon State Park. The river disappears into Sinks of Lander Cave ("the Sinks"), and surface flow resumes at "the Rise," about 0.6 mile northeast of the Sinks (fig. 42). The intervening surface channel is dry, except during large floods when some flow bypasses the cave entrance. Prior to 1983 the hydraulic connection of the Rise to the Sinks had not been proven. Hill and others (1976, p. 129) state: "there has been speculation that the rise $* * *$ is not the resurgence of this cave's waters. $* * *$ Although not yet dye tested, the sink and rise appear to have a normal karst relationship."

The primary objective of the 1983 dye test was to verify the connection of the Rise to the Sinks. A few years earlier, Orren Bower, then Lander City Engineer, had tried unsuccessfully to verify the connection using fluorescein dye and a black light (Tom King, Wyoming State Engineer's Office, oral commun., 1983).

The River and the Cave.-Flow in the Middle Popo Agie River is sustained by the melting of highmountain snowpack and by ground-water discharge. The river begins in an area of igneous and metamorphic rocks of Precambrian age, then flows northeastward across a sequence of rocks of Paleozoic age to the Sinks, where it turns sharply southward to enter the cave. The rocks dip approximately 15 degrees to the

\footnotetext{
${ }^{1}$ Sinks Canyon State Park now (1996) is administered by the Division of State Parks \& Historic Sites, Wyoming Department of Commerce.
}

northeast (Roberts, 1987, p. 62), the same general direction in which the river flows. Downstream from the Rise, the river flows across rocks of Mesozoic age.

Sinks of Lander Cave is a dissolution feature in the Madison Limestone of Mississippian age (Hill and others, 1976, p. 129). At the farthest point mapped (about 200 feet from the entrance) the water moves in the opposite direction to that of the surface channel. The distance between that point and the Rise is about 3,500 feet. About 90 feet of the 210 -foot difference in surface elevation between the Sinks and the Rise occurs within the mapped part of the cave (Hill and others, 1976, p. 129 and map sheet 2).

The Rise is a large pool in what may be a dissolution-collapse feature (J.S. McLean, U.S. Geological Survey, oral commun., 1984). Springs flow upward through the sand-and-gravel bed of the pool. Springs and seeps flow from the limestone headwalls at the Rise and from the canyon walls for some distance downstream. Records for the streamflowgaging station about 0.5 mile downstream (fig. 42) indicate that the flow is sustained by ground-water discharge throughout the year (fig. 43).

Acknowledgments.-Gary Stephenson, Wyoming Recreation Commission, initiated the study and made the necessary arrangements. Ronald Livesay, Superintendent of Sinks Canyon State Park, was instrumental in planning the test. Ronald Fuller, Park Attendant, coordinated the field work. Park Naturalist Donald Higgins assisted in the field work and contributed to the assessment of the hydrologic system. Park Attendant Jennifer Crook and Recreation Commission photographer Kerry Kelley assisted in the collection of water samples. Philip McCollam, USGS, measured the stream discharge and assisted in sample collection. The staff of station KCWC-TV, Riverton, Wyo., produced an excellent video of the field work. Park personnel developed exhibits and a folder (Wyoming Department of Commerce, 1993) describing the dye test. 


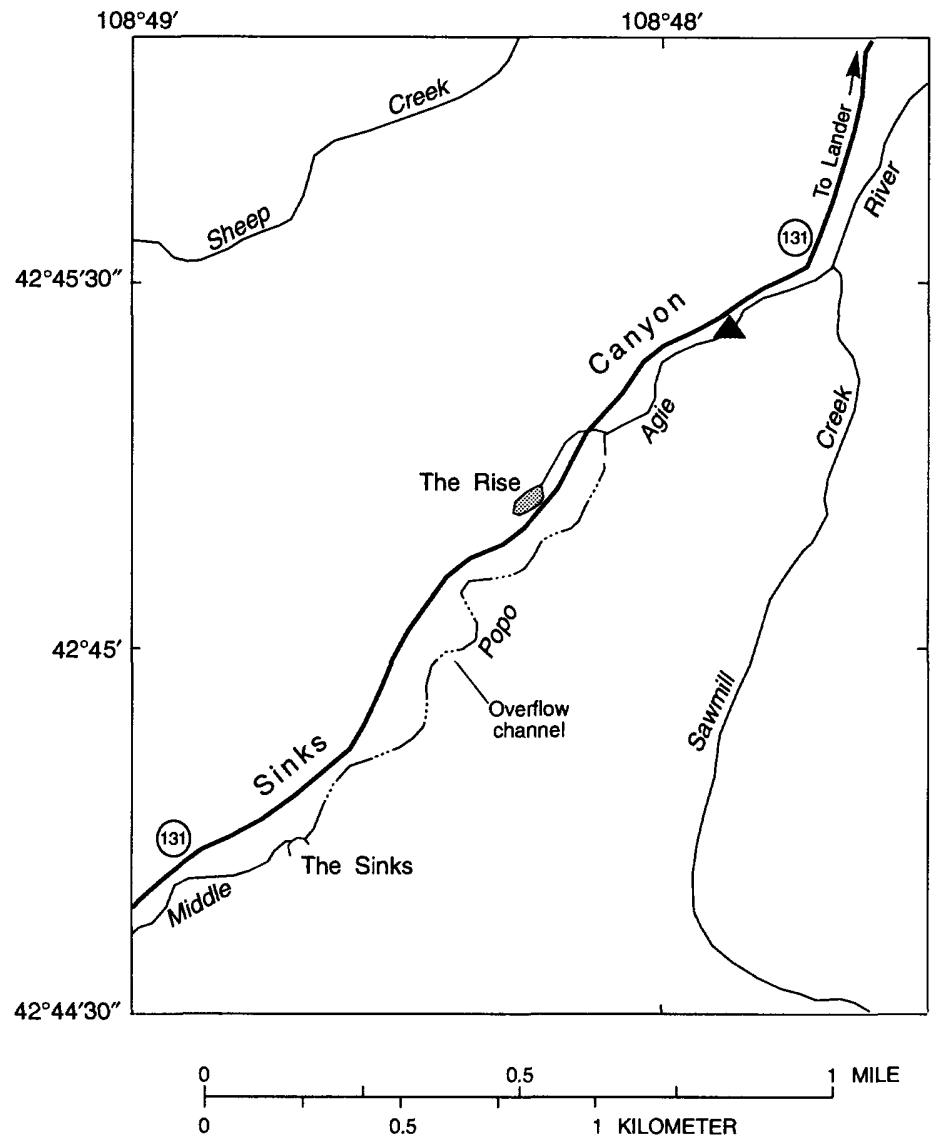

EXPLANATION

A STREAMFLOW-GAGING STATION 06231600

Figure 42. Location of the Sinks and the Rise, Sinks Canyon State Park. Study reach is approximately 7 miles southwest of Lander, Wyoming.

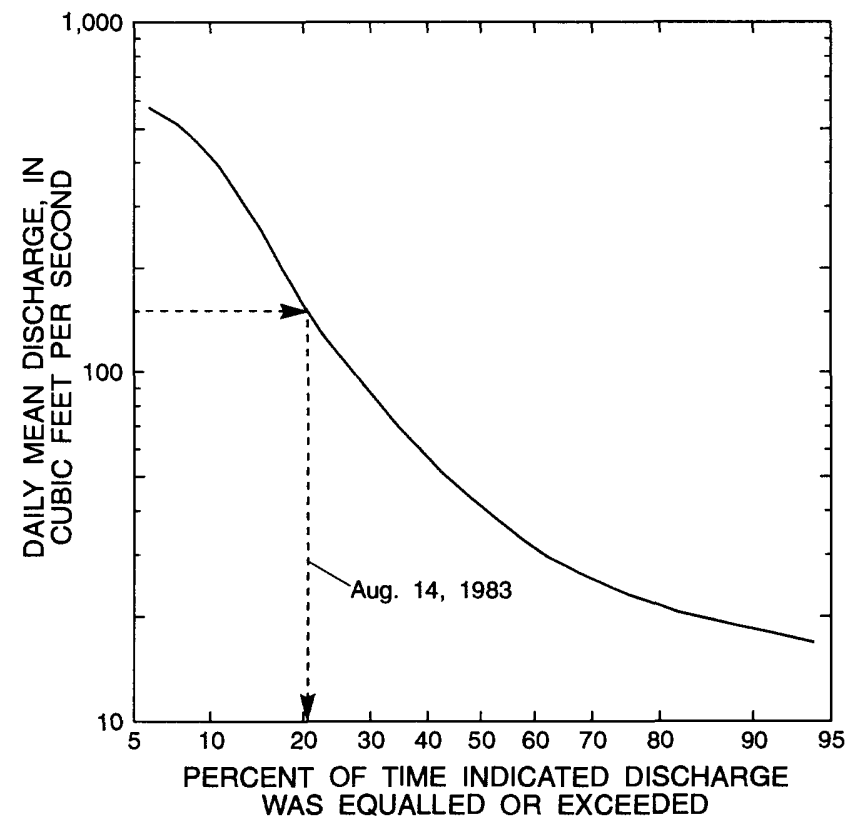

Figure 43. Flow-duration curve for streamflow-gaging station 06231600, Middle Popo Agie River below the Sinks, near Lander, Wyoming, water years 1960-68. 


\section{INVESTIGATIONS IN KARST TERRANE-Continued}

\section{Middle Popo Agie River in Sinks Canyon State Park, 1983-Continued

\author{
Data Collection
}

Dye Injection and Sampling.-At 1:00 p.m. on August 14, 1983 a mixture of $40 \mathrm{~mL}$ of rhodamine WT dye and approximately 2 gallons of water from the stream was injected into the river approximately 200 feet upstream from the mouth of the cave (figs. 42 and 44). The amount of dye was estimated by the method for surface streams (Kilpatrick and Wilson, 1989, p. 14-15). A small sample of the injection solution was retained for indirect calibration of the fluorometer later.

Water samples for fluorometric analysis were collected at three points in the large pool at the Rise (figs. 42 and 45) starting at about 1:10 p.m. on August 14, 1983: (1) At a visible spring within the pool at the right side, beneath the overlook platform near the head of the pool (site A, fig. 45); (2) a few feet from the right bank at the old power plant (site B); and (3) at a sand bar at the left bank near the downstream end of the pool (site C).

The presence or absence of dye in the water samples was determined onsite by testing the water in a fluorometer. A 5-minute sampling interval was maintained until the peak concentration of dye had passed, after which the interval was increased periodically. By 6:30 p.m. the concentration of dye had decreased almost to the detection limit. Two samples collected the following morning (August 15) contained no detectable dye. All samples containing dye and a few background samples collected before the dye arrived were retained in glass bottles. The samples were retested later at the USGS laboratory in Cheyenne.

Stream Discharge.- On the day of the dye test, the change in discharge between the cave and the Rise was determined. The discharge at a small diversion dam approximately 0.25 mile upstream from the mouth of the cave was $80.8 \mathrm{ft}^{3} / \mathrm{s}$, as measured with a current meter. The discharge at the streamflow-gaging station 0.5 mile downstream from the Rise was determined from the station rating curve to be $136 \mathrm{ft}^{3} / \mathrm{s}$, somewhat larger than the average daily discharge during 1959-68 $\left(123 \mathrm{ft}^{3} / \mathrm{s}\right)$. During the period of record, daily mean discharge at the station exceeded $136 \mathrm{ft}^{3} / \mathrm{s}$ about 20 percent of the time (fig. 43 , p. 45). Discharge at the outlet of the pool at the Rise is assumed to be approximately the same as the discharge at the station.

The two values of discharge indicate a net gain of approximately $55 \mathrm{ft}^{3} / \mathrm{s}$ between the Sinks and the gaging station on the day of the dye test. The gain is unlikely to have been caused by variation in discharge entering the cave; the recorder trace at the station indicated that the discharge had been nearly constant for several days.

Water Temperature.-Water temperatures were measured at several places in the study reach on the day of the dye test (table 9). The increase of about $8^{\circ} \mathrm{C}$ (about $14^{\circ} \mathrm{F}$ (degrees Fahrenheit)) between the Sinks and the Rise indicates the possibility that some geothermal water is being discharged to the stream. A simple mass-balance calculation indicates that the temperature of the additional water would be about $26^{\circ} \mathrm{C}\left(79^{\circ} \mathrm{F}\right)$.

Table 9. Water temperatures in the Middle Popo Agie River at the Sinks and the Rise and in a spring near the Rise, Sinks Canyon State Park, Wyoming, August 14, 1983

\begin{tabular}{lcc}
\hline \multicolumn{1}{c}{ Location } & $\begin{array}{c}\text { Temper- } \\
\text { Time } \\
\text { (p.m.) }\end{array}$ & $\begin{array}{c}\text { (degrees } \\
\text { Celsius) }\end{array}$ \\
\hline Middle Popo Agie River at Sinks & $1: 00$ & 6.5 \\
Spring in left headwall at Rise & $1: 10$ & 14.0 \\
Spring in pool (right side) at Rise & $1: 10$ & 14.5 \\
& $3: 55$ & 15.0 \\
Flowing water in pool (right side) at & $1: 10$ & 14.0 \\
$\quad$ Rise & $3: 55$ & 15.0 \\
\hline
\end{tabular}




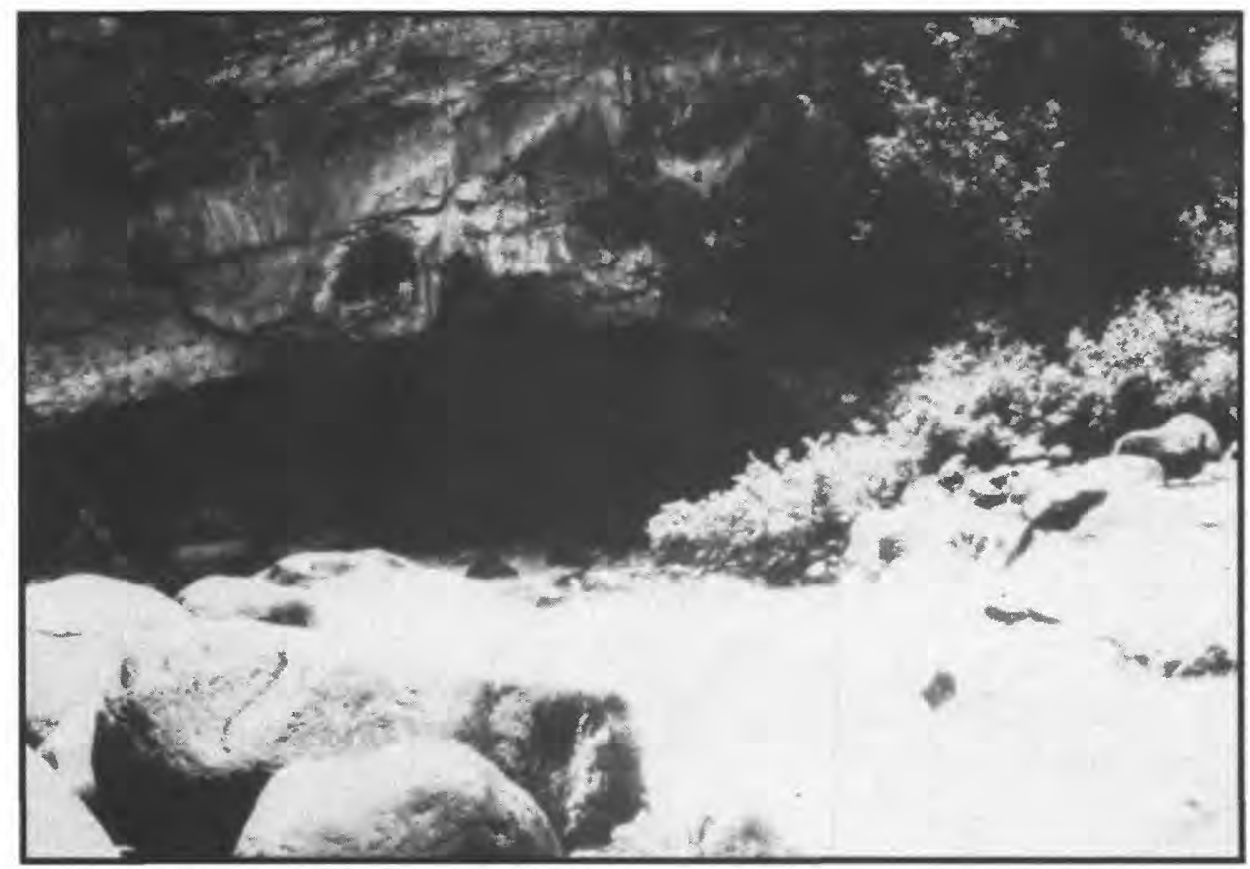

Figure 44. The Sinks, Sinks Canyon State Park, August 14, 1983. Flow is from right to left. Dye was injected about 100 feet upstream from point of photograph. Photograph by Kerry Kelley, Wyoming Recreation Commission.

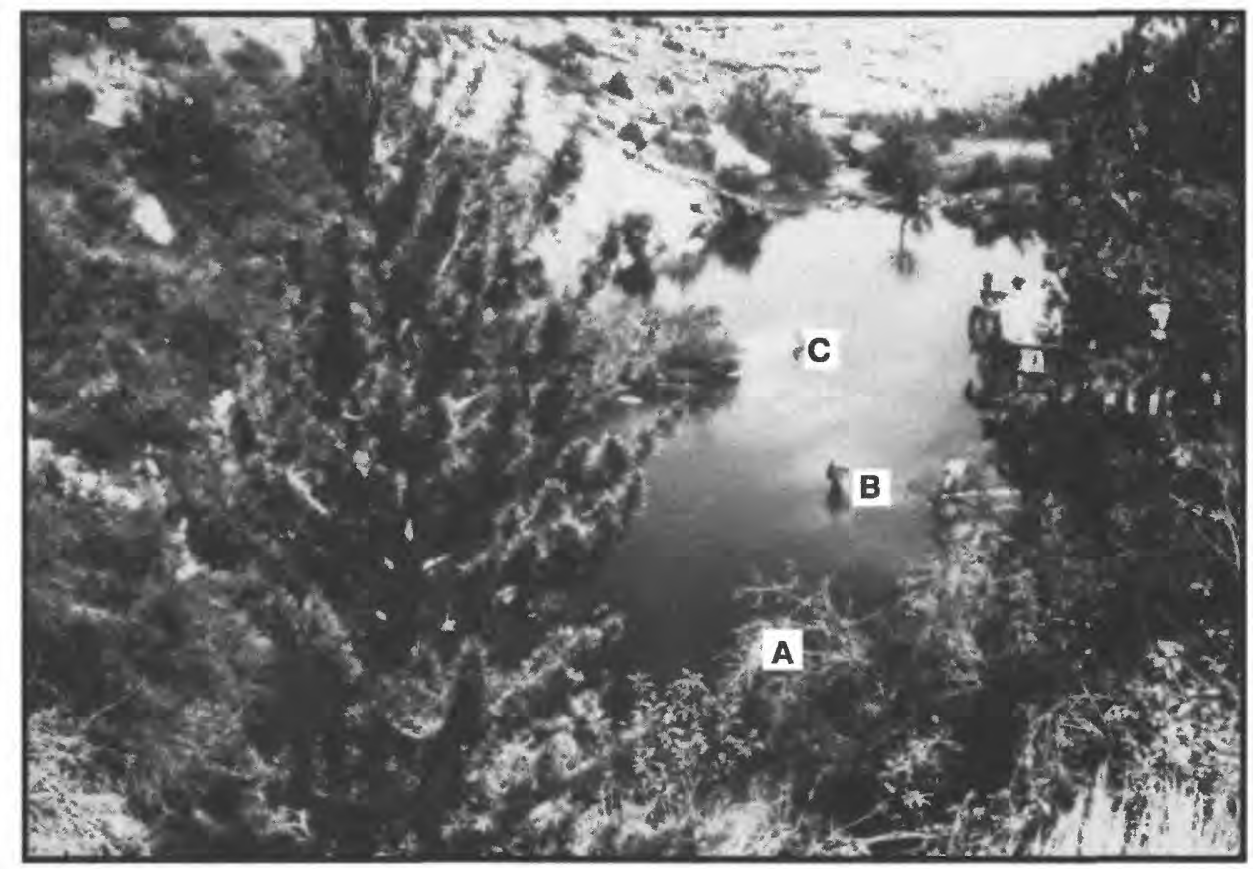

Figure 45. The Rise, Sinks Canyon State Park, August 14, 1983. View is downstream. Dye-sampling sites: A, Spring in pool at right side near upstream end of pool; B, Near right bank at old power plant; C, At sand bar at left bank near downstream end of pool. Photograph by Kerry Kelley, Wyoming Recreation Commission. 


\section{INVESTIGATIONS IN KARST TERRANE-Continued}

\section{Middle Popo Agie River in Sinks Canyon State Park, 1983-Continued \\ Results}

Time of Travel and Dispersion.-The primary result of the dye-tracer test is that the dye appeared at the Rise, proving the direct connection of the Rise to the Sinks. However, time-of-travel and dispersion information also was determined from the dyeresponse curves (fig. 46).

Time of travel of the dye between the injection site at the Sinks and the sampling site at the head of the pool at the Rise (a straight-line distance of about 3,500 feet) from figure 46 , is as follows:

$$
\text { - Leading edge of dye } 2 \text { hours }
$$

- Peak concentration of dye 2 hours, 40 minutes

- Trailing edge of dye 8 hours (approximate)

The passage time, or time for the dye to clear the pool after first appearance, was about 6 hours. Similar information for the other two sampling sites at the Rise may be determined from figure 46 .

The dye-response curves (fig. 46) depict the amount of dispersion that occurred between the injection and sampling sites. The curve for the upstream site is smooth because the samples were collected from a single spring. The unevenness of the curves at the two downstream sites may indicate the effect of uneven mixing of water from several points in the pool. The unusually long tails of the response curves are indicators of some sort of temporary storage in the underground part of the flow path (or paths).

Dye Recovery.- The amount of dye accounted for by sampling is an approximation of how much water entering the Sinks emerges directly at the Rise. For this test, dye recovery was calculated using $136 \mathrm{ft}^{3} / \mathrm{s}$, the discharge at the gaging station downstream from the Rise. Actual discharge at the Rise probably was slightly smaller. The areas under the dye-response curves in figure 46 were measured using a digitizer; the average for the three curves is 2,800 fluorometer units times seconds. The fluorescence of the diluted injection solution is $32 \times 10^{7}$ fluorometer units. The amount of dye accounted for is calculated to be $33.7 \mathrm{~mL}$, or 84 percent of the $40 \mathrm{~mL}$ injected.
Evaluation of the recovery data for the three sampling sites indicates the following:

- The dye was well mixed with the water flowing through the pool.

- The dye was well mixed in the water entering through springs in the bed of the pool.

- The amount of untagged water added by other springs near the pool must have been only a small part of the total flow of the pool.

Peak Concentration. - The value of the peak concentration of dye observed at the Rise was calculated. USGS requires that the peak concentration in any dye study be less than 10 micrograms per liter (10 parts per billion) at the downstream end of any study reach or at any intermediate site where water is withdrawn for use by humans (Wilson and others, 1986, p. 8).

Because the relations of fluorescence to concentration and fluorometer output to fluorescence both are linear for dilute solutions, peak concentration $\boldsymbol{c}$ is calculated using the simple proportion:

$$
\frac{c}{f}=\frac{C}{F} \text {. }
$$

Hence,

$$
c=\frac{C f}{F},
$$

where $\boldsymbol{c}$ is the peak concentration,

$\boldsymbol{f}$ is the fluorescence of the peak concentration ( 0.76 fluorometer unit in this test),

C is the concentration of the injection solution (0.24 kilogram per liter when adjusted for specific gravity, 1.2), and

$\boldsymbol{F}$ is the fluorescence of the injected solution (32 $\times 10^{7}$ fluorometer units in this test).

The calculated value of $c$ is $5.7 \times 10^{-10}$, or 0.57 microgram per liter-well below the limit of 10 micrograms per liter. This procedure amounts to a single-sample, direct calibration of the fluorometer. 
Discussion.-The dye test was successful because it proved the connection of the Rise to the Sinks. The conduit, or system of conduits, between the Sinks and the Rise may be very circuitous, both laterally and vertically, which could account for the long traveltime. Other conditions that could account for long traveltimes are a small hydraulic gradient and (or) temporary storage of dye in pools in the underground conduits. Future tests might be done to determine traveltimes and dilution during low and very high flows, or to determine the source of the additional water observed downstream from the Rise. In any test, measurement of the discharge of the river at the Rise would be useful for calculating dye recovery.
Possible sources of additional water include discharge from the Madison Limestone and discharge captured from an adjacent stream, Sawmill Creek (fig. 42), through an underground conduit. The increase in water temperature between the Sinks and the Rise is one indication of possible additional ground-water inflow. A systematic survey of water temperatures in the stream, pool, sidewall springs, and any local wells completed in the Madison Limestone, might be useful for interpreting the flow system. If most of the water entering the cave re-appears directly at the Rise, the dye and water not recovered could be accounted for by storage in the underground part of the flow system or by underground flow away from the study area.

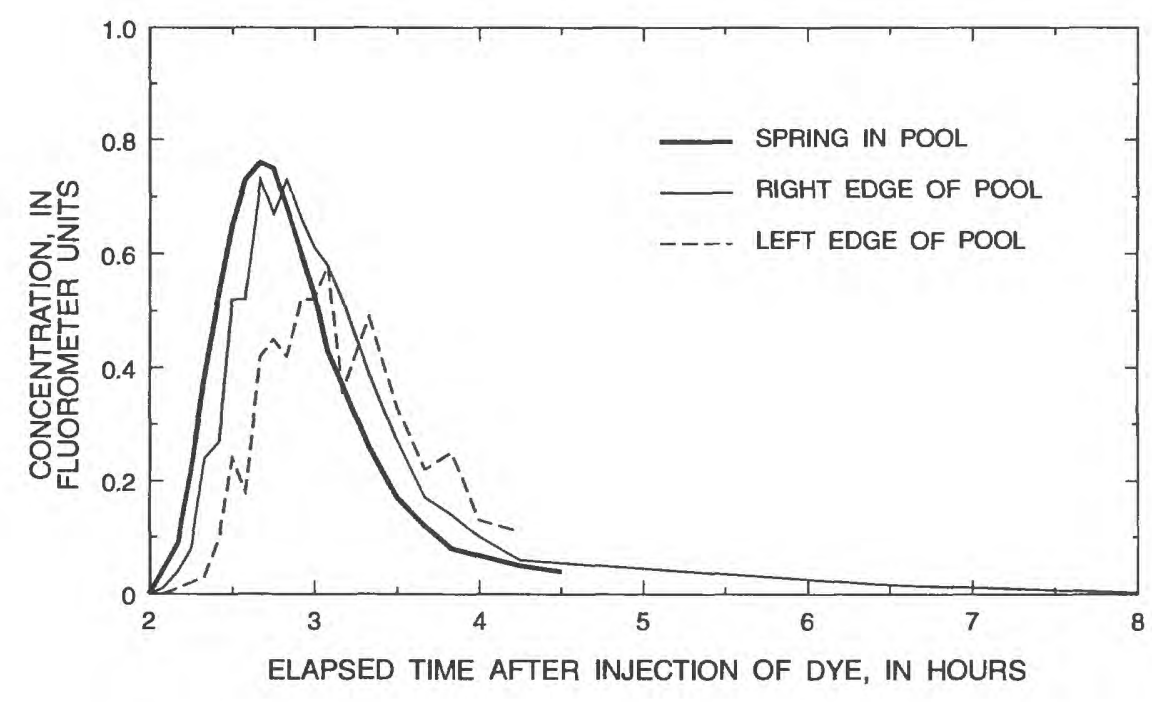

Figure 46. Dye-response curves in Middle Popo Agie River at the Rise, Sinks Canyon State Park, August 14, 1983. 


\title{
INVESTIGATIONS IN KARST TERRANE-Continued
}

\author{
Smith Creek below Otter Creek, 1991
}

[Investigation in cooperation with the Wyoming State Engineer]

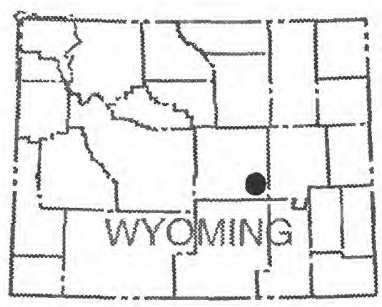

Base flow at the streamflow-gaging station on Smith Creek below Otter Creek (site 4, fig. 47) is sustained by discharge from limestone formations. A declining base flow during water years 1989-90 (fig. 48) raised concerns that water lost in the sinks in limestone downstream from the station above Otter Creek (site 1, fig. 47) did not return to the channel at the station below Otter Creek. To better understand the karst flow system in the vicinity of Smith and Otter Creeks, a dye test was done during 1991.

Streamflow records for water years 1988-91 were analyzed for stations 06645150, Smith Creek above Otter Creek, near Casper (site 1, fig. 47); 06645164, Otter Creek at mouth, near Casper (site 3); and 06645166, Smith Creek below Otter Creek, near Casper (site 4). Average flows for the 4 years indicate a 13-percent loss in water at Smith Creek below Otter Creek when the flows were compared to the combined flow of the two upstream stations. However, the 1990 records indicate a flow loss of 25 percent between the stations. A drought had occurred during that year.

Study Reach.-A geologic reconnaissance of the reach was made in 1974 (Boner and others, 1976, p. 15-16). The station upstream from Otter Creek (site 1, fig. 47; site 85 in Glass and Sultz, 1992) is near the contact of the Madison Limestone of Mississippian age and the underlying granite of Precambrian age. Smith Creek flows across, and nearly parallel to the strike of, the steeply dipping Madison for nearly
1 mile. At a point about 0.2 mile upstream from Otter Creek, the stream crosses the contact with the Casper Formation of Pennsylvanian and Permian age. The upstream station and a station at the Madison and Casper contact, 1.4 miles upstream from the station below Otter Creek (site 86 in Glass and Sultz, 1992; location not shown on fig. 47), were operated during 1975-79. Records indicate annual net flow losses ranging from 8 to 36 percent of the flow at the upstream station (Glass and Sultz, 1992, p. 105-108).

Dye Test.-Smith Creek at site 1 was sluginjected with $100 \mathrm{~mL}$ of a 20 -percent solution of rhodamine WT dye on September 19, 1991. The dye was observed to arrive 2.9 hours later at the sinks (site 2, fig. 47) about 0.8 mile downstream from site 1 . Some flow was lost between the point of injection and the main sinks.

Sampling was started at site 4 , about 2.8 miles downstream from site 1 , about 3.5 hours after injection. Two bottles of water per sample were collected at 30-minute intervals until dye was detected and less frequently thereafter.

One set of samples was analyzed onsite using a fluorometer. Under field conditions, with very low dye concentrations and varying light and temperature, the presence of dye in the samples could not be ascertained. The second set of samples was analyzed later in the laboratory under controlled light and temperature conditions. After background response was blanked out, a very weak dye response could be detected. Dye was detected in samples starting about 20 hours after injection and continuing for about 13 hours (fig. 49).

Calculation of the amount of injected dye recovered at Smith Creek below Otter Creek (site 4) was not possible because of the low concentrations, nor was it possible to determine what percentage of the water entering the sinks was recovered. The tracer study confirms a hydraulic connection between the sinks and the downstream station. 


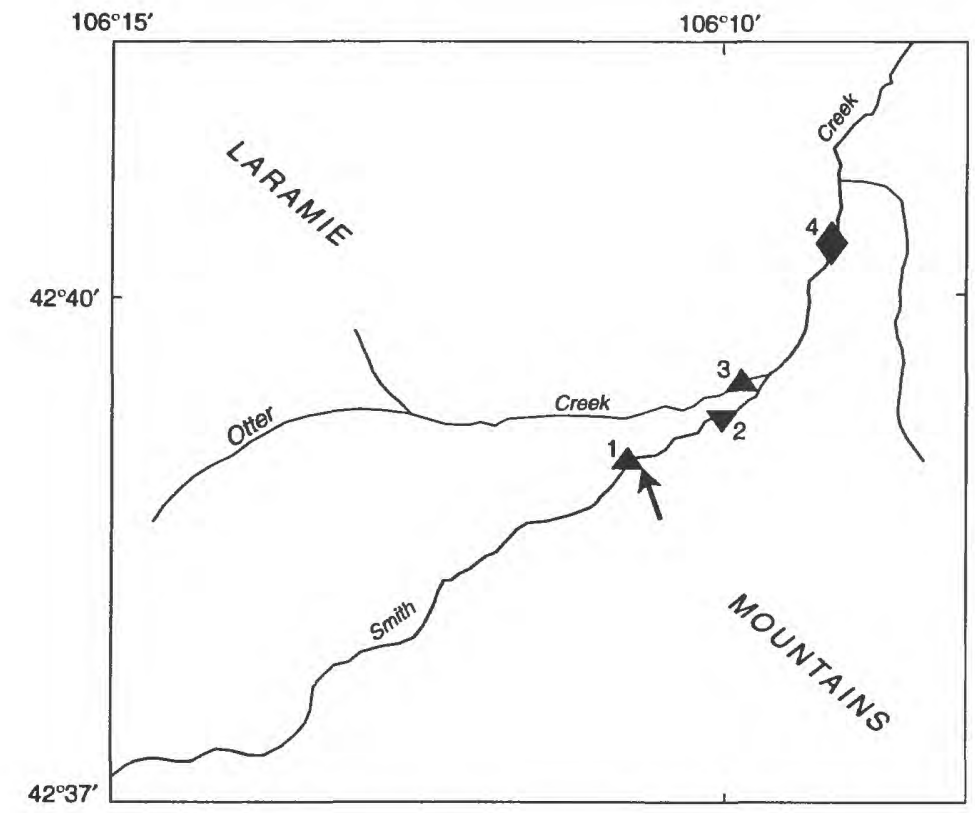

EXPLANATION

4. STREAMFLOW-GAGING

STATION AND SITE NUMBER

DYE-INJECTION SITE

$\nabla_{2}$ SAMPLING SITE AND NUMBER

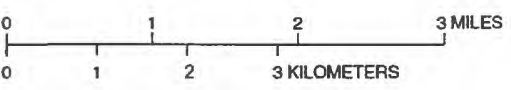

Figure 47. Location of streamflow-gaging stations and dye-injection and sampling sites, Smith Creek study area. Study reach is approximately 17 miles southeast of Casper, Wyoming.

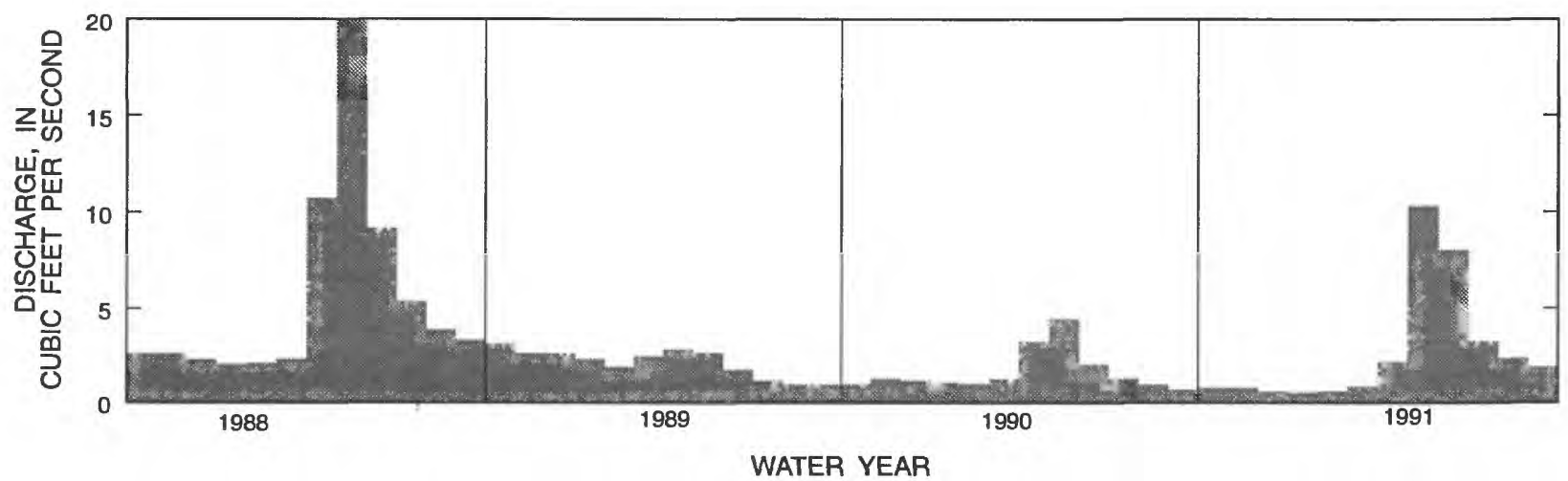

Figure 48. Monthly mean discharge at streamflow-gaging station 06645166, Smith Creek below Otter Creek, near Casper, Wyoming (site 4), water years 1988-91.

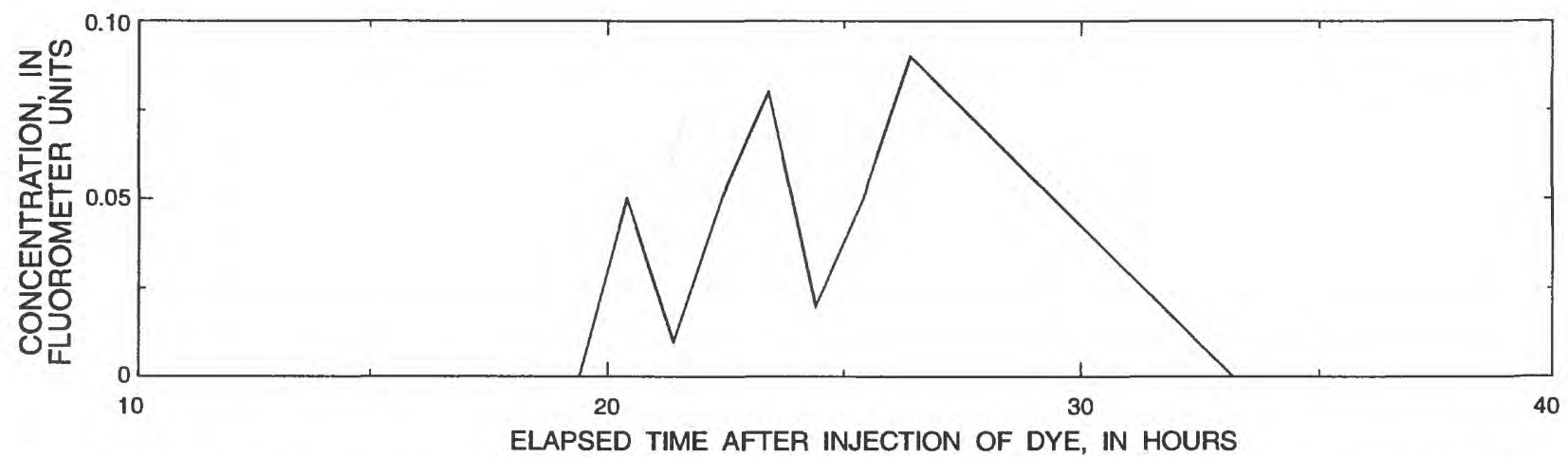

Figure 49. Dye-response curve in Smith Creek below Otter Creek (site 4), September 19-21, 1991. 


\section{OTHER INVESTIGATIONS}

\section{Methods}

The miscellaneous applications of dye tracing in the four units that follow do not fit into any of the previously discussed groups. Each dye test was unique; the investigator applied a general knowledge of dye tracing and some degree of ingenuity. Dye-injection and sampling procedures were adapted as necessary. The one feature all applications of dye tracing have in common, however, is the capability to detect the dye in extremely small concentrations (less than 0.5 microgram per liter) quickly and accurately.

Four dye tests are described in this group. In the Pass Creek test, a tracer dye was used to tag moving water for some other kind of measurement or sampling. The test in glacial deposits in Yellowstone National Park, discussed in the next unit, is the only groundwater application of dye tracing by the USGS in Wyoming to date that was not done in karst terrane. In the highway edgedrain test and the fire-protection training facility test, described in subsequent units, dye was used to detect leakage. For the highway test, dye was buried to detect storm runoff that might seep through the pavement, whereas the training-facility test was a direct check for a leak. 


\section{OTHER INVESTIGATIONS-Continued}

\section{Pass Creek Flow Tagging, 1967}

[Investigation in cooperation with the Wyoming State Engineer]

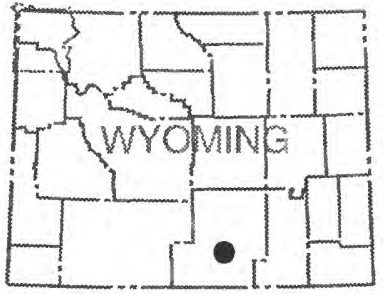

A dye test was made in Pass Creek at a site between Wyoming Highway 130 and the North Platte River (fig. 50) November 14, 1967, as part of an investigation of ground-water resources of a large area in south-central Wyoming. Marlin E. Lowry, USGS, Cheyenne, Wyo., was project chief.

The purpose of the dye test was to obtain information about the ground-water component of low flows. Stream discharge was measured with a current meter at several cross sections along a reach approximately 2 miles long, where the stream passes Stage Station Springs (fig. 50).

Because gains in streamflow from ground-water discharge between successive measurement sites were expected to be small, it was necessary to avoid discharge fluctuations from other causes, such as diurnal freezing and thawing of water in the stream. That can be done if the same water, together with any gains or losses, is measured at every site. Therefore, the water at the upstream site was tagged by injecting dye. The presence of the dye was monitored at downstream measurement sites by sampling and immediately testing the samples in a fluorometer. The current-meter measurements were timed to coincide with the passage of the dye cloud.

Although the data could not be found for inclusion in this report, the test indicated how dye tracing can be used as a tag for collecting other kinds of data, such as current-meter measurements. A similar use of dye tagging is in reaeration measurements. As previously described, dye and gas tracers are injected simultaneously. Timing of collection of water samples for analysis for dissolved propane is based on the presence of dye in the stream at the sampling site.

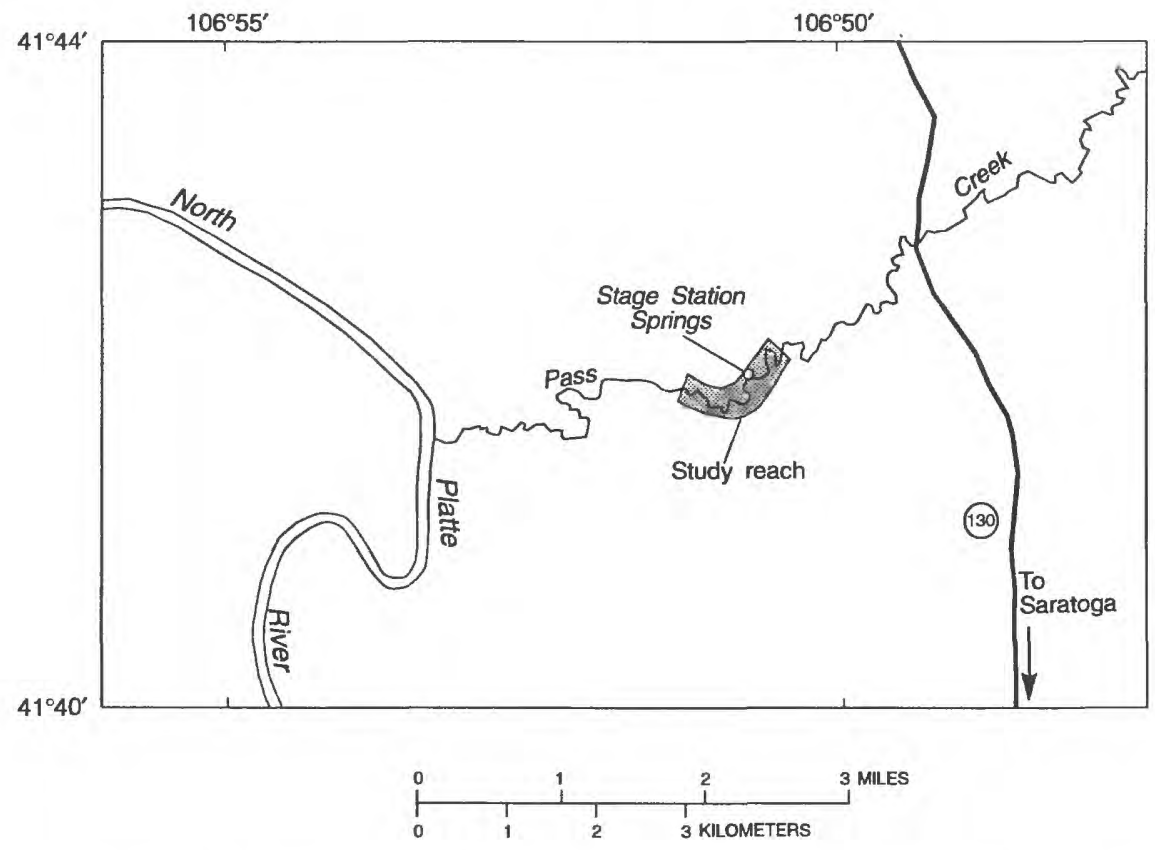

Figure 50. Location of study reach of Pass Creek. Study reach is approximately 17 miles north of Saratoga, Wyoming. 


\title{
OTHER INVESTIGATIONS-Continued
}

\author{
Old Faithful Wastewater Lagoon, 1975-76
}

[Investigation in cooperation with the National Park Service]

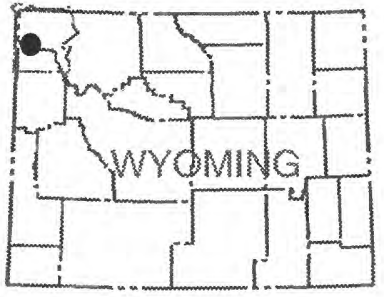

In 1974 the USGS began a hydrologic investigation at four wastewater treatment and disposal plants in Yellowstone National Park. Evaporation-percolation lagoons are used at the plants, which serve major visitor areas. Shallow nonthermal ground water and, in some places, discharging thermal water may move percolating effluents from the lagoons toward nearby streams and lakes. The purpose of the investigation was to determine the effects, if any, of the percolation on chemical quality of the surface waters. The results are reported by Cox (1986).

The investigation included a dye test at the Old Faithful wastewater treatment and disposal plant, which is built on a sand-and-gravel terrace about 40 feet higher than Iron Spring Creek (fig. 51). Waterlevel contours indicated that water in glacial deposits of Quaternary age beneath the terrace moved toward the stream (Cox, 1986, p. 54-55). Cox concluded that effluent percolating from the wastewater lagoons also moved toward Iron Spring Creek. The purpose of the dye test was to verify the direction of movement and estimate the rate of movement of the effluent. Most of the following discussion of the dye test is from Cox (1986, p. 60-61).

Rhodamine WT dye was injected in the southeasternmost lagoon on October 1, 1975. Water samples were collected about weekly from October 1, 1975 through April 25, 1976 from well OF 2, which is about 130 feet from the lagoon, and at the two sampling sites on Iron Spring Creek (fig. 51).
The leading edge of the dye plume arrived at well OF 2 on about October 15, and the peak concentration arrived on November 26, 1975 (fig. 52). The dye concentration, as indicated by fluorometer units, had decreased to the natural, or background level of fluorometer response by about April 20, 1976. The average time of travel of the dye is calculated as the concentration-weighted average (the time of the centroid of the response curve, fig. 52). Therefore, the average traveltime for the dye between the lagoon and the well was about 65 days, and the velocity of the dye is estimated to be about 2 feet per day.

The sampling data for Iron Spring Creek are inconclusive. Cox (1986, p. 60) states that the dye probably reached Iron Spring Creek (at least 400 feet from the lagoon) between the two sampling sites, but in very diluted concentrations, only slightly above background levels (fig. 52). Given a velocity of about 2 feet per day, the main part of the dye plume possibly had not reached the stream when sampling was discontinued. The small increases in fluorometer readings at the site downstream from the lagoons could indicate fluorescence of dye, but they also could have been caused by turbidity of the samples. False-positive readings for dye can occur in a fluorometer when light is scattered by suspended materials (Wilson and others, 1986, p. 19). Turbidity of the water could have been caused by precipitates of iron compounds (described by Cox, 1986, p. 62) or other constituents from the wastewater effluent mixed with the ground water. Cox used chloride concentrations and specific conductances of water in wells and the stream to verify the discharge of effluent into Iron Spring Creek between the two stream-sampling sites (Cox, 1986, p. 56-59). Chloride probably is a more conservative tracer than rhodamine WT dye, which sorbs to sediments, especially clays. 


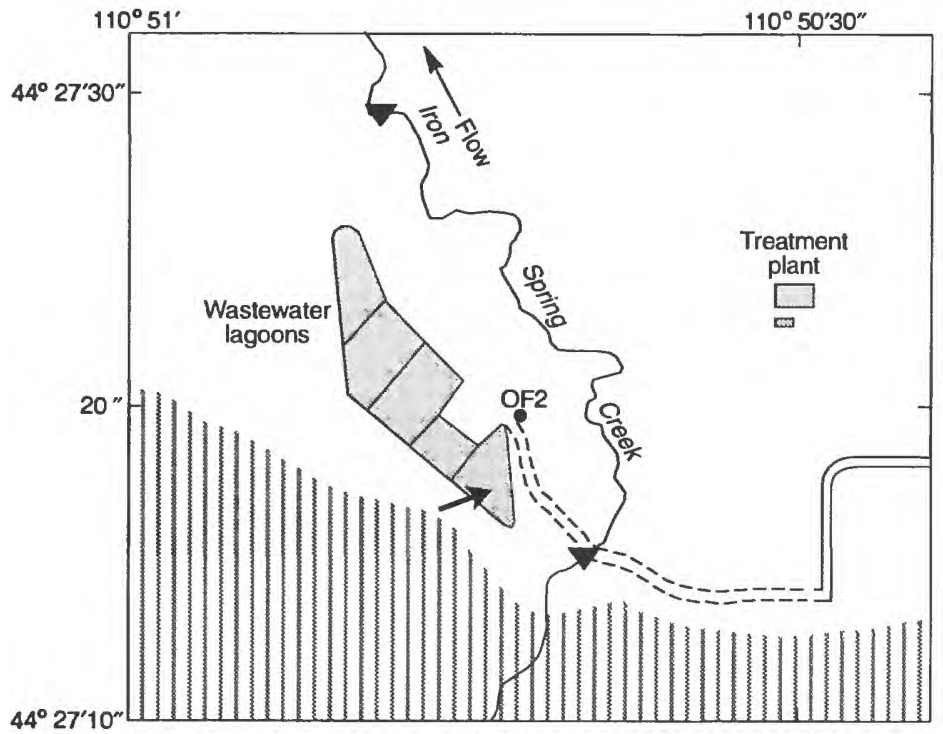

EXPLANATION

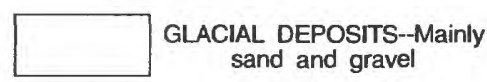

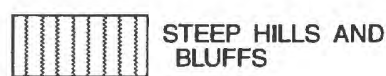
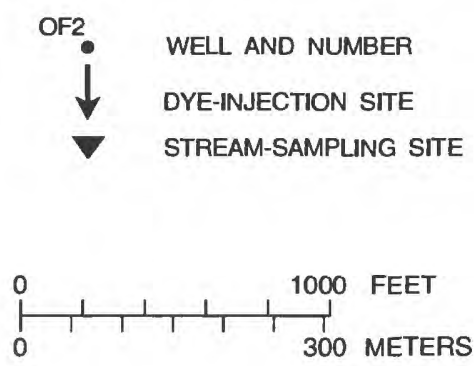

Figure 51. Location of well OF2 and stream-sampling sites near the Old Faithful wastewater lagoons, Yellowstone National Park (modified from Cox, 1986, p. 57).

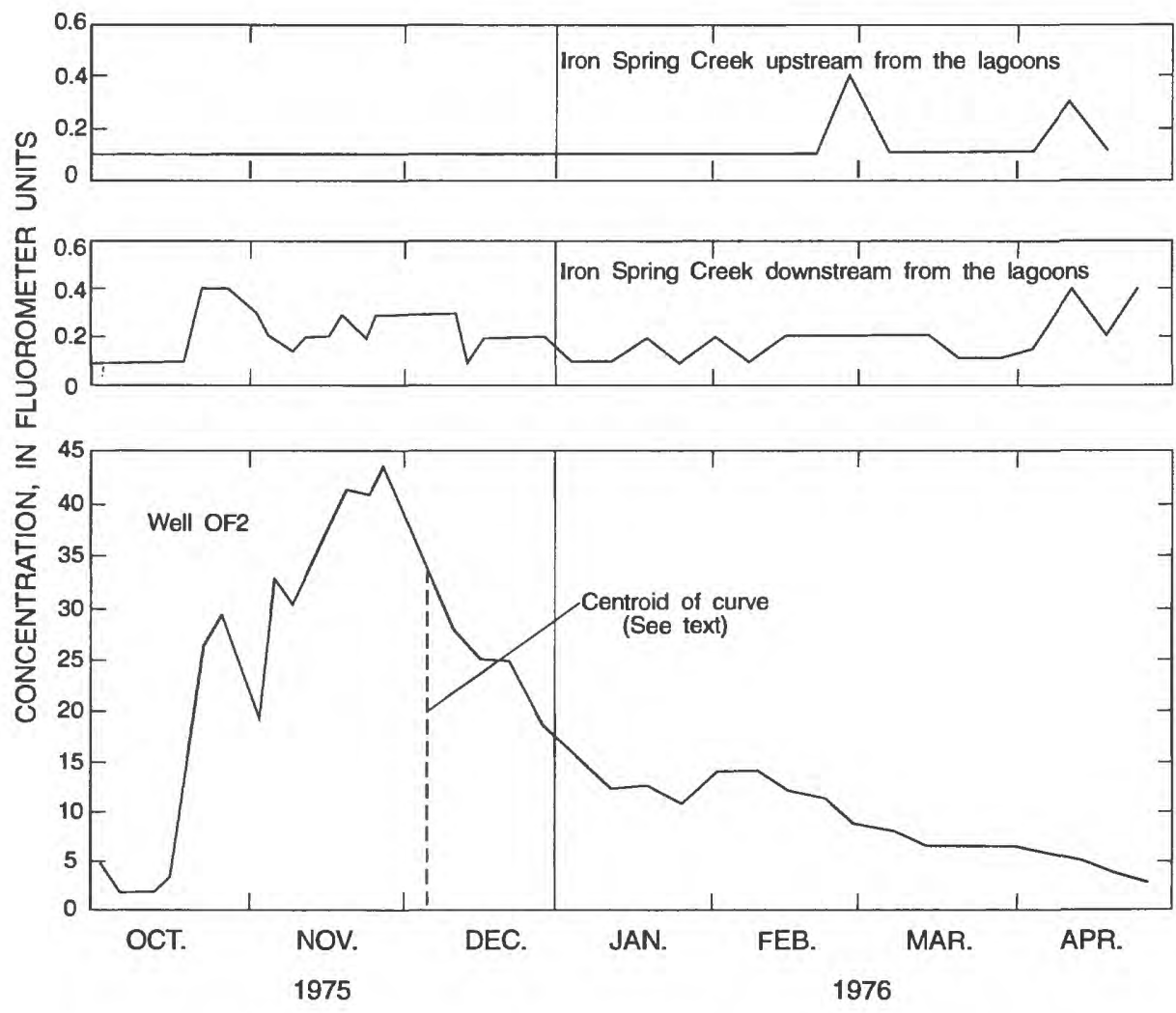

Figure 52. Dye-response curves in well OF2 and Iron Spring Creek near the Old Faithful wastewater lagoons, October 1, 1975 through April 25, 1976 (modified from Cox, 1986, fig. 54). 


\title{
OTHER INVESTIGATIONS-Continued
}

\author{
Interstate Highway 25 Edgedrain Test, 1989
}

[Investigation in cooperation with the Federal Highway Administration]

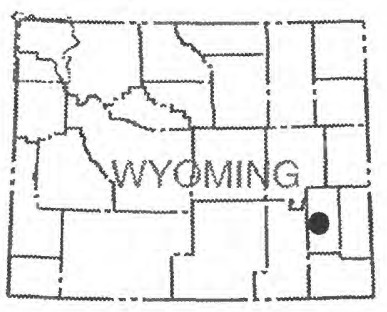

This test was part of a national evaluation of retrofitted edgedrains on Federal highways by the USGS (Jeffcoat and others, 1992). Retrofitted edgedrains are entrenched longitudinal drains placed along pavement margins some years after construction of the highway. As a highway ages, seepage of water from precipitation through joints and cracks in the pavement increases, leading to accelerated deterioration of a highway. Edgedrains have been retrofitted on many highways to help drain the underside of the pavements.

Sites in 10 States, including a site on Interstate Highway 25 near Wheatland, Wyo. (fig. 53) were instrumented to monitor rainfall, edgedrain runoff, piezometric water levels, and subbase moisture, as a means of evaluating the effectiveness of retrofitted edgedrains in removing water from the highway surface and subsurface. Kent D. Becher, USGS, Casper, Wyo., was coordinator for the work near Wheatland.
A dye test was a minor part of the investigation at each site. A 1-inch diameter hole was drilled through the pavement and into the subbase (fig. 54). During the second week of August 1989, approximately $50 \mathrm{~mL}$ of rhodamine WT dye was poured into the hole, and the hole was sealed. During periodic visits to the site, samples of water discharging from the edgedrain were obtained for fluorometric analysis.

At the test sites in 9 of the 10 States, including the Wyoming site, results were negative: there was no evidence of dye in the discharge water. At the North Carolina site, however, dye appeared shortly after emplacement, but the dye hole was known to have intercepted voids in the subgrade material beneath an aggregate subbase. Jeffcoat and others (1992, p. 75) concluded that, because no obvious voids or channels in the subbase or subgrade were intercepted by the drill holes at the other nine sites, the lack of permeability in the subbases (confirmed by laboratory tests) inhibited water movement. Water discharged through the edgedrain was from direct runoff and seepage through pavement joints and cracks. This "negative" result may be useful for future design of highways, as it is one indicator of poor drainage of subsurface water in tight, low-permeability subbase or subgrade materials (Jeffcoat and others, 1992, p. 78). 

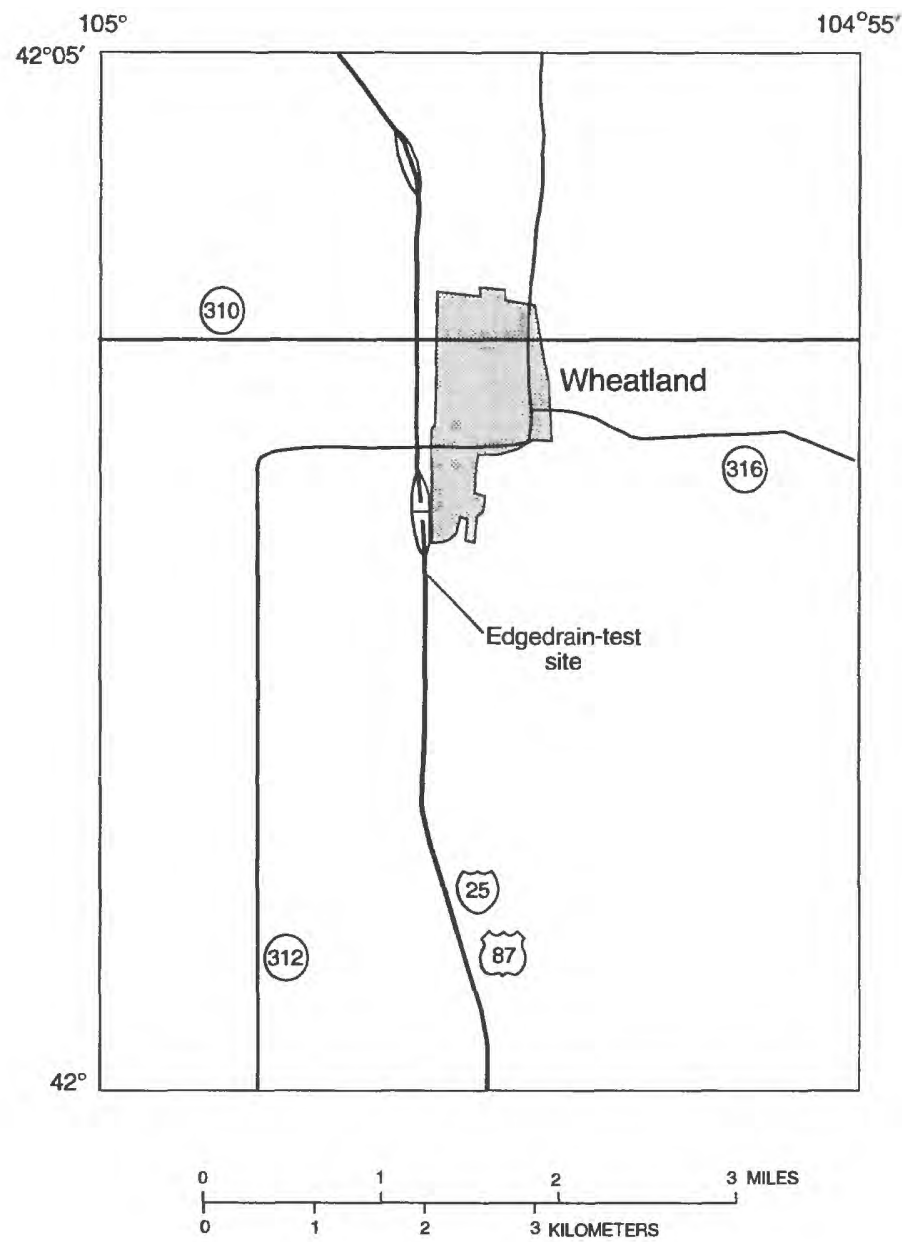

Figure 53. Location of the edgedrain-test site on Interstate Highway 25.

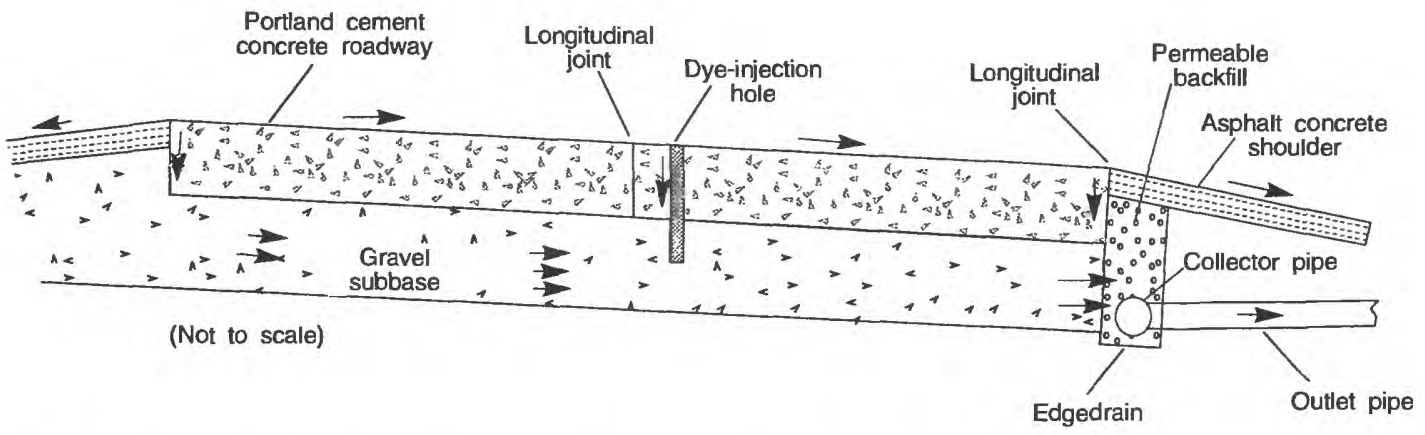

Figure 54. Generalized transverse section of northbound lanes of Interstate Highway 25 showing retrofitted edgedrain and dye-injection hole (modified from Jeffcoat and others, 1992, fig. 32). Arrows indicate direction of flow. 


\title{
OTHER INVESTIGATIONS-Continued
}

\section{F.E. Warren Air Force Base Fire-Protection Training Area, 1990}

\author{
[Investigation in cooperation with the U.S. Air Force]
}

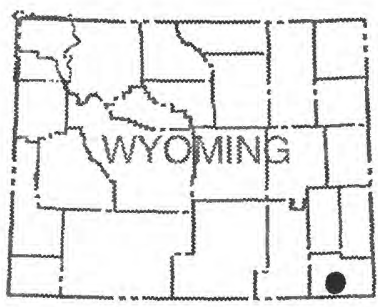

A brief but successful dye test at one of the fireprotection training areas at F.E. Warren Air Force Base during 1990 illustrates the versatility of dye tracing. The base is located adjacent to Cheyenne (fig. 55). Since 1985 the USGS has been conducting an extensive hydrologic investigation to determine the nature and extent of hazardous materials in the soil and water at the base. The dye test, not related to the hydrologic investigation, was coordinated by L. Rodney Larson, USGS, Cheyenne, in response to a request from Air Force engineers.

The fire-protection training area in use during 1990 was an outdoor facility where firefighters practice extinguishing fires, mainly using aqueous film-forming foam (AFFF). The runoff of water and AFFF is collected in a double-lined retention pond (fig. 56). Air Force engineers suspected a leak in the inner (upper) liner. USGS personnel concluded that a dye test might verify the existence of a leak.

Water in the retention pond, which is shaped like an inverted truncated square pyramid, was about 4 feet deep when the dye test was performed. The volume of water in the pit was estimated to be about 7,200 cubic feet, or about 200,000 liters. It was decided to inject 0.2 liter of rhodamine WT dye; if that amount were completely mixed with the water in the pit, the concentration in the pit would be about 1 milligram per liter (part per million). That concentration would be easily detected in water pumped from the space between the two liners.

The dye was poured into the retention pond September 18, 1990. First, the dye was mixed with about 3 liters of pond water in a plastic bucket. Then the bucket was attached to ropes, and with a person on each side of the pit holding a rope, the dye was spread across the water surface. By the following morning, the dye appeared to be evenly dispersed throughout the pond.

On September 19, Air Force personnel began pumping water from the leakage-monitoring station (fig. 56), a 10-inch cased piezometer well connected horizontally to the space between the two liners. A water sample was collected from the well prior to pumping. Nine samples were collected from the well at varying time intervals during 5 hours of pumping. As shown in figure 57, there was a strong presence of dye in the water pumped from the space between the liners, proving the existence of a leak and providing the Air Force with the information needed to arrange for repair under the contract warranty.
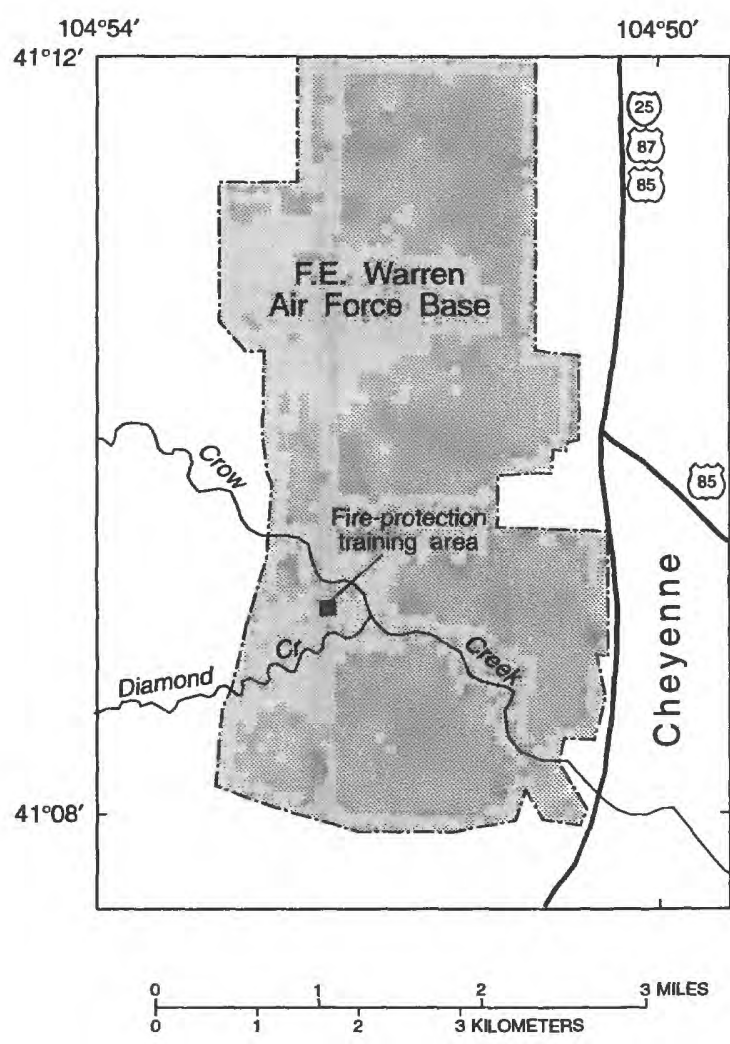

Figure 55. Location of fire-protection training area, F.E. Warren Air Force Base. 


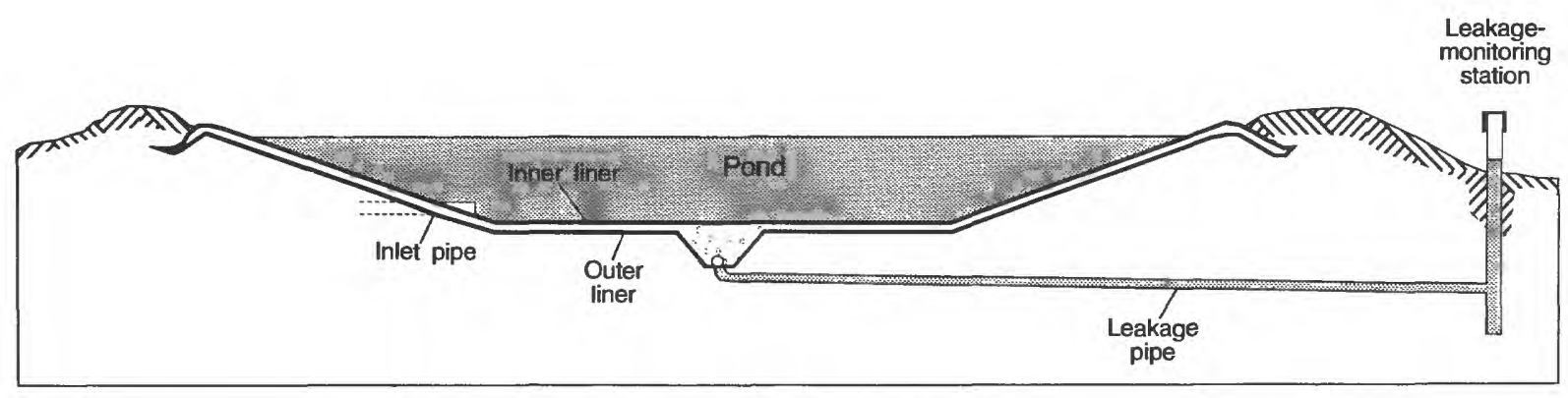

Scale (approximate): 1 inch $=15$ feet

Figure 56. Cross-sectional sketch of retention pond in fire-protection training area (from drawings provided by U.S. Air Force).

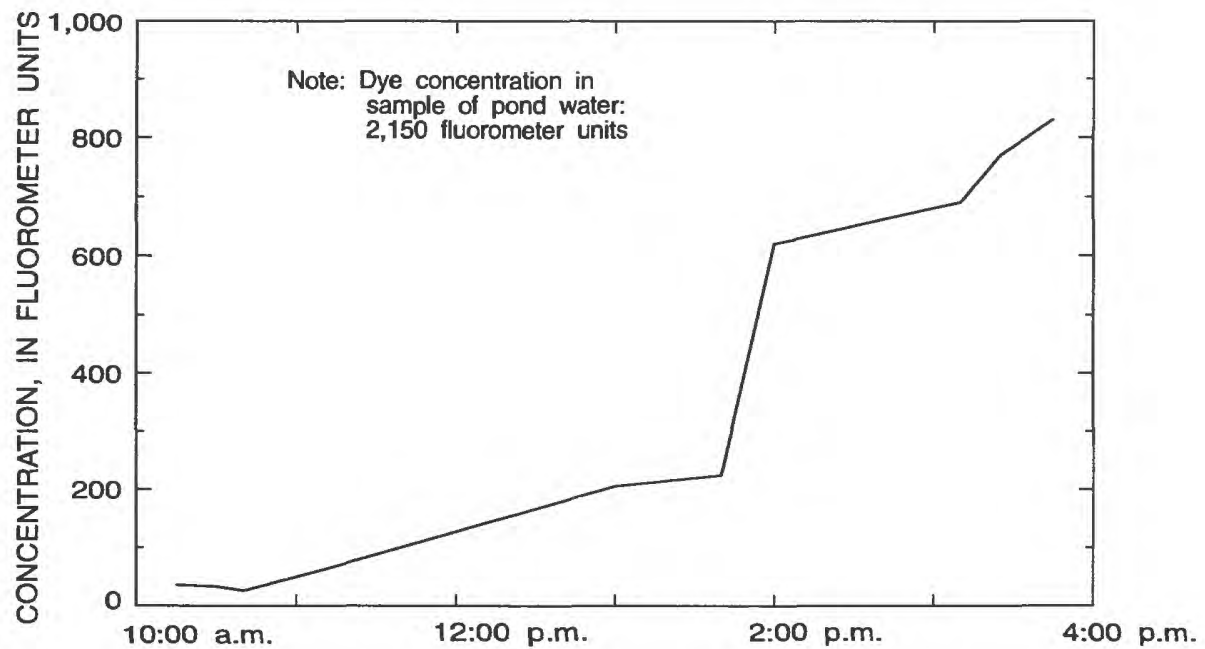

Figure 57. Dye-response curve for water pumped from leakage-monitoring station at retention pond in fire-protection training area, September 19, 1990. 
For nearly three decades, U.S. Geological Survey hydrologists and technicians, in cooperation with State and other Federal agencies, have been using small quantities of rhodamine WT dye to trace flowing water in Wyoming. Each of the many applications of dye tracing in Wyoming during 1967-94 is described in this report. Previously published investigations are summarized, and previously unpublished investigations are described in greater detail. The applications of dye tracing range from measurements of time of travel and dispersion in stream reaches more than 100 miles long, to measurements of the discharge of small mountain streams when the flow was too swift and turbulent to measure by traditional methods. In some investigations the objective was to determine the destination of surface water lost to the subsurface. Collectively, this series of articles illustrates the versatility and simplicity of dye tracing in water-resources investigations.

\section{Time of Travel and Dispersion of Solutes in} Streams. - Measurements of time of travel and dispersion in long reaches have been conducted for the Wind/Bighorn River between Boysen Dam and the town of Greybull, most of the Green River and four of its tributaries upstream from Flaming Gorge Reservoir, the Little Snake River along the Wyoming-Colorado State line, and the North Platte River between the city of Casper and Glendo Reservoir. The measurements provided information that water managers can use in response to accidental spills of harmful materials along highways, railroads, or pipelines adjacent to the streams or their tributaries-particularly the Wind/ Bighorn and North Platte Rivers. In addition, the information can be used to calculate water velocities that are more representative of long reaches than velocities measured only at stream cross sections, an objective of the measurements of the Green River and tributaries and the Little Snake River. The data from the measurements of the Wind/Bighorn River also were used in research studies of dispersion of solutes in flowing water. Previously published regression equations calculated using data from streams throughout the United States accurately predicted time of travel of the dye injected into the North Platte River in 1985.
Additional interpretation of the time-of-travel and dispersion data previously collected is possible. Dispersion information for unsteady flow or highly variable reach hydraulics can be determined accurately from the tracing data by applying numerical routing procedures. Published techniques also are available for simulating soluble-waste transport from a known or planned point source near any of the dye-tested streams.

\section{Reaeration coefficients in Streams.-}

Reaeration coefficients have been determined only for a 40-mile reach of the North Platte River, starting at the city of Casper. The reaeration coefficients calculated from dye- and gas-tracer data for steady flow were used by the Wyoming Department of Environmental Quality to assess the capacity of the river to assimilate municipal organic waste without depleting the supply of dissolved oxygen. Reaeration coefficients for unsteady flow in the study reach of the North Platte River may be estimated using a numerical routing model calibrated with the previously collected dye- and gas-tracing data.

\section{Dye-Dilution Discharge Measurements.-} Seventy dye-dilution discharge measurements were made during 1967-82. Dye-dilution discharge measurements are useful where current-meter measurements of stream discharge are difficult or impossible, or independent verification of such measurements is needed. As a part of USGS national research to develop methods, five test measurements were made in the Laramie River during February 1967 to test the method in a stream covered by ice. Four of the five measurements under ice were within 2 percent of the discharge measured by current meter in an ice-free reach. Next, an investigation of the methods was conducted at streamflow-gaging stations on North and South Brush Creeks during 1967-68. Seventeen dyedilution discharge measurements were made, confirming the stage-discharge rating curves previously developed using current-meter measurements. Four dye-dilution measurements were made at a streamflow-gaging station on South Piney Creek during 1971-74, with similar success. With confidence in the dye-dilution method thus established, hydrographers proceeded to use the method at other sites. 
In 1975, USGS hydrographers in Wyoming were faced with the problem of measuring discharge at streamflow-gaging stations on the east flank of the Bighorn Mountains during spring runoff, where there were no cableways or bridges from which to suspend a current meter. The stations were operated to estimate streamflow recharge to the Madison Limestone of Mississippian age. Equipment and water samples had to be compact and lightweight for backpacking to and from the remote sites.

Twenty-nine dye-dilution measurements were made for the Madison study during 1975-78, including four additional measurements at the station on South Piney Creek, with results of varying accuracy. Most were used to define the stage-discharge rating curves for the stations, but a few were judged to be inconsistent with previous current-meter measurements at the site and were not used. At some stations the dye measurements were essential for developing the highflow part of the ratings and, therefore, the high-flow records for the station. The stage-discharge relation for Tongue River at Tongue Canyon Campground, near Dayton, where current-meter measurements could be made from a footbridge, was verified by four dyedilution discharge measurements, two of which were the largest to date (early 1996). The largest was $2,300 \mathrm{ft}^{3} / \mathrm{s}$.

At a few sites the accuracy of the dye-dilution measurement was downgraded, either because the dyeinjection rate was unsteady, or because lateral mixing was not uniform or could not be ascertained from the stream samples. Consequently, sampling procedures have been changed to assure collection of samples near the opposite streambank for better assessment of lateral mixing. After 1978 only two dye-dilution measurements were made, both to define the high end of the stage-discharge rating at a streamflow-gaging station on Middle Creek at East Entrance, Yellowstone National Park.

\section{Investigations in Karst Terrane.-USGS} hydrologists conducted dye tests in five streams in karst terrane during 1970-91. Streams on the flanks of mountain ranges in Wyoming commonly cross limestones and dolomites of Paleozoic age. Karst terrane, including sinkholes, caves, and springs, has developed in many places where dissolution of the carbonate rock has occurred. Some streams lose water into sinkholes or caves, or gain water from springs. Dye tests can provide information that water managers can use to understand the loss or gain as to its destination or source when allocating the affected water resources. Each of the five dye tests in karst terrane was successful, but each also raised questions that might be resolved with additional dye tests.

Dye was injected upstream from sinkholes in the North Fork Powder River below Dullknife Reservoir during 1970 to evaluate losses of water released for irrigation. Only about 6 percent of the injected dye was accounted for by sampling flow from a large spring about 3.7 miles downstream from the injection site. During the test, flow at the spring increased in response to the reservoir release, then decreased. About 86 percent of the flow entered the sinkholes. Results of the dye test do not explain: (1) the decrease in flow from the spring, (2) the connection of a second losing reach to the spring, and (3) the fate of most of the dyetagged water lost into the streambed.

Losing reaches of North Fork Crazy Woman Creek and the Little Tongue River were dye-tested during 1974 as part of the study of streamflow recharge to the Madison Limestone. In the 1.3-mile reach between two streamflow-gaging stations on North Fork Crazy Woman Creek there were three zones of streamflow loss. Dye arrived at the downstream station in separate peaks $3.50,6.75$, and 9.50 hours after injection at the upstream station. About 73 percent of the dye was accounted for by sampling, indicating that some water may have bypassed the sampling site. Discharge increased 9 percent, however, indicating an additional source of ground-water discharge to the stream.

The test of the Little Tongue River was conducted to determine how much of the water lost into the streambed resurges in Tongue River Cave (and eventually the Tongue River), some 2.6 miles north of and 2,500 feet lower than the losing reach. A single peak concentration of dye arrived in the stream in the cave 34 hours after injection, but only 35 percent of the dye was accounted for, indicating that only part of the water lost into the streambed reaches the cave. There is a 2-mile gap between the point where the stream loses all flow and the point where flow resumes in the Little Tongue River, a site not sampled for the presence of dye. The upstream losing reach might be the source of this water. For the study of recharge to the Madison Limestone, the results of the dye test serve as a reminder that streamflow losses do not always represent recharge. 
A 1983 dye test in the Middle Popo Agie River in Sinks Canyon State Park confirmed the direct connection of the Sinks (the cave where the river disappears) to the Rise (springs about 3,500 feet downstream where flow in the river resumes). The leading edge of dye injected upstream from the Sinks appeared at the Rise after 2 hours; the dye cloud had cleared the Rise after an additional 6 hours. Between the Sinks and the Rise discharge increased from about $81 \mathrm{ft}^{3} / \mathrm{s}$ to $136 \mathrm{ft}^{3} / \mathrm{s}$, and water temperature increased about $8^{\circ} \mathrm{C}$, indicating an additional source of ground-water discharge. About 84 percent of the dye was accounted for, indicating possible diversion of some water in the subterranean part of the flow system. An adjacent stream, Sawmill Creek, might be the source of some of the water gained.

Dye was used in 1991 to help evaluate water losses to sinks between two streamflow-gaging stations on Smith Creek near Casper. A very weak trace appeared at the downstream station about 20 hours after injection of dye at the upstream station, indicating a hydraulic connection between the sinks and flow at the downstream station. Because a dye-recovery calculation could not be made, the amount of water lost to the sinks and regained at the downstream station could not be estimated.

Other Investigations. - Four applications of dye tracing do not fit into any of the previously discussed groups. These investigations illustrate the potential for using dye tracing creatively when opportunities occur.

One of the earliest uses of dye tracing in Wyoming was in 1967 in Pass Creek near its mouth at the North Platte River. Dye was used as a tag, so as to make current-meter measurements of the same water at successive cross sections. Thus, small gains in stream discharge from ground water would not be obscured by other variations in streamflow. Water tagging with dye also can be used to assure correctly timed collection of water samples for other purposes, such as gas-tracer samples for reaeration measurements.

Dye was used in Yellowstone National Park during 1975-76 to measure the direction and rate of movement of effluent percolating from the Old Faithful wastewater-treatment facility through sand and gravel deposits toward a nearby stream. The average velocity of the dye plume between the wastewater lagoon injected with dye and a shallow well about 130 feet away was about 2 feet per day. Dye was detected in the well for nearly 7 months. The dye probably reached Iron Spring Creek, about 400 feet from the lagoon, but fluorometric responses in samples from the stream were only slightly above background levels. If the dye plume traveled at 2 feet per day, it may not have reached the stream when sampling was discontinued.

As part of a national study of the effectiveness of retrofitted highway edgedrains, in 1989 dye was placed in a sealed hole in the pavement of Interstate Highway 25 near Wheatland. The purpose was to detect runoff water seeping through the roadway subgrade. The dye was not detected in the discharge from the edgedrain, however, probably because of the lack of voids in the low-permeability subgrade.

In 1990 an active test for leakage was conducted at a fire-protection training facility at F.E. Warren Air Force Base near Cheyenne. The Air Force suspected a leak in the upper liner of a double-lined pond used to retain fire-fighting foam. Dye injected into the pond was detected in water pumped from a piezometer well connected to the space between the two liners, confirming the leak. 


\section{REFERENCES}

Armentrout, J.G., Jr., and Larson, L.R., 1984, Time of travel and dispersion of solutes in a 36.4-mile reach of North Platte River downstream from Casper, Wyoming: U.S. Geological Survey Water-Resources Investigations Report 82-4103, $17 \mathrm{p}$.

Bauer, D.P., Rathbun, R.E., and Lowham, H.W., 1979, Traveltime, unit-concentration, longitudinal-dispersion, and reaeration characteristics of upstream reaches of the Yampa and Little Snake Rivers, Colorado and Wyoming: U.S. Geological Survey Water-Resources Investigations Report 78-122, 66 p.

Boner, F.C., Lines, G.C., Lowry, M.E., and Powell, J.E., 1976, Geohydrologic reconnaissance and measurement of perennial streams crossing outcrops of the Madison Limestone, northeastern Wyoming, 1974: U.S. Geological Survey Open-File Report 75-614, 63 p.

Boning, C.W., 1974, Generalization of stream travel rates and dispersion characteristics from time-of-travel measurements: U.S. Geological Survey Journal of Research, v. 2, no. 4, p. 495-499.

Cox, E.R., 1986, Wastewater movement near four treatment and disposal sites in Yellowstone National Park, Wyoming: U.S. Geological Survey Water-Resources Investigations Report 84-4356, 81 p.

Glass, W.R., and Sultz, L.G., 1992, Summary of data indicating gain or loss of streamflow across outcrops of Paleozoic formations in northeastern Wyoming: U.S. Geological Survey Open-File Report 92-72, 136 p.

Hill, Chris, Sutherland, Wayne, and Tierney, Lee, 1976, Caves of Wyoming: Laramie, The Geological Survey of Wyoming Bulletin 59, 230 p., 4 map sheets.

Jeffcoat, H.H., Kilpatrick, F.A., Atkins, J.B., and Pearman, J.L., 1992, Effectiveness of highway edgedrains: U.S. Geological Survey Water-Resources Investigations Report 92-4147, 79 p.

Jobson, H.E., 1987, Prediction of dispersion and first-order rate coefficients by numerical routing: American Geophysical Union, Water Resources Research, v. 23, no. 1, p. 169-180.

1996, Estimation of traveltime and longitudinal dispersion in rivers and streams: U.S. Geological Survey Water-Resources Investigations Report 96-4013, 69 p.

Kilpatrick, F.A., 1993, Simulation of soluble waste transport and buildup in surface waters using tracers: U.S. Geological Survey Techniques of Water-Resources Investigations, book 3, chap. A20, 37 p.
Kilpatrick, F.A., and Cobb, E.D., 1985, Measurement of discharge using tracers: U.S. Geological Survey Techniques of Water-Resources Investigations, book 3, chap. A16, 52 p.

Kilpatrick, F.A., Rathbun, R.E., Yotsukura, Nobuhiro, Parker, G.W., and DeLong, L.L., 1989, Determination of stream reaeration coefficients by use of tracers: U.S. Geological Survey Techniques of Water-Resources Investigations, book 3, chap. A18, 52 p.

Kilpatrick, F.A., and Wilson, J.F., Jr., 1989, Measurement of time of travel in streams by dye tracing: U.S. Geological Survey Techniques of Water-Resources Investigations, book 3, chap. A9 (revised), $27 \mathrm{p}$.

Love, J.D., Christianson, A.C., and Ver Ploeg, A.J., compilers, 1993, Stratigraphic chart showing phanerozoic nomenclature for the State of Wyoming: Laramie, The Geological Survey of Wyoming Map Series, MS-41, 1 sheet.

Lowham, H.W., 1982, Streamflows and channels of the Green River basin, Wyoming: U.S. Geological Survey Water-Resources Investigations Report 81-71, 73 p.

Lowham, H.W., and Wilson, J.F., Jr., 1971, Preliminary results of time-of-travel measurements on Wind/ Bighorn River from Boysen Dam to Greybull, Wyoming: U.S. Geological Survey Open-File Report $71-85,7 \mathrm{p}$.

Lowry, M.E., and Cummings, T.R., 1966, Ground-water resources of Sheridan County, Wyoming: U.S. Geological Survey Water-Supply Paper 1807, $77 \mathrm{p}$.

Lowry, M.E., Lowham, H.W., and Lines, G.C., 1976, Water resources of the Bighorn basin, northwestern Wyoming: U.S. Geological Survey Hydrologic Investigations Atlas HA-512, scale 1:250,000, 2 sheets.

Mull, D.S., Liebermann, T.D., Smoot, J.L., and Woosley, L.H., Jr., 1988, Application of dye-tracing techniques for determining solute-transport characteristics of ground water in karst terranes: Atlanta, Ga., U.S. Environmental Protection Agency report EPA 904/6-88-001, 103 p.

Nordin, C.F., Jr., and Sabol, G.V., 1974, Empirical data on longitudinal dispersion in rivers: U.S. Geological Survey Water-Resources Investigations Report 20-74, $372 \mathrm{p}$. 
Nordin, C.F., Jr., and Troutman, B.M., 1980, Longitudinal dispersion in rivers: The persistence of skewness in observed data: Water Resources Research, v. 16, no. 1, p. 123-128.

Peterson, D.A., 1988, Streamflow characteristics of the Missouri River basin, Wyoming, through 1984: U.S. Geological Survey Water-Resources Investigations Report 87-4018, $429 \mathrm{p}$.

Pritchard, D.W., and Carpenter, J.H., 1960, Measurements of turbulent diffusion in estuarine and inshore waters: International Association of Scientific Hydrology Bulletin No. 20, p. 37-50.

Rankl, J.G., and Carnevale, M.A., 1989, Traveltime and reaeration coefficients for the North Platte River, Casper to Orin, Wyoming: Cheyenne, Wyoming Department of Environmental Quality report, $34 \mathrm{p}$.

Rathbun, R.E., and Grant, R.S., 1978, Comparison of the radioactive and modified techniques for measurement of stream reaeration coefficients: U.S. Geological Survey Water-Resources Investigations Report 78-68, 57 p.

Rathbun, R.E., Shultz, D.J., and Stephens, D.W., 1975, Preliminary experiments with a modified tracer technique for measuring stream reaeration coefficients: U.S. Geological Survey Open-File Report 75-256, 36 p.

Rathbun, R.E., Stephens, D.W., Shultz, D.J., and Tai, D.Y., 1978, Laboratory studies of gas tracers for reaeration: American Society of Civil Engineers Journal of the Environmental Engineering Division, v. 104, no. EE-2, p. 215-229.
Roberts, Sheila, 1987, The Sinks: Laramie, The Geological Survey of Wyoming, Wyoming Geo-Notes No. 13, p. 62-64.

Steele, T.D., Bauer, D.P., Wentz, D.A., and Warner, J.W., 1979, The Yampa River basin, Colorado and Wyoming-A preview to expanded coal-resource development and its impacts on regional water resources: U.S. Geological Survey Water-Resources Investigations Report 78-126, 133 p.

Tsivoglou, E.C., 1967, Tracer measurement of stream reaeration: Washington, D.C., Federal Water Pollution Control Administration [now, U.S. Environmental Protection Agency] report, $86 \mathrm{p}$.

Wilson, J.F., Jr., 1987, Time of travel, in Peterson, D.A., and others, Hydrology of Area 51, Northern Great Plains and Rocky Mountain coal provinces, Wyoming and Montana: U.S. Geological Survey Water-Resources Investigations Open-File Report 84-734, p. 36-37.

Wilson, J.F., Jr., Cobb, E.D., and Kilpatrick, F.A., 1986, Fluorometric procedures for dye tracing:

U.S. Geological Survey Techniques of Water-Resources Investigations, book 3 , chap. A12 (revised), $34 \mathrm{p}$.

Wyoming Department of Commerce, 1993, Sinks Canyon State Park: Park brochure.

Zimmerman, G.R., 1970, River time-of-travel as determined by fluorescent dye measurements and kinematic wave procedures: Laramie, University of Wyoming unpublished masters thesis, $104 \mathrm{p}$. 